\title{
FAIXAS E PERÍODOS DE CONTROLE DE PLANTAS DANINHAS E SEUS REFLEXOS NO CRESCIMENTO DO EUCALIPTO
}

\author{
ROBERTO ESTÊVÃO BRAGION DE TOLEDO
}

Tese apresentada à Escola Superior de Agricultura "Luiz de Queiroz", Universidade de São Paulo, para obtenção do título de Doutor em Agronomia, Área de Concentração: Fitotecnia.

\author{
PIRACICABA \\ Estado de São Paulo - Brasil \\ Maio - 2002
}




\title{
FAIXAS E PERÍODOS DE CONTROLE DE PLANTAS DANINHAS E SEUS REFLEXOS NO CRESCIMENTO DO EUCALIPTO
}

\author{
ROBERTO ESTÊVÃO BRAGION DE TOLEDO \\ Engenheiro Agrônomo
}

Orientador: Prof. Dr. RICARDO VICTORIA FILHO

Tese apresentada à Escola Superior de Agricultura "Luiz de Queiroz", Universidade de São Paulo, para obtenção do título de Doutor em Agronomia, Área de Concentração: Fitotecnia.

PIRACICABA

Estado de São Paulo - Brasil

Maio - 2002 


\section{Dados Internacionais de Catalogação na Publicação (CIP) DIVISÃO DE BIBLIOTECA E DOCUMENTAÇÃO - ESALQ/USP}

Toledo, Roberto Estevão Bragion de

Fa ixas e períodos de controle de plantas daninhas e seus reflexos no crescimento do euca lipto / Roberto Estevão Bragion de Toledo.-- Piracic aba, 2002.

$130 \mathrm{p}$.

Tese (Doutorado) - Escola Superior de Agricultura Luiz de Queiroz, 2002.

Bibliografia.

1. Capim braquiária 2. Competição de planta 3. Crescimento vegetal 4. Eucalipto 5 . Plantas daninhasl. Título

CDD 634.9734

"Permitida a cópia total ou parcial deste documento, desde que citada a fonte - $O$ autor" 


\section{DEDICO}

\section{A DEUS}

pela sua bondade divina.

\section{A minha esposa ÉRICA}

pelo amor, companheirismo, amizade e colaboração durante toda esta longa jornada.

Aos meus pais, Waldemar (in memorian) e Esther, que com muito amor confiaram no poder da educação para transformar nossas vidas.

Aos meus irmãos José Rogério (in memorian) e Fran, as minhas tias Wilma e Ely,

pelo apoio e carinho em todos os momentos de minha vida.

Aos meus sogros, Sr. Edevar e Sra. Maria de Lourdes, Aos meus cunhados, Mara, Olegário e Virgínia, por terem me acolhido na família Hernandes, pelo carinho e pela "torcida".

Aos pequenos, ítalo e Ivan, por serem exemplos de renovação.

Os quais sempre serão folhas amadas e valiosas na árvore da minha vida 


\section{AGRADECIMENTOS}

\section{Agradecer é o mínimo que posso fazer às seguintes pessoas e Instituições}

Ao Prof. Titular Ricardo Victoria Filho pela orientação, incentivo e principalmente por ter acreditado na realização desta pesquisa.

Ao CNPq e a CAPES, pelo auxílio àpesquisa.

A International Paper do Brasil Ltda, a Votorantim Celulose e Papel S.A.e a Hokko do Brasil Indústria Química e Agropecuária Ltda. por todo apoio logístico para que esta pesquisa fosse desenvolvida.

Aos Prof. Titular Robinson Antonio Pitelli, Prof. Dr. Pedro Luís da Costa Aguiar Alves, Prof. Dr. Pedro Jacob Christoffoleti, Prof . Dra. Maria do Carmo D. M. Pavani, Prof. Titular Julio Cezar Durigan e toda banca examinadora, pelos ensinamentos, pela colaboração que muito me auxiliaram na conclusão desta pesquisa.

Aos Departamentos de Produção Vegetal (ESALQ/USP) e de Biologia Aplicada à Agropecuária (FCAVJ/UNESP) e ao Núcleo de Estudos e Pesquisas Ambientais em Matologia (NEPEAM/FCAVJ/UNESP), por todo o apoio na condução desta pesquisa.

A bibliotecária Eliana M. Garcia pela revisão das Referências Bibliográficas.

A professora de inglês Marta pela revisão do summary.

Aos amigos e a todas as pessoas que, de alguma forma, contribuíram para a realização desta pesquisa.

Ao "Sítio do pica-pau-amarelo" - Pitoco, Paçoca, Bohêmia, Kami, Gaya, Gula, Sunny e outros que estão por vir...

Muito Obrigado. 


\section{SUMÁRIO}

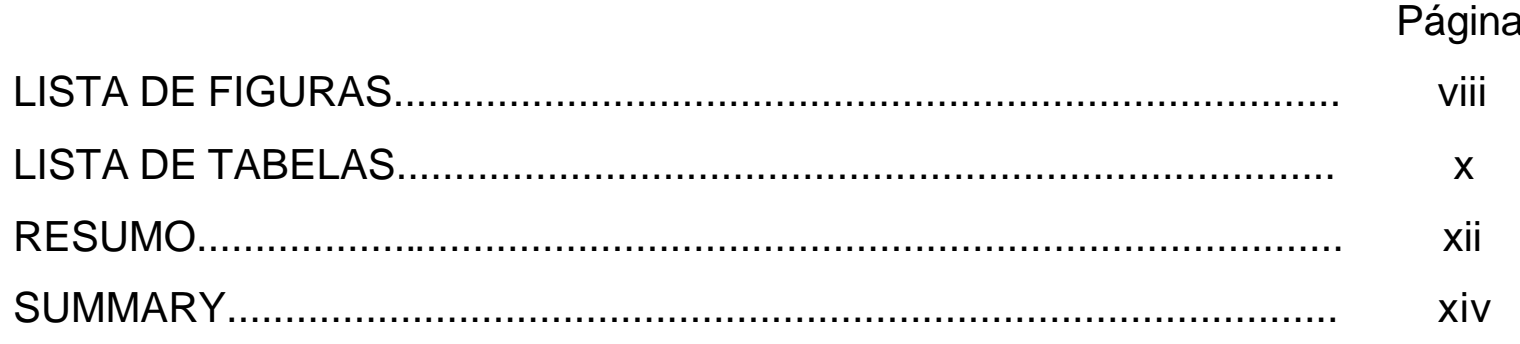

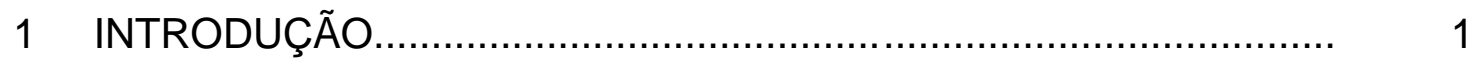

2 REVISÃO DE LITERATURA ............................................... 3

2.1 Importância do setor florestal no Brasil........................................ 3

2.2 Importância das plantas daninhas em áreas florestais...................... 5

2.3 Interferências das plantas daninhas em áreas florestais.................. 8



2.3.1.1Competição.................................................................. 9

2.3.1.1.1Competição por água................................................. 10

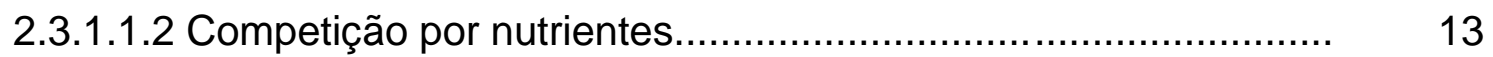

2.3.1.1.3 Interceptação de luz.................................................. 14

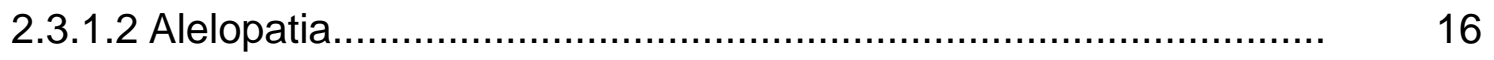

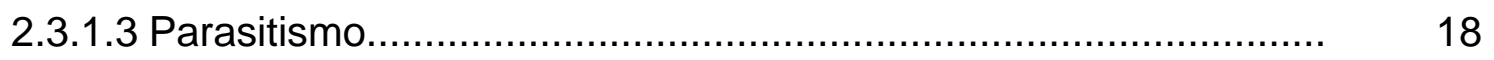

2.3.1.4 Depreciação da qualidade do produto florestal....................... 19

2.3.2 Interferências indiretas....................................................... 19

2.3.2.1 Danos físicos............................................................... 19

2.3.2.2 Hospedeiras intermediárias de pragas e doenças.................... 20 
2.3.2.3 Propagação de incêndios.

2.3.2.4 Lesões provocadas pelos métodos de controle das plantas daninhas.

2.3.2.5 Proteção de alguns inimigos naturais das espécies florestais...... 22

2.3.3 Interferências operacionais.......................................................... 23

2.4 Fatores que afetam o grau de interferência entre plantas daninhas e as espécies florestais.

2.4.1 Fatores ligados àcultura ........................................................... 25

2.4.2 Fatores ligados àcomunidade infestante..................................... 27

2.4.3 Fatores ligados ao ambiente....................................................... 30

2.4.4 Períodos de convivência e de controle das plantas daninhas......... $\quad 30$

2.5 Manejo de plantas daninhas em áreas florestais.............................. 34

2.5.1 Controle preventivo............................................................... 37

2.5.2 Controle cultural............................................................... 38

2.5.3 Controle biológico....................................................................... 38

2.5.4 Controle mecânico e físico.......................................................... 39

2.5.5 Controle químico .................................................................... 42

2.6 Questões futuras...........................................................................

3 FAIXAS DE CONTROLE DE PLANTAS DANINHAS E SEUS REFLEXOS NO CRESCIMENTO DO EUCALIPTO................................. 46

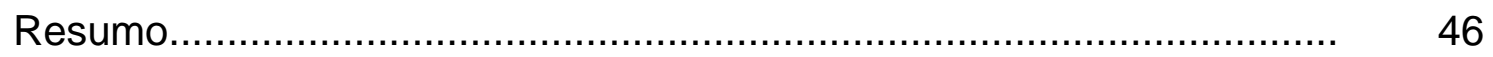

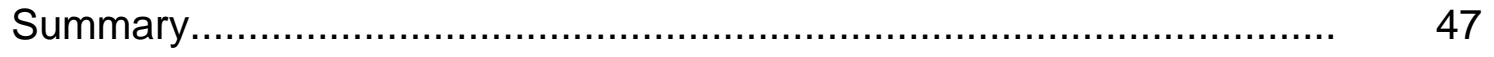

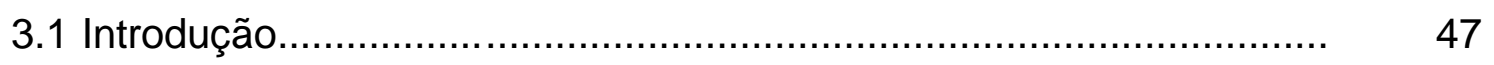

3.2 Material e Métodos................................................................... 49

3.3 Resultados e Discussão ............................................................. 54

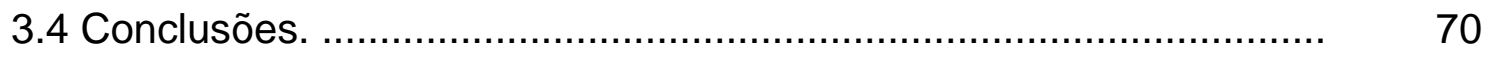

4 PERÍODOS DE CONTROLE DE PLANTAS DANINHAS E SEUS REFLEXOS NO CRESCIMENTO DO EUCALIPTO.............................. 73

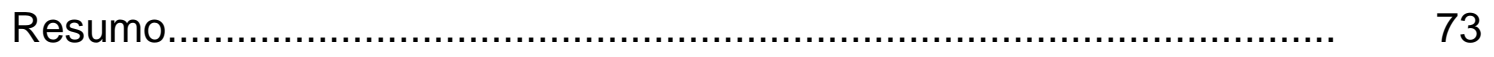

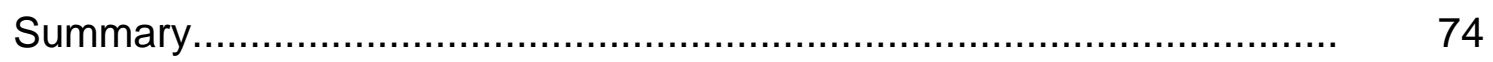

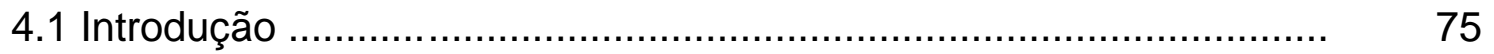


4.2 Material e Métodos............................................................................ 76

4.3 Resultados e Discussão.......................................................... 81

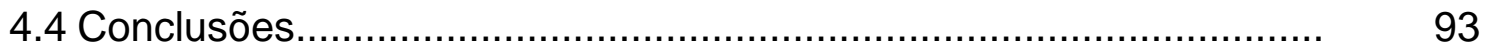

5 PERÍODOS DE CONTROLE DE Brachiaria sp E SEUS REFLEXOS NA PRODUTIVIDADE DO EUCALIPTO............................................ 98

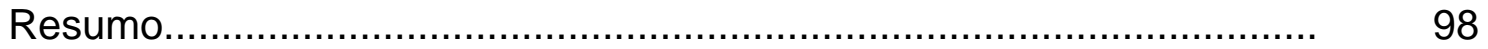

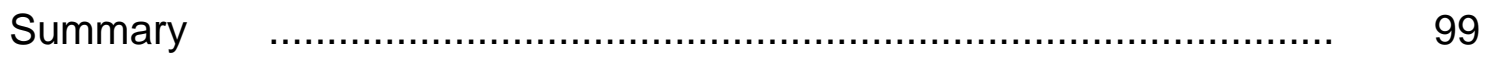

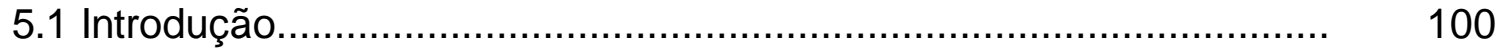

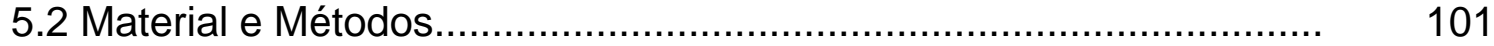

5.3 Resultados e Discussão.............................................................. 105



6 CONCLUSÕES GERAIS.......................................................... 118

REFERÊNCIAS BIBLIOGRÁFICAS................................................ 120 


\section{LISTA DE FIGURAS}

Página

1 Biomassa seca acumulada $\left(\mathrm{g} \cdot \mathrm{m}^{-2}\right)$ pelas principais populações de plantas daninhas na linha $(A)$, na entrelinha $(B)$ e na área total $(C)$ da cultura do eucalipto, em diferentes épocas de amostragens. Três Lagoas, MS

2 Densidade média (plantas. $\mathrm{m}^{-2}$ ) das principais populações de plantas daninhas na linha $(A)$, na entrelinha $(B)$ e na área total $(C)$ da cultura do eucalipto, em diferentes épocas de amostragens. Três Lagoas, M.S.......

3 Densidade média (plantas. $\mathrm{m}^{-2}-\mathrm{A}$ ) e biomassa média seca acumulada $\left(\mathrm{g} \cdot \mathrm{m}^{-2}\right.$ - B) pelas principais populações de plantas daninhas presentes na área experimental aos 364 dias após o plantio. Brotas, SP

4 Representação gráfica e matemática do modelo sigmoidal de Boltzmann utilizado no ajuste dos dados de altura, D.A.P., volume e I.M.A. de madeira das plantas de eucalipto sob diferentes períodos de controle das plantas daninhas

5 Densidade média (plantas. $\mathrm{m}^{-2}$ ) e biomassa seca acumulada $\left(\mathrm{g} \cdot \mathrm{m}^{-2}\right.$ ) do capim-braquiária em relação à comunidade infestante presente nas parcelas nas quais as plantas de eucalipto conviveram com a comunidade infestante por 364 dias após o plantio. Três Lagoas, MS..... 
6 Densidade média (plantas $/ \mathrm{m}^{-2}$ ) e biomassa média seca acumulada $\left(\mathrm{g} \cdot \mathrm{m}^{-2}\right)$ das principais espécies de plantas daninhas presentes nas parcelas nas quais as plantas de eucalipto conviveram com a comunidade infestante por 364 dias após o plantio. Brotas, SP

7 Representação gráfica e matemática do modelo sigmoidal de Boltzmann utilizado no ajuste dos dados de altura, D.A.P., volume e I.M.A. de madeira das plantas de eucalipto sob diferentes períodos de controle das plantas daninhas.

8 Biomassa média seca acumulada $\left(\mathrm{g} \cdot \mathrm{m}^{-2}\right)$ das principais espécies de plantas daninhas presentes nas parcelas nas quais as plantas de eucalipto conviveram com a comunidade infestante por 364 dias após o plantio. 


\section{LISTA DE TABELAS}

Página

1 Variações da largura da faixa de controle das plantas daninhas durante os meses de agosto a julho que constituíram os tratamentos experimentais. Três Lagoas, M.S e Brotas, SP.

2 Descrição dos contrastes ortogonais de interesse, utilizados nos ensaios de faixas de controle das plantas daninhas e seus reflexos na produtividade do eucalipto. Três Lagoas, MS e Brotas, SP.

3 Efeito das faixas de controle do capim-braquiária sobre a variação relativa (\%) em relação àtestemunha "no limpo" em D.A.P., altura, volume e I.M.A. de madeira das plantas de eucalipto. Três Lagoas, M.S

4 Efeito das faixas de controle das plantas daninhas sobre a porcentagem de redução média em altura, D.A.P., volume em I.M.A. de madeira das plantas de eucalipto. Brotas, SP.

5 Valores de $\mathrm{F}$ dos contrastes de interesse em relação àaltura e o D.A.P. das plantas de eucalipto. Três Lagoas, MS. e Brotas, SP

6 Efeito das faixas de controle do capim-braquiária sobre a altura, o D.A.P., volume e I.M.A. médio de madeira de plantas de eucalipto. Três Lagoas, MS 
7 Efeito das faixas de controle das plantas daninhas sobre a altura, o D.A.P., volume e I.M.A. de madeira de plantas de eucalipto. Brotas, SP................... 72

8 Descrição dos tratamentos experimentais. Três Lagoas, MS e Brotas, SP......... 79

9 Variação o período total de prevenção à interferência em função das porcentagens de redução em altura, D.A.P., volume e I.M.A. de madeira das plantas de eucalipto. Três Lagoas, MS e Brotas, SP

10 Efeito dos períodos de convivência e de controle das plantas daninhas sobre altura e D.A.P. de plantas de eucalipto. Três Lagoas, MS

11 Efeito dos períodos de convivência e de controle das plantas daninhas sobre o volume e I.M.A. de plantas de eucalipto. Três Lagoas, MS.

12 Efeito dos períodos de convivência e de controle das plantas daninhas sobre a altura e D.A.P. de plantas de eucalipto. Brotas, SP

13 Descrição dos tratamentos experimentais. Piratininga, SP.

14 Plantas daninhas mais comuns que ocorreram na área de Piratininga, SP

15 Variação do período total de prevenção à interferência em função das porcentagens de redução em altura, D.A.P., volume de madeira e I.M.A. das plantas de eucalipto toleradas.

16 Efeito dos períodos de controle das plantas daninhas sobre a altura, D.A.P. e volume de madeira de plantas de eucalipto.

17 Efeito dos períodos de controle das plantas daninhas sobre o volume $\left(\mathrm{m}^{3}\right.$.há $\left.{ }^{-1}\right)$ e incremento médio anual de madeira $\left(\mathrm{m}^{3} \cdot \mathrm{ha}^{-1} \cdot \mathrm{ano}^{-1}\right)$ de plantas de eucalipto 


\title{
FAIXAS E PERÍODOS DE CONTROLE DE PLANTAS DANINHAS E SEUS REFLEXOS NO CRESCIMENTO DO EUCALIPTO
}

\author{
Autor: ROBERTO ESTÊVÃO BRAGION DE TOLEDO \\ Orientador: Prof. Dr. RICARDO VICTORIA FILHO
}

\section{RESUMO}

Com o objetivo de avaliar os efeitos das faixas de controle das plantas daninhas sobre o crescimento do eucalipto foram conduzidos dois ensaios localizados nos municípios de Três Lagoas, MS (julho de 1996 a agosto de 2000) e de Brotas, SP (fevereiro de 1997 a março de 2001). Os tratamentos experimentais destes ensaios constaram de dois grupos: (i) grupo I: faixas fixas de controle durante os 12 meses iniciais, a: 0, 25, 50, 100, 125 e $150 \mathrm{~cm}$ de cada lado da linha de plantio do eucalipto; e, (ii) grupo II faixas crescentes de controle, a: 25 a 150, 25-50-150, 50-125-150, 100-125-150, 100 a 150 e 125 a $150 \mathrm{~cm}$. Aos 49 meses após o plantio dessas áreas, foi constatado que as plantas de eucalipto que cresceram nas parcelas com faixas de controle fixas iguais a $100 \mathrm{~cm}$ ou crescentes superiores a $50 \mathrm{~cm}$ nos três primeiros meses, respectivamente, mostraram-se superiores, em diâmetro medido à altura do peito (D.A.P.), altura, volume e incremento médio anual de madeira (I.M.A.). Já com o objetivo de estudar os efeitos dos períodos de controle das plantas daninhas sobre a 
produtividade do eucalipto foram conduzidos três ensaios localizados nos municípios de Três Lagoas, MS (janeiro de 1997 a março de 2001), Brotas, SP (fevereiro de 1997 a fevereiro de 2001) e Piratininga, SP (agosto de 1991 a maio de 1999). Nos ensaios de Três Lagoas, MS e Brotas, SP, os tratamentos consistiram de diferentes períodos de convivência e de controle das plantas daninhas na cultura divididos em dois grupos. No primeiro, a convivência iniciava no plantio e estendia até $28,56,84,112,140,168,252$ e 364 dias. No segundo, a convivência iniciava aos $0,28,56,84,112,140,168$ e 252 dias e estendia até os 364 dias. Para Três Lagoas, MS, o período total de prevenção à interferência (PTPI) foi de 180 e 210 dias, quando se considera a redução de 5 e $2 \%$ no volume de madeira aos 50 meses após o plantio, respectivamente. No entanto, para Brotas, SP, o PTPI foi de 60 dias, considerando-se $5 \%$ de redução em volume de madeira aos 24 meses após o plantio. Todavia, pode-se questionar o efeito da interferência das plantas daninhas distribuídas irregularmente na área de Brotas, SP e sugerir a hipótese de recuperação das plantas de eucalipto a partir de 48 meses, bem como o potencial alelopático dos restos culturais do eucalipto. Em Piratininga, SP, os tratamentos consistiram de diferentes períodos de convivência e de controle das plantas daninhas na cultura do eucalipto divididos em dois grupos. No primeiro, a convivência iniciava no plantio e era estendida até 28,56 , 84, 112, 140, 168, 278 e 360 dias. No segundo, a œnvivência iniciava aos 0, 28, $56,84,112,140,168$ e 278 dias e era estendida até 364 dias. O PTPI foi de 79 dias quando se analisa o volume de madeira $\left(\mathrm{m}^{3} \cdot \mathrm{ha}^{-1}\right)$ aos 78 meses após o plantio (colheita da cultura).

PALAVRAS CHAVE: Brachiaria decumbens, eucalipto, manejo de plantas daninhas, competição e interferência. 


\title{
THE WEED CONTROL STRIP IN ROWS AND THE WEED CONTROL PERIODS AND ITS EFFECTS AT THE EUCALYPTUS GROWTH
}

\author{
Author: ROBERTO ESTÊVÃO BRAGION DE TOLEDO \\ Adviser: Prof. Dr. RICARDO VICTORIA FILHO
}

\section{SUMMARY}

This research has been carried out in areas of Eucalyptus $\mathrm{sp}$ in Três Lagoas, Mato Grosso do Sul State, Brazil (from July 1996 through August 2001) and Brotas, São Paulo State, Brazil (from February 1997 through March 2001), to evaluate the effects of weed control strip variations at the Eucalyptus growth. The experiments consisted of two treatments: group 1 - with constant width control strips have been kept throughout the first 12 months, i.e., at 0, 25, 50, 100, 125 and $150 \mathrm{~cm}$ on both sides of the Eucalyptus row and, group 2: with an increasing of the width control strips has been adopted along the experimental period, i.e., at 25 to $150,25-50-150,50$ at $150,50-125-150,100-125-150,100$ to 150 and 125 to $150 \mathrm{~cm}$ on both sides of the Eucalyptus row. After 49 months that areas were planted it was checked that the Eucalyptus plants that had grown as in the constant and as in increasing width control strips, equal to or higher than 100 and $50 \mathrm{~cm}$, respectively has showed a higher diameter, height plant, volume and annual average increment of the wood. These results have led to the conclusion that the control minimum strip width should be $100 \mathrm{~cm}$ on the both sides of the Eucalyptus row in order to keep it the weed interference. This research has been 
carried out in Três Lagoas, Mato Grosso do Sul State, Brazil (from January 1997 through March 2001) and Brotas, São Paulo State, Brazil (from February 1997 through 2001) and Piratininga, São Paulo State, Brazil (from August 1991 through May 1999), with the purpose study of a studying about the effects of the weed interference at the Eucalyptus sp growth. In Três Lagoas and in Brotas the treatments have consisted of in the different extensions and the different time limits of the weed control periods. The weed control periods have been divided in to two groups. At the first one, the weed control periods have been since the Eucalyptus plantation to $28,56,112,140,168,224,252$ and 364 days. At the second group, the weed control period has begun at $0,28,56,112,140,168,224$ and 252 days after the plantation and has finished at the end of the 364 days. To assure the crop productivity in Três Lagoas it was necessary to keep a weed control period in a range of 180 and 210 days after plantation, in that case it should consider a reduction of $5 \%$ at the wood volume in the 50 months after the plantation. However, in Brotas area it was necessary to keep the weed control plantation in a range of 60 days of to consider the wood volume throughout 24 months after the plantation. However, it might ask about question the effects of the weed interference in a case of a low density and in a weed irregular distribution in that area, suggesting improvement at the quality of the Eucalyptus plants in a range of 48 months after the plantation the allelophatic potential from the Eucalyptus mulching as well. In Piratininga the treatments have consisted of different extensions and time limits of the weed control periods. The weed control periods has been since the Eucalyptus plantation to 28, 56, 112, 140, 168, 224, 278 and 360 days. At the second group the weed control period has begun in a range of 0 , $28,56,112,140,168,224$ throughout 278 days after the plantation and has finished at the end of the 364 days. It has been necessary to keep a weed control period in a range of 79 days after the plantation throughout 78 months, in that case it should consider reduction of $5 \%$ at the wood volume.

KEY WORDS: Brachiaria decumbens, silviculture, weed managemet, competition and interference. 


\section{INTRODUÇÃO}

A atividade florestal brasileira participa com $4 \%$ do produto interno bruto (PIB), proporcionando milhões de empregos e é considerada uma das principais atividades para responder aos desafios da exportação. No entanto, a participação do Brasil no mercado internacional de produtos florestais é insignificante (2\%), à exceção da celulose de eucalipto com $47 \%$ do mercado mundial (SBS, 2001).

A produtividade das plantações florestais brasileiras está aquém de seu potencial, havendo amplas possibilidades de elevá-la, adotando-se manejo florestal adequado. $O$ grande desafio consiste em identificar o equilíbrio entre as práticas silviculturais que mantenham ou elevem a produtividade a longo prazo, reduzindo os impactos ambientais (Gonçalves et al., 2000).

$O$ desenvolvimento de pesquisas que visem solucionar ou minimizar a ocorrência de problemas operacionais representa o primeiro passo para a evolução da atividade florestal brasileira (Benedetti, 2000).

Nas últimas décadas, os pesquisadores vêm estudando os efeitos da interferência das plantas daninhas sobre o crescimento e a produtividade do eucalipto (Pitelli, 1987; Pitelli \& Marchi, 1991; Bezutte et al., 1993; Bezutte et al., 1995; Dinardo, 1996; Marchi, 1996; Toledo et al., 1996; Toledo, 1998; Dinardo et al.., 1998; Alves et al., 1999; Costa, 1999; Silva, 1999; Toledo et al., 2000 abc). Dentre os efeitos dessa interferência, pode-se destacar a competição por água e nutrientes, interceptação de luz e a interferência de natureza alelopática e o aumento de riscos de incêndios. Além desses fatores, há também, o aumento 
progressivo nos custos da mão-de-obra necessária para as operações de limpeza e manutenção da floresta (Toledo, 1999). Segundo Pitelli \& Marchi (1991), a interferência imposta pelas plantas daninhas é mais severa principalmente na fase inicial de crescimento, ou seja, do plantio até cerca de um ano de idade das plantas de eucalipto. Conclusões dessas e outras pesquisas e constatações práticas, demonstram a significativa importância do manejo destas plantas para o sucesso dos empreendimentos florestais.

O manejo da comunidade infestante em áreas florestais, com o controle em faixas (Toledo, 1998 e Silva, 1999) ou pela manutenção da cultura em períodos de ausência de competição com as plantas daninhas (Pitelli et al., 1988; Marchi, 1996 e Toledo, 1998), é realizado com métodos mecânicos e químicos (Toledo, 1999). Dentre os herbicidas aplicados na cultura do eucalipto, destacam-se o oxyfluorfen e o glyphosate, sendo o último utilizado em grande escala, pelo fato de ser aplicado em pós-emergência das plantas daninhas, facilitando assim o manejo em áreas de cultivo mínimo de modo a assegurar pleno potencial produtivo do eucalipto minimizando o custo de produção e o impacto ambiental.

A presente pesquisa teve por objetivo estudar os efeitos das faixas e dos períodos de controle das plantas daninhas e seus reflexos na produtividade de Eucalyptus grandis W. Hill ex Maiden x Eucalyptus urophylla S.T. Blake nos municípios de Três Lagoas, MS e Brotas, SP e de Eucalytus grandis W. Hill ex Maiden no município de Piratininga, SP. 


\section{REVISÃO DE LITERATURA}

\subsection{Importância do setor florestal no Brasil}

As plantações florestais brasileiras, em sua maioria (70\%) são pertencentes a empreendimentos verticalizados e os $30 \%$ restantes pertencem a produtores independentes. O consumo de madeira em toras provenientes de plantações florestais de Eucalyptus e de Pinus no Brasil é de 102 milhões $\mathrm{m}^{3}$.ano ${ }^{-1}$, sendo o incremento médio anual de plantio de 170 a 200 mil ha.ano $^{-1}$ (70\% de áreas de reforma e 30\% de novas áreas de plantio). Segundo o Programa Nacional de Florestas (PNF) é necessário o plantio de 630 mil ha.ano-1, para atender a demanda de madeira dos vários segmentos industriais e para energia (SBS, 2001).

Atualmente 4,805 milhões de hectares plantados com eucalipto e pinus constituem a base do setor florestal no Brasil. No Programa Nacional de Florestas estão previstos incrementos médios anuais de 622 mil hectares, sendo estes distribuídos em 170 mil ha.ano ${ }^{-1}$ para o setor de celulose e papel, 250 mil ha.ano-1 para a produção de carvão vegetal, 130 mil ha.ano ${ }^{-1}$ para a produção de madeira sólida e 72 mil ha.ano $^{-1}$ para obtenção de lenha. Em 1998, a demanda de madeira em toras de florestas nativas no país era de aproximadamente 108 milhões de metros cúbicos, sendo que a produção de celulose e papel e de carvão foram responsáveis pelo consumo de 64 milhões de metros cúbicos de toras de eucalipto e pinus (Garlipp, 2000). 
As espécies mais utilizadas no programa de plantio florestal são Eucalyptus spp (E. saligna, E. urophylla, E. citriodora, E. grandis e alguns híbridos), Pinus spp. subtropicais ( $P$. elliotti, $P$. taeda e $P$. patula) e Pinus tropicais ( $P$. caribaea, $P$. oocarpa e $P$. hondurensis). Outras espécies com áreas florestadas relevantes são Auraucaria angustifolia, Hevea brasiliensis, Acacia mearnsii, Tectona grandis e Gmelina arbórea (Garlipp, 2000).

Segundo Garlipp (2000), estima-se que anualmente são cortados cerca de 246 milhões de metros cúbicos de madeira, sendo 56\% deste montante (137,8 milhões de $\mathrm{m}^{3}$ ) proveniente de floresta nativa e 44\% (108,2 milhões de $\mathrm{m}^{3}$ ) de florestas plantadas. Estima-se que 73 milhões de $\mathrm{m}^{3}$ são destinados ao uso industrial, 52 milhões de $\mathrm{m}^{3}$ são utilizados como carvão vegetal e 121 milhões de $\mathrm{m}^{3}$ são usados como lenha, o que equivale a 17,6 milhões de $\mathrm{m}^{3}$ de madeira serrada, 4,3 milhões de $\mathrm{m}^{3}$ de chapas, compensados, aglomerados, e 6,5 milhões de toneladas de celulose.

Apesar dessa magnitude, deve-se salientar que, para garantir sua sustentabilidade e competitividade, o setor florestal depende, dentre outros fatores, de uma base florestal que atenda a padrões cada vez mais exigentes em termos de qualidade e produtividade, reduzindo o impacto ambiental, o que conduz ao efetivo investimento em pesquisa e adoção de práticas silviculturais adequadas (Toledo, 1999).

Entende-se por formação de uma floresta artificial, o período compreendido entre o plantio da muda no local definitivo até o momento em que estas plantas passam a dominar a vegetação espontânea do local (Ferreira, 1977). Através desta definição fica claro que qualquer medida de manejo das plantas daninhas, com o objetivo de favorecer o desenvolvimento das plantas florestais é importante para o sucesso na implantação de florestas tropicais (Christoffoleti et al., 1998). 


\subsection{Importância das plantas daninhas}

As culturas florestais, como qualquer população natural, estão sujeitas a uma série de fatores ecológicos que, direta ou indiretamente, podem afetar o crescimento das árvores e conseqüentemente a produção de madeira, carvão e celulose. Didaticamente, estes fatores podem ser divididos em fatores abióticos e bióticos. São considerados abióticos aqueles decorrentes da ação dos fatores físicos ou químicos do ambiente, como a disponibilidade de água e nutrientes do solo, pH do solo, luminosidade e outros. Os bióticos são aqueles decorrentes da ação dos seres vivos, como a competição, a predação e outros (Pitelli \& Marchi, 1991).

A presença da comunidade infestante no ecossistema florestal, ou seja, em um ambiente sob perturbação, condiciona a ação (ou provoca mudança na intensidade de atuação) de inúmeros fatores ecológicos, alguns favoráveis e outros desfavoráveis ao interesse das empresas florestais (Alves, 1992).

As plantas infestantes aumentam a diversidade biótica do primeiro nível trófico desse ecossistema, incrementando assim, as possibilidades de equilíbrio ecológico local, refletindo nas populações de predadores e parasitas florestais; também aumentam a proteção da superfície do solo contra o processo erosivo; além disso, imobilizam grandes quantidades de nutrientes que seriam carregados pela erosão ou pela lixiviação (Marchi, 1989).

$\mathrm{Na}$ realidade, as plantas que infestam as áreas florestais, são plantas com características pioneiras que ocupam locais nos quais, por qualquer motivo, a cobertura natural foi extinta e o solo tornou-se total ou parcialmente exposto. Esta vegetação, sempre existiu e já foi muito importante na recuperação de extensas áreas onde a vegetação original foi extinta por um processo natural, como ocorreu na deglaciação do pleistoceno (Pitelli \& Karam, 1988).

As plantas com características pioneiras possuem normalmente grande agressividade caracterizada por elevada e prolongada capacidade de produção de diásporos dotados de alta viabilidade e longevidade, que são capazes de 
germinar, de maneira descontínua, em muitos ambientes e com adaptações especiais para a disseminação a curta e longa distância. Estas plantas apresentam rápido crescimento vegetativo e florescimento, são autocompatíveis mas não completamente autógamas ou apomíticas e, quando alógamas utilizam diversos agentes de polinização (vento, água e outros): quando perenes, além de vigorosa reprodução vegetativa e de regeneração de fragmentos, estas plantas devem ser bastante frágeis, de modo que possam ser facilmente arrancadas do solo. Além disso, essas plantas desenvolvem mecanismos especiais que dotam de maior capacidade de competição pela sobrevivência, como alelopatia, hábito trepador e outras. Resumindo, a perpetuação de uma espécie vegetal como infestante de áreas florestais, está condicionada a um compromisso entre a plasticidade de cada indivíduo e àqueles processos de longo prazo que the outorgam flexibilidade adaptativa, frente as eventuais modificações que ocorrem em condições naturais em todo o ecossistema, através do tempo (Pitelli, 1987).

Um conceito de planta daninha aplicado às atividades florestais é exaltado na definição proposta por Blanco (1972), que define como planta daninha: "toda e qualquer planta que germine espontaneamente em áreas de interesse humano e que, de alguma forma, interfira prejudicialmente nas atividades agrícolas".

As plantas daninhas são consideradas o maior problema mundial em termos de danos na produção agrícola, custando, apenas nos Estados Unidos da América do Norte, um valor anual estimado em 16 bilhões de dólares, considerando-se as perdas de produção e os custos envolvidos no controle. Esta importância aumenta aproximadamente para 21 bilhões de dólares quando se incluem os custos com plantas daninhas em pastagens, florestas e ecossistemas aquáticos (Charudattan \& Pitelli, 1993).

No Brasil, Toledo et al. (1996) constataram que a atividade mais onerosa no primeiro ano de implantação de E. grandis é o controle das plantas daninhas. Nesta pesquisa, o controle do capim-braquiária na entre linha de plantio com quatro capinas manuais representou $30,7 \%$ dos custos totais de implantação, 
enquanto que o controle químico com glyphosate em três ocasiões representou $17,3 \%$ do total gasto. Esses autores ainda observaram que, de maneira geral, os custos de controle das plantas daninhas totalizaram cerca de $66 \%$ do custo total de implantação da floresta, independente do manejo adotado.

A interferência de plantas daninhas tem sido o grande problema na implantação e manutenção de florestas de Eucalyptus sp e Pinus sp, o que pode ser confirmado por alguns estudos que demonstram que essas plantas causam prejuízos ao crescimento e a produtividade, a medida que estas competem por luz, nutrientes, água e "nicho ecológico"; exercem pressão de natureza alelopática; aumentam riscos de incêndios e outros, justificando, plenamente, a preocupação com seu controle (Pitelli, 1987 e Pitelli \& Marchi, 1991). Além desses fatores, depara-se também com o aumento progressivo nos custos da mão-de-obra necessária para as operações de limpeza e manutenção desses plantios (IPEF, 1976; Toledo et al., 1996).

Existem poucos trabalhos na literatura, destacando a importância da interferência das plantas daninhas em áreas de implantação de povoamentos florestais (Christoffoleti et al., 1998). Segundo Kreiijc \& Lourenço ${ }^{1}$, citado por Christoffoleti et al. (1998), ao se pensar em um programa de controle de plantas daninhas em áreas florestais, é importante saber em que época elas representam o maior grau de competição com a cultura e determinar o método mais apropriado para a execução do controle. O controle tardio, após a competição já estabelecida, implica no aumento da porcentagem de falhas e de árvores dominadas, o que afeta significativamente a produtividade final das florestas.

Segundo Porcile et al. (1995), cada região apresenta características definidas de topografia, solo e inclusive microclimas particulares que determinam formações vegetais diferenciadas.

${ }^{1}$ KREIICI, L.C.; LOURENÇO, P.Y. Utilização de herbicidas na área florestal da COPENER. In: CHRISTOFFOLETI, P.J.; BRANCO, E.F.; COELHO, J.V.G. BRITVA, M.; GIMENES FILHO, B. Controle de plantas daninhas em Pinus taeda através do herbicida imazapyr. Circular Técnica n. $187,1998,11 \mathrm{p}$. 
A atividade agrícola e a pecuária intensiva alteram a cobertura vegetal nativa e numerosas espécies vegetais aumentam sua população, constituindo-se em plantas daninhas. Estas alcançam lugares com uma elevada agressividade, interferindo na implantação e no desenvolvimento dos cultivos florestais como é o caso da Brachiaria decumbens Stapf (Porcile et al., 1995).

A diversidade da comunidade infestante em áreas florestais comerciais está, intimamente associada ao histórico da área destinada a tal prática. Em áreas de cerrado, provavelmente a maior interferência das plantas daninhas seja causada por rebrotas de plantas que naturalmente habitavam esta área, ao passo que em áreas anteriormente ocupadas por pastagens, o maior problema será com espécies de gramíneas forrageiras que anteriormente ocupavam o local, como as plantas dos gêneros Brachiaria sp. e Panicum sp. (Toledo, 1998).

\subsection{Interferência das plantas daninhas em áreas florestais}

De acordo com Harper (1977), a interferência é o efeito adverso que uma planta pode exercer sobre o crescimento e desenvolvimento de outras que se encontram próximas. Poucos são os estudos que separam os componentes da interferência, devido àcomplexidade desse fenômeno ecológico (Alves, 1992).

O termo interferência refere-se ao conjunto de ações que recebe uma determinada cultura ou atividade do homem, em decorrência da presença das plantas daninhas num determinado ambiente (Harper, 1977).

A interferência da comunidade infestante em áreas florestais pode ser didaticamente dividida em três grupos: interferências diretas, interferências indiretas e interferências operacionais (Pitelli \& Marchi, 1991).

É importante ressaltar que os sintomas da interferência variam desde respostas óbvias de germinação e mortalidade, æ̀ mais sutis respostas plásticas como redução no tamanho, peso e número de órgãos. Enquanto alguns estudos de interferência revelam redução no acúmulo de matéria seca ou produção, outros mostram sintomas característicos que se desenvolveram devido as condições 
limitantes de nutrientes ou a presença de compostos químicos tóxicos. No entanto, relatos de sintomas típicos de interferência são relativamente raros. É possível que estes sintomas sejam menos notáveis quando a planta é sujeita repentinamente a um estresse severo (Fuerst \& Putnam, 1983).

\subsubsection{Interferências diretas}

Dentre as interferências diretas sobre as espécies florestais destacam-se a interferência competitiva, que é a redução de um ou mais recursos limitantes, como a água e os nutrientes, a interceptação da luz; e a interferência alelopática, que é a produção e a liberação de compostos químicos por tecidos vivos ou em decomposição, que interferem no crescimento de plantas próximas (Toledo, 1998).

\subsubsection{Competição}

A competição entre plantas é parte fundamental na ecologia dos vegetais. A palavra competição é oriunda do latim "competere" que significa pedir ou lutar por alguma coisa que alguém também esteja requisitando. A literatura é rica em estudos de competição que quantificam os efeitos de uma espécie vegetal sobre a outra; no entanto, nenhum deles explica a competição e os mecanismos pelos quais ela ocorre. Existem referências sobre a competição das plantas daninhas com as cultivadas desde épocas muito remotas (Christoffoleti \& Passini, 2000).

Diversos autores sugerem que a principal forma de interferência da comunidade infestante sobre as plantas florestais, é a competição pelos recursos essenciais ao crescimento e desenvolvimento das árvores. Os recursos mais freqüentes e passíveis de competição são: a água, os nutrientes, a interceptação da luz e o "nicho ecológico", sendo que só se estabelecerá a competição quando um desses recursos não for suficiente para suprir as necessidades das plantas que habitam o mesmo ambiente, limitando, assim, o desenvolvimento das plantas envolvidas no processo (Donald, 1963; Pitelli et al., 1988; Pitelli \& Marchi, 1991; Toledo, 1998). 
A formação de plantações florestais de eucalipto com a finalidade de produção de madeira industrial requer bom preparo de solo e eficiente controle da comunidade infestante pelo menos na fase inicial de crescimento da cultura, ou seja, do plantio até cerca de um ano de idade das plantas de eucalipto, devido a elevada sensibilidade destas à competição imposta pelas plantas daninhas (Wietchetek, 1988; Simões, 1989; Pitelli \& Marchi, 1991; Kogan, 1992; Lima, 1996; Toledo, 1998). Após essa fase inicial, o eucalipto estará bem estabelecido no ambiente e o fechamento das copas praticamente impedirá o crescimento das plantas daninhas, fazendo com que a cultura passe a dominar a concorrência da vegetação espontânea (Simões, 1989; Lima, 1996). No entanto, em algumas plantações brasileiras, o desenvolvimento da floresta é mais lento e a penetração de luz é suficiente para permitir o crescimento intenso de gramíneas e plantas nativas, formando assim sub-bosques que permitem a consorciação do eucalipto com o gado (Lima, 1996).

Marchi (1989) e Dinardo (1996) relatam que as plantas de eucalipto, na fase inicial de desenvolvimento são bastante afetadas pela interferência imposta pelas plantas de capim-braquiária (B. decumbens).

\subsection{Competição por água}

Kozlowski ${ }^{2}$, citado por Ferreira (1977), afirma ser a disponibilidade de água a maior responsável pela sobrevivência e desenvolvimento das plantas arbóreas sobre qualquer outro fator. Outro autor citado é $\mathrm{Ursic}^{3}$, que demonstrou a queda da disponibilidade de água para Pinus taeda em áreas onde vegetava a gramínea Andropogon seoparius.

2 KOZLOWSKI, T.T. Growth and Development of trees. I. Seed germination ontogeny, and shoot growth. In: FERREIRA, J.E.F. Herbicidas em Florestas, 1977. Piracicaba. IPEF/ESALQ/USP. 1977. Boletim informativo 05, p. 262-341.

${ }^{3}$ URSIC, S.J. Tolerance of loblolly pine seedlings to soil moisture stress. In; FERREIRA, J.E.F. Herbicidas em Florestas, 1977. Piracicaba. 
Larson \& Schubert ${ }^{4}$ citados por Ferreira (1977), ponderaram que a umidade do solo é o fator de competição mais importante entre gramíneas e o Pinus ponderosa, devido ao fato das raízes das gramíneas se desenvolverem mais cedo e serem capazes de levar o nível de umidade do solo a níveis mais baixos, do que aqueles em que o Pinus tem condições de absorção.

Sands \& Nambiar (1984) ponderam que o estresse hídrico severo e a grande redução na produtividade podem ser esperados se a comunidade infestante não for controlada em áreas de plantio de Pinus radiata, particularmente em árvores mais jovens. Os autores inferem ainda que o estresse hídrico induzido pela competição torna-se progressivamente menor a partir do sétimo mês após o plantio das mudas.

Carter et al. (1984), estudando os efeitos da competição imposta pela comunidade infestante em Pinus taeda, verificaram que a eliminação de todas as plantas infestantes num raio de $1,5 \mathrm{~m}$ ao redor do caule das plantas de Pinus taeda reduziu significativamente o estresse hídrico quando comparado com o tratamento sem a eliminação. Zutter et al. (1986) verificaram que o efeito de vários níveis de vegetação herbácea no crescimento de plantas jovens de Pinus taeda foi atribuído, em parte, æ̀ diferenças de umidade do solo e seus efeitos no balanço hídrico das plantas e nos processos fisiológicos. Os autores comentam ainda, que, no primeiro ano, houve relação entre o crescimento das mudas e o nível de umidade do solo no mês de agosto, período na qual a umidade do solo apresentou-se em níveis mais baixos do que as outras épocas.

Em estudo sobre a influência de níveis de água no desenvolvimento de $E$. grandis e E. citriodora na presença de Brachiaria brizantha realizado em condições de casa-de-vegetação, Silva et al.. (1995) observaram redução na capacidade de utilização da água das duas espécies de eucalipto quando conviveram com o capim-braquiarão, apesar de serem eficientes na absorção de água quando cresceram livres da interferência desta planta daninha.

\footnotetext{
${ }^{4}$ LARSON, L.; SCHUBERT, K. 1969. In: FERREIRA, J.E.F. Herbicidas em Florestas. 1977.
} 
No município de João Pinheiro, MG, Pitelli et al.. (1988) demostraram que os efeitos da interferência da comunidade infestante durante o primeiro ano do crescimento de Eucalyptus pellita foram mais drásticos durante o período de abril a setembro, quando ocorreu severa restrição hídrica na região.

Segundo Davies (1987), as plantas daninhas não só diminuem a disponibilidade de água no solo por incremento na evapotranspiração, como também interceptam parte da chuva, retendo-a acima da superfície do solo, fazendo com que a água penetre no mesófilo foliar destas plantas ou evapore. $\mathrm{O}$ autor infere que a competição por água em árvores de bordo (Acer saccharinum) incrementa a resistência estomática das folhas tanto em áreas irrigadas como naquelas sem irrigação, quando comparado com plantas crescendo livre das plantas daninhas.

De modo geral, o sistema radicular das plantas cresce muito mais rapidamente que àparte áerea; sendo assim, a competição por água e nutrientes sempre começa antes que a competição por luz (interceptação da luz). O volume relativo de solo ocupado pelo sistema radicular determina a capacidade competitiva de uma planta por água e nutrientes no solo. Plantas com sistema radicular mais desenvolvido ganham a competição mais facilmente, principalmente quando o sistema radicular das plantas encontra-se entrelaçados no solo e a planta cultivada e a planta daninha tentam explorar a água no mesmo volume de solo. A competição é menos intensa se as raízes das plantas exploram volumes diferentes de solos, como uma planta com intenso sistema radicular fasciculado competindo com uma planta que apresenta sistema radicular de mesmo comprimento, aquela que tem um sistema radicular mais aberto ou esparramado e menos ramificado é a que ganha a competição (Christoffoleti et al., 1998).

\subsection{Competição por nutrientes}


As árvores que crescem sob a interferência das plantas daninhas podem apresentar deficiências de alguns nutrientes. Esta deficiência na maioria das vezes é resultado da competição pelos nutrientes imposta pela comunidade infestante (Marchi et al., 1995).

Davies (1987), verificou os decréscimos nos teores de nitrogênio, fósforo e potássio em folhas de Pinus serotina em decorrência da interferência imposta pelas plantas daninhas. Para Grove (1988), o nitrogênio e o fósforo são elementos que mais comumente limitam o crescimento de florestas.

Ellis et al. (1985) verificaram em solo de pastagem que a taxa reduzida de suprimento de nitrogênio mineral foi o principal fator a limitar o crescimento de plantas jovens de Eucalyptus delegatensis. Também Ahimana e Maghembe (1987) observaram que a concentração de nutrientes foi significativamente menor em plantas de Eucalyptus tereticornis que conviviam com plantas infestantes do que aquelas livres da presença destas plantas.

Allan et al. (1986) verificaram que, em áreas de Pinus taeda, o preparo do solo adequado, a aplicação de N, P e K e o controle da comunidade infestante, principalmente das plantas herbáceas e lenhosas, nos primeiros quatro anos, aumentaram o volume da espécie plantada de $11,8 \mathrm{~m}^{3} \cdot \mathrm{ha}^{-1}$ para $25,9 \mathrm{~m}^{3} \cdot \mathrm{ha}^{-1}$ aos cinco anos.

Nambiar (1992), estudando a competição entre árvores de Pinus radiata e plantas daninhas por água e nitrogênio, verificou que o aumento da faixa de controle das plantas daninhas proporcionou maior absorção de água e nitrogênio pela espécie florestal, principalmente nos solos onde as reservas deste nutriente eram baixas. A adubação nitrogenada nos tratamentos sem controle das plantas daninhas intensificou a competição anulando, em parte, os efeitos da fertilização.

Smethurst (1993) avaliou as relações de interferência entre Pinus elliottii Engelm. var. elliottii e plantas daninhas por fósforo e potássio durante 187 dias após o plantio e observou que na presença das plantas daninhas a quantidade 
destes nutrientes absorvida pelas árvores foi sensivelmente reduzida, principalmente potássio, com reflexos negativos ao crescimento do $P$. elliottii.

Deve-se considerar que, em muitas situações, os teores dos elementos essenciais são pouco alterados pela interferência da comunidade infestante, porém, a quantidade absorvida pelas árvores é bastante reduzida, o que é um reflexo do menor crescimento e acúmulo de matéria seca (Pitelli \& Marchi, 1991).

Marchi (1989), observou que os teores de macronutrientes presentes nos tecidos vegetais da parte aérea das plantas de Eucalyptus urophylla foram pouco reduzidos pela interferência das plantas daninhas, porém o acúmulo de todos os elementos foi muito menor em plantas em convivência com Brachiaria decumbens ou com Panicum maximum.

\subsection{Interceptação da luz}

Em sistemas florestais onde fatores como água e nitrogênio limitam o crescimento e a produção da cultura, as plantas competem por luz tanto quanto por outros recursos. Por isso, é extremamente difícil de distinguir a contribuição pelos diferentes recursos na redução da produtividade da cultura. A luz é um fator cujo suprimento em uma determinada área é perfeitamente previsível; no entanto, em contraste com água e nutrientes, a luz não pode ser acumulada para posterior uso. Ela tem que ser consumida quando recebida, ou será perdida para sempre. É um processo instantâneo de captura desse recurso (luz) e a eficiência dessa competição está diretamente relacionada a interceptação da luz pelas plantas daninhas (Kropff \& Van Laar, 1993). A compreensão do impacto dos fatores envolvidos nessa competição pode auxiliar o manejo integrado de plantas daninhas, a medida que se desenvolvem clones (híbridos) de eucalipto mais competitivos.

A luz varia em duração, intensidade e qualidade. As plantas reduzem o suprimento da luz das plantas vizinhas através do sombreamento. As folhas que interceptam a luz podem refleti-la, converte-la diretamente em fotossintatos, calor, 
ou transmiti-la. Se transmitida, a luz é filtrada e receptada pelas folhas inferiores, porém com espectro alterado.

Segundo Kropff \& Van Laar (1993), a interceptação da luz pela comunidade infestante é determinada pelo índice de área foliar, altura da planta e as características foliares relacionadas àabsorção de luz. De acordo com De W it ${ }^{5}$, citado por Kropff \& Van Laar (1993), os melhores competidores não apresentam necessariamente maiores áreas foliares, mas sim uma melhor distribuição das folhas em arquitetura mais adequada para interceptar o máximo de luz. Desta forma, a capacidade de competição por luz de uma planta é influenciada pelo ângulo da folha, ou seja, plantas com folhas mais horizontais são mais competitivas que plantas com folhas verticais. Plantas com folhas opostas são provavelmente menos competitivas que plantas com folhas alternas. Berkowitz ${ }^{6}$ citado por Kropff \& Van Laar (1993) descreveu uma forte relação entre a altura da planta e a capacidade de interceptação de luz em muitas espécies cultivadas. Segundo estes autores, as plantas mais altas ou eretas têm uma grande vantagem competitiva por luz quando comparadas as plantas mais baixas ou prostradas. As plantas que se encontram altamente sombreadas sofrem uma redução drástica na fotossíntese, resultando em um baixo crescimento, um sistema radicular menos desenvolvido, e baixa capacidade de absorver água e nutrientes do solo. O efeito do sombreamento é independente da competição direta por água e nutrientes, e inteiramente sob influência da luz (Kropff \& Van Laar, 1993).

Além desses fatores que determinam o processo de captura da luz, a dinâmica envolvida neste sistema durante o período de crescimento das plantas e especialmente o mecanismo de resposta a competição por luz tem sido estudados (Kropff \& Van Laar, 1993).

${ }^{5}$ DE WIT, C.T. Photosynthesis of leaf canopies. 1965. In: KROPFF, M.J.; VAN LAAR, H.H. Moddeling Crop-Weed Interactions. Ed. International Rice Research Institute, Philippines And Wageningen Agricultural University The Netherlands. 1993. 274 p.

${ }^{6}$ BERKOWITZ, A.R. Competition for resources in weed crop mixture. In: KROPFF, M.J.; VAN LAAR, H.H. Moddeling Crop-Weed Interactions. Ed. International Rice Research Institute, Philippines And Wageningen Agricultural University The Netherlands. 1993. 274 p. 
Segundo Kropff \& Van Laar (1993), outras características de competitividade relacionadas a absorção de luz tem sido observadas no uso eficiente da luz, como as características fotossintéticas que determinam a habilidade competitiva de plantas $\mathrm{C}_{3}$ e $\mathrm{C}_{4}$.

A interceptação da luz solar é uma das modalidades de interferência das plantas daninhas que provoca maior impacto sobre o crescimento das espécies florestais, pois restringe a fonte predominante de energia aos processos básicos de recrutamento dos elementos e de elaboração de todas as substâncias envolvidas no crescimento e desenvolvimento do vegetal. Além disso, a filtragem seletiva dos raios luminosos pela folhagem da comunidade infestante, pode fomentar o estiolamento de árvores jovens. Estas normalmente apresentam pequena área foliar localizada no topo dos caules relativamente longos. Com isso, o transporte ascendente de água é dificultado, pois necessitaria de um grande déficit energético entre a copa e o sistema radicular, o que é difícil de ocorrer devido à pequena superfície de transpiração e o sombream ento. A interceptação da luz é muito mais importante nas fases precoces de implantação da floresta (Pitelli \& Marchi, 1991).

\subsubsection{Alelopatia}

Certas espécies de plantas interferem alelopaticamente contra a planta cultivada causando sérios prejuízos ao seu crescimento, desenvolvimento e produtividade (Pitelli, 1987).

O termo alelopatia (do grego allelon = mútuo e pathos = prejuízo) foi utilizado para se referir a toda interação bioquímica entre seres vivos, incluindo microrganismos. Apesar desta definição abranger tanto as relações prejudiciais como as benéficas, Rice (1974) propôs a seguinte definição "qualquer efeito prejudicial, direto ou indireto, de uma planta sobre a outra pela produção de compostos químicos, liberados no meio", denominados de aleloquímicos. Para estes autores, o conjunto de interações denominadas aleloquímicas intervém os compostos químicos, com 
os quais organismos de uma espécie afetam o crescimento, estado sanitário, comportamento ou a biologia da população de organismos de outra espécie, excluindo substâncias usadas apenas como alimentos pela segunda espécie.

Velini (1992) afirma que é extremamente difícil isolar os efeitos dos vários processos pelos quais as plantas afetam umas as outras, principalmente os efeitos da competição e da alelopatia, no que é corroborado por Alves (1992), que complementa citando que a competição entre as plantas reduz ou remove do ambiente um fator de crescimento necessário a ambas, enquanto na alelopatia ocorre a adição de um fator ao meio.

Os aleloquímicos podem ser produzidos em qualquer parte da planta e liberados por exsudatos radiculares e da parte aérea, de sementes, em pleno processo germinativo e, também de resíduos de certas plantas, durante o processo de decomposição (Pitelli, 1987).

Norby \& Kozlowski (1980), procurando determinar o potencial alelopático de seis espécies comuns em florestas de Pinus resinosa, e já descritas por seu potencial alelopático sobre outras espécies, verificaram que a elongação da radícula de sementes recém germinadas foi reduzida em até $48 \%$ quando comparada à do controle, sendo também inibidos o crescimento em altura, a formação de acículas secundárias e o aumento de peso de matéria seca de plantas de Pinus resinosa, durante os sete meses do experimento. Hollis et al.., (1982) observaram forte inibição na germinação e na extensão radicular de Pinus elliottii e Pinus taeda por extrato foliar de Eupatorium capilliofolium e de Lyonia lucida, espécies comuns sob florestas de ambas às espécies de Pinus.

Souza et al. (1993) estudaram em condições de casa de vegetação, a possível ocorrência de efeito alelopático de dezoito espécies de plantas daninhas sobre o crescimento inicial de Eucalyptus grandis, e observaram alterações importantes no desenvolvimento das mudas, tais como, desaceleração no crescimento, em altura, diâmetro do caule, produção de matéria seca e variações no teor de clorofila. Dentre as espécies testadas, a Brachiaria decumbens 
provocou os efeitos mais drásticos, principalmente no desenvolvimento da parte aérea, reduzindo em $97,7 \%$ e $62,8 \%$ acumulada de matéria seca de caules e folhas e raízes das plantas de eucalipto, respectivamente.

\subsubsection{Parasitismo}

Outra forma importante de interferência direta das plantas daninhas é o parasitismo. No Brasil, embora em termos agrícolas, as plantas parasitas não tenham grande expressão, pode-se citar espécies ornamentais e Citrus sp. sendo parasitadas por plantas do gênero Cuscuta (Pitelli, 1987).

Duas plantas daninhas parasitas que têm causado imensos prejuízos em diversos países são a Striga sp (erva-de-bruxa) e o Orobanche sp. A Striga sp parasita o sistema radicular de gramíneas e algumas dicotiledôneas. Já o Orobanche sp parasita a raiz de culturas dicotiledôneas, principalmente olerícolas (Victoria Filho, 2000).

Em ecossistemas florestais, são inúmeras as plantas superiores que parasitam outras plantas produzindo estruturas vegetativas, flores e sementes, de modo similar às plantas hospedeiras. De acordo com Ferreira (1989), a erva -depassarinho (Shuthanthus marginatus) é uma planta parasita que prejudica o crescimento e produtividade de plantas de interesse florestal como ciprestes (Cupressus spp), casuarinas (Casuarina spp.) e ligustros (Ligustrum spp.). O cipó - chumbo (Cuscuta spp) é citado parasitando ligustros e ipê - amarelo (Tabebuia serratifolia), sendo que também podem ser importantes na transmissão de viroses entre indivíduos (Pitelli, 1987).

\subsubsection{Depreciação da qualidade do produto florestal}

A comunidade infestante também pode interferir diretamente depreciando a qualidade do produto florestal. Por exemplo, algumas plantas daninhas 
trepadeiras ou cipós enrolam-se junto ao tronco das espécies florestais, impedindo o seu crescimento e forçando o aparecimento de brotações laterais ocasionando nós, que depreciam a qualidade da madeira (Toledo, 1998).

\subsubsection{Interferências indiretas}

Dentre as interferências indiretas sobre as espécies florestais sobressaem os efeitos físicos ou biológicos que intervém nas plantas próximas como, por exemplo, a ação de herbívoros (Rice, 1974; Halligan, 1976).

\subsubsection{Danos físicos}

Muitas espécies de plantas daninhas trepadeiras, como o cipó-de-SãoJoão (Pyrestegia venusta), podem causar sérios danos físicos às espécies florestais, reduzindo o estande da cultura, pois elevam a mortalidade de mudas e conseqüentemente o custo com replantio ou causando deformações nos troncos. As plantas florestais dominadas por estas plantas daninhas concentram seus esforços para o crescimento em altura e quase sempre, ficam como plantas dominadas, e assim não expressam totalmente seu potencial genético de produção de biomassa (Pitelli \& Marchi, 1991).

Os mesmos autores destacam ainda que as plantas daninhas trepadeiras proporcionam suporte mecânico a espécies florestais fazendo com que as plantas cultivadas fiquem mais altas rapidamente, reduzindo assim o espessamento do caule. As conseqüências fisiológicas resultantes desta interferência são similares ao estiolamento, além de elevar o centro de gravidade da planta tornando-a mais suscetível ao tombamento, quando a comunidade infestante for controlada.

\subsubsection{Hospedeiras intermediárias de pragas e doenças}

Outra forma de interferência indireta é quando as plantas daninhas atuam como hospedeiras alternativas de pragas, patógenos, nematóides e plantas parasitas. Segundo Galli (1980), algumas goiabeiras nativas atuam como 
importantes hospedeiras alternativas da ferrugem (Puccinia psidii) e do besouroamarelo (Costalimaita ferruginea). Nessas áreas florestais, o manejo integrado do besouro-amarelo é dificultado pelo fato das larvas deste inseto viverem no solo e se alimentarem dessas plantas hospedeiras e de gramíneas, dentre elas o capimbraquiária, que são atacadas pela fase adulta do Costalimaita ferruginea (Mendes et al., 1998).

As plantas daninhas dificultam ou inviabilizam os programas de controle de nematóides pela rotação de culturas não susceptíveis. Para ilustrar, apenas para o Meloidogyne javanica, só no Brasil, já foram relatadas mais de 57 espécies de daninhas que atuam como hospedeiras, dentre as quais pode-se destacar: a Brachiaria plantaginea, Eleusine indica, Bidens pilosa, Ageratum conyzoides e outras, espécies de ocorrência ampla e generalizada em ambientes agrícolas (Pitelli, 1987).

\subsubsection{Propagação de incêndios}

Em muitas áreas florestais a ocorrência de catástrofes normalmente se deve ao fogo. Nestas áreas o custo de produção é elevado com as operações de controle mecânico ou químico das plantas daninhas em aceiros, em torno de toda área plantada e, entre talhões, quando a área é bastante extensa (Deuber, 1997; Mc Nabb, 1997).

Em muitos lugares próximos a cidades e rodovias, existe o elevado risco de pessoas fumantes incendiarem as florestas. $O$ fogo pode ocasionar riscos inerentes de danos, em circunstancias nas quais não foi planejado e devidamente manejado. Não somente existe risco humano, mas utilização do fogo para o controle da vegetação espontânea e preparo da área para o plantio quando executado de forma incorreta pode causar sérios danos ambientais. O controle de incêndios é indispensável, pois provocam a destruição da matéria orgânica dos solos, possibilitando redução na produtividade das florestas. A volatilização do nitrogênio é também outro fator importante no decréscimo da produtividade local. 
Tanto a perda da matéria orgânica, como a de nitrogênio deve ser seriamente consideradas na avaliação do potencial risco de incêndios em áreas florestais (Mc Nabb, 1997).

Certas espécies de plantas daninhas, durante os períodos de estiagem ou no fim do ciclo de desenvolvimento, secam intensamente e podem constituir em agentes de propagação de incêndios, atingindo áreas florestais. O capim-favorito (Rhynchelytrum repens) é uma dessas espécies que tem estas características que provoca vários acidentes deste tipo pois infesta intensamente áreas laterais de rodovias (Pitelli \& Karam, 1988). Nas áreas de cerrado, o capim-gordura (Melinis minutiflora), o capim-colonião (Panicum maximum) e o capim-braquiária (Brachiaria decumbens) também atuam como agentes de propagação de incêndios, nos meses finais de estiagem de inverno (Toledo, 1998).

\subsubsection{Lesões provocadas pelos métodos de controle das plantas daninhas}

As técnicas empregadas no controle da comunidade infestante podem lesionar as espécies florestais, constituindo outro fator de interferência indireta das plantas daninhas.

Aplicações de oxyfluorfen em áreas de Eucalyptus citriodora podem causar cloroses e necroses em folhas de plantas novas de eucalipto, como é citado por Silva et al. (1994), em experimentos de tolerância de espécies deste gênero a herbicidas. Já aplicações de glyphosate de maneira incorreta ou no caso de deriva do produto podem ocasionar o amarelecimento nas folhas de eucalipto que facilmente queimam, reduzindo assim a área foliar e dependendo da fitotoxicidade provocam a morte das mudas de eucalipto. O imazapyr é outro herbicida que apesar de não causar o amarelecimento das folhas de eucalipto, pode ocasionar sintomas de fitotoxicidade na cultura do eucalipto devido ao efeito residual prolongado no solo (Mc Nabb, 1997). 
O controle mecânico das plantas daninhas nas áreas florestais realizados com grade e roçadeira pode causar danos no sistema radicular das espécies florestais. As operações de capina ou ceifa, manuais ou mecânicas freqüentemente destroem mudas jovens ou provocam feridas em indivíduos maiores, facilitando a instalação e a penetração de agentes fiopatogênicos (Pitelli \& Karam, 1988).

\subsubsection{Proteção de alguns inimigos naturais das espécies florestais}

A infestação de plantas daninhas promove abrigo para proteção e procriação de alguns inimigos naturais de espécies florestais, sem atuar necessariamente como hospedeiras intermediárias.

Um caso típico, é o de ratazanas que roem o córtex basal dos caules e a parte inferior das raízes provocando, quase sempre, a morte das plantas. Em solos livres de plantas daninhas, as ratazanas são presas fáceis dos predadores e, além disso, possuem poucos nichos ecológicos para nidificação. Nestas condições, as populações destes roedores não atingem níveis suficientes para provocar danos significativos no reflorestamento. De acordo com Pitelli \& Marchi (1991) fica evidente que quanto maior é a área de controle de plantas daninhas, menor será a incidência de lesões por ratazanas e maior a sobrevivência das espécies florestais.

Quando as plantas daninhas formam grande massa vegetal cobrindo parcialmente as espécies florestais, criam ambientes propícios à instalação e atividade de lesmas e caracóis, que danificam brotos e folhas novas. Estas condições propícias são, especialmente, proteção contra a insolação e maior permanência de água da chuva e do orvalho, na superfície dos vegetais (Pitelli \& Marchi, 1991).

\subsubsection{Interferências operacionais}


Segundo Toledo (1998) alguns tipos de interferência não atuam diretamente sobre as plantas florestais, mas sobre o funcionamento da propriedade rural envolvendo despesas, e alterando a eficiência do homem e de várias operações culturais, como aplicações de defensivos, colheita e retirada da madeira.

Neste último aspecto, Pitelli (1987) cita que plantas daninhas de porte aéreo, como a Mimosa scabrelha (bracatinga) e rebrotas de cerrado tem causado sérios prejuízos.

Já como interferências na operacionalização do processo produtivo, podese citar o fato do manejo agrícola tornar-se mais difícil e oneroso em áreas com a presença de plantas daninhas, pois há a necessidade de cultivos adicionais durante o ciclo da cultura, principalmente quando o período entre o preparo do solo e o plantio das mudas é relativamente longo. Essas operações envolvem custos e deslocamento de mão-de-obra e de equipamentos. Além disso, as operações culturais, de corte e retirada da madeira, ficam mais complicadas pela dificuldade de tráfico nos espaços entre linhas de plantio.

Segundo Toledo (1998), a presença das plantas daninhas em convivência com as espécies florestais pode prejudicar certas práticas culturais. No Sul da Bahia, os trabalhadores rurais negam-se a capinar áreas infestadas florestais infestadas com Cnidoscolus urens (cansanção), pois com leve contato com a planta, ocorre o rompimento dos tricomas de suas folhas e caules, liberando substâncias fortemente urticantes, entre os quais a histamina. Quando penetram na pele, os ferimentos são muito doloridos, levando dias até que a dor desapareça completamente. Em pessoas sensíveis, ou quando os ferimentos são intensos, podem ocorrer dermatites severas (Kissmann, 1992). Já na região de São Carlos, SP, é possível observar talhões de eucaliptos infestados com gravatá (Ananas sp). Nestas áreas florestais, várias operações silviculturais não podem ser executadas devido ao fato desta planta daninha ser perene, medindo 80 a $120 \mathrm{~cm}$ de altura e 
conter espinhos (25 a 50) voltados para cima, apresentando grande vigor vegetativo, formando assim verdadeiras barreiras impenetráveis.

Nos reservatórios de água para irrigação de viveiros e captação de água para pulverização, as plantas aquáticas como a taboa (Typha spp.), aguapé (Eichhornia crassipes), a capituva (Echinochloa plystachia) podem reduzir suas capacidades de armazenamento, aumentar as perdas de água por evapotranspiração, além de constituir sítios de retenção de materiais erodidos de áreas à montante. Com isso, aumentam a rapidez de assoreamento e exigem constantes operações de drenagem (Pitelli \& Marchi, 1991).

As plantas daninhas podem ainda, prejudicar a própria vida do trabalhador rural, seja diretamente por intoxicação alimentar ou alergias, seja indiretamente, criando condições propícias à instalação e procriação de insetos vetores de doenças, animais peçonhentos (cobras, aranhas e escorpiões) e outros inimigos do homem (Pitelli \& Marchi, 1991).

\subsection{Fatores que afetam o grau de interferência entre plantas daninhas e as espécies florestais}

Os fatores que afetam o grau de interferência entre plantas daninhas e as espécies florestais podem ser observados no modelo esquemático proposto por Bleasdale $^{7}$ e adaptado por Pitelli (1985). Segundo este esquema, o grau de interferência depende das manifestações de fatores Igados à própria cultura (espécie, variedade ou clone, espaçamento e densidade de plantio), àcomunidade infestante (composição específica, densidade e distribuição), à época e extensão do período de convivência. Além disso, pode ser alterado pelas condições climáticas, edáficas e dos tratos culturais (Pitelli \& Karam, 1988).

A complexidade dessa interação fica evidente pois todos os componentes e condições variam, em graus diversos, com o tempo e de região para região.

\footnotetext{
${ }^{7}$ BLEASDALE, J.K. Studies on plant competition. In: PITTELLI, R.A. (Ed.) Informe Agropecuário, v. 11, n.129, p. 16-27, 1985.
} 
Alguns fatores são pouco alterados, ao passo que outros variam significativamente (Pitelli, 1985).

A intensidade da interferência das plantas daninhas é avaliada pelo resultado da estimativa da produção obtida pela espécie florestal. A redução da produção só pode ser devidamente quantificada em áreas experimentais que contenham parcelas, funcionando como testemunhas isentas das plantas daninhas mas, supridas de todas as demais condições das áreas em estudo (Toledo, 1999).

\subsubsection{Fatores ligados àcultura}

As diferentes espécies de plantas cultivadas variam bastante em suas capacidades de competir e desenvolver sob interferência da comunidade infestante. Salvo os processos de natureza alelopática, os grandes trunfos das plantas cultivadas são: a capacidade de rápido crescimento e recrutamento de recursos do meio e alto poder de interceptação solar, dificultando o acesso e a utilização pela comunidade infestante (Pitelli \& Karam, 1988).

Esses autores relatam o fato de que dentro do próprio gênero Eucalyptus, as espécies variam em velocidade de crescimento e arquitetura, com reflexos no crescimento da comunidade infestante. Esse relato vem de observações pessoais efetuadas no sul no Brasil onde, em áreas adjacentes, a interferência das plantas daninhas é maior em povoamentos de $E$. viminalli quando comparada com $E$. dunii. Este último, além do crescimento mais rápido, desenvolve maior área foliar, com maior poder de interceptação da luz solar.

Brandi et al. (1974) observaram que em condições de controle de plantas

daninhas, E. alba apresentou maior altura que E. botryoides. No entanto, quando não foi efetuado o controle, as plantas de $E$. alba foram menores.

O espaçamento entre linhas de plantio é outro fator fundamental na determinação da capacidade competitiva da cultura, pois, em última análise, determina a precocidade e a intensidade do sombreamento por ela promovido. Geralmente, a medida que se diminui o espaçamento, o sombreamento do solo 
ocorre de maneira mais rápida e intensa, aumentando a eficiência das medidas empregadas no controle de plantas daninhas (Pitelli, 1987).

A cultura do Pinus sp. que apresenta crescimento inicial lento necessita de cuidados especiais no controle das plantas daninhas por período muito maior que a cultura do Eucalyptus sp., que mais rapidamente sombreia o solo dificultando o crescimento das plantas daninhas (Pitelli, 1987).

Outro fator importante a ser considerado é a densidade de plantio. Dentro de certos limites, aumentando-se a população da espécie cultivada numa determinada área, incrementa-se o potencial competitivo da cultura. É claro que, em taxas populacionais elevadas, haverá grande intensidade de competição intraespecífica na cultura, e sua produtividade será menor, em função da grande pressão competitiva que possa ter exercido sobre as plantas daninhas (Pitelli, 1987).

$\mathrm{Na}$ realidade, alterações no espaçamento e na densidade de plantio definem o melhor arranjo das plantas no campo, de modo que haja maior aproveitamento dos recursos ambientais e, ao mesmo tempo, redução na disponibilidade de nichos ecológicos adequados ao desenvolvimento da comunidade infestante (Pitelli \& Karam, 1988). Estudos envolvendo estimativas de ganhos de produção de madeira em povoamentos florestais nos Estados Unidos da América do Norte, em função da modalidade de controle de plantas daninhas, foram realizadas por Carter \& Holt (1978); observaram que apenas com a adequação do estande das plantas cultivadas, houve ganhos estimados foram de $17 \%$ nas regiões norte e sul, $15 \%$ na região costeira margeando o Pacífico e $30 \%$ na região das Montanhas Rochosas, apresentando um ganho médio estimado ao redor de $18 \%$.

\subsubsection{Fatores ligados à comunidade infestante}


Os fatores ligados à comunidade infestante que afetam o grau de interferência, de acordo com Pitelli \& Karam (1988), são: composição específica, densidade e distribuição.

A composição específica da comunidade infestante é fator de fundamental importância na determinação do grau de interferência, pois as espécies integrantes desta comunidade variam bastante em relação aos seus hábitos de crescimento e exigências em recursos do meio.

Pitelli \& Karam (1988) comentam que espécies anuais de grande agressividade como o Panicum maximum (capim-colonião) e Brachiaria decumbens (capim-braquiária) são bastante prejudiciais nas fases iniciais do crescimento das espécies florestais; e as espécies de porte arbustivo e arbóreo são mais competitivas em fases adiantadas no ciclo das florestas.

Segundo Pitelli (1987), geralmente quanto mais próximas morfológica e fisiológicamente são duas espécies, mais similares serão suas exigências em relação aos fatores de crescimento e mais intensa será a competição pelos fatores limitados, no ambiente comum. Este fato consiste num dos principais perigos da monocultura: o herbicida utilizado numa determinada cultura é inócuo a espécies de plantas daninhas fisiológica e/ou morfologicamente semelhantes a ela e que, teoricamente, são mais competitivas. Assim, após anos sucessivos de cultivo de apenas uma espécie vegetal, numa determinada área, é possível a seleção e o desenvolvimento de uma flora altamente competitiva e tolerante à maioria dos produtos herbicidas utilizados na cultura. A rotação de herbicidas ou de manejos adotados pode solucionar este problema.

Zen (1987), em estudos da interferência imposta por duas comunidades de plantas daninhas sobre a cultura de E. grandis, observou efeitos mais pronunciados de Imperata brasiliensis (capim-sapé) sobre o diâmetro do caule e o volume cúbico de madeira, enquanto em áreas florestais dominadas por Pteridium aquilinum (samambaia), os efeitos sobre a mortalidade e altura das plantas foram maiores. 
De acordo com Pitelli \& Karam (1988), quanto maior for a densidade da comunidade infestante maior será a quantidade de indivíduos que disputam os mesmos recursos do meio e, portanto, mais intensa será a competição sofrida pela cultura. Blanco (1972) ressalta que, em comunidades muito densas, a importância de cada espécie como elemento competitivo fica diminuída, ocorrendo maior equivalência entre as diferentes espécies.

Cromer (1973) demonstrou relação negativa entre a densidade das plantas daninhas e o volume de madeira produzido por Pinus radiata. Já Fitzgerald \& Selden (1975) observaram relação positiva entre as porcentagens de controle de plantas daninhas e a produção de madeira produzida por Platanus occidentalis.

É interessante esclarecer que as comunidades infestantes são geralmente diversificadas, o que lhes garante maior estabilidade na ocupação do meio e nos efeitos competitivos sobre as culturas. Estas comunidades, além de diversificadas, normalmente são bastante densas. Deste modo, cada indivíduo não poderia crescer de acordo com seu potencial genético, mas em consonância com as quantidades de recursos que conseguir recrutar, na intensa competição a que está submetido. Desta maneira, em altas densidades, o valor de cada indivíduo como elemento competitivo fica diminuído e o potencial de crescimento da comunidade é controlado por aquele recurso que de acordo com as necessidades gerais da comunidade, apresenta-se em menor quantidade no ambiente. Este fato faz com que haja grande estabilidade do recrutamento de recursos, com as diferentes alterações ambientais, que normalmente é alterado pelos tratos culturais (Pitelli, 1987).

A distribuição das plantas daninhas na área cultivada é outro importante fator que influencia o grau de interferência entre a comunidade infestante e as espécies florestais, principalmente em relação à proximidade entre determinados indivíduos da comunidade e as linhas de plantio do eucalitpo (faixas de controle). Normalmente, plantas bem espaçadas podem desenvolver mais intensamente seus potenciais competitivos individuais (Pitelli, 1987). 
Em estudos realizados por Carter et al. (1984), pode-se observar que a eliminação de todas as plantas infestantes num raio de 1,5 $\mathrm{m}$ ao redor das plantas de Pinus taeda reduziu significativamente a competição por água quando comparados ao tratamento sem a eliminação de plantas daninhas.

Toledo (1998) em pesquisa conduzida em área florestal de Eucalyptus grandis W. Hill ex Maiden x E. urophylla S. T. Blake, no município de Três Lagoas, MS, no período de julho de 1996 a agosto de 1997, com o objetivo de avaliar os efeitos das faixas de controle do capim-braquiária (Brachiaria decumbens) sobre o crescimento inicial deste clone de eucalipto, constatou que a faixa de controle de $150 \mathrm{~cm}$ de cada lado da linha de plantio (testemunha "no limpo") foi a faixa que obteve melhor eficácia no controle desta planta daninha. No entanto, segundo este autor, a largura mínima da faixa de controle a ser utilizada pela empresa florestal em Três Lagoas, MS, a qual proporcionou maior velocidade de crescimento, maior altura e diâmetro do caule das plantas de eucalipto, foi a de $100 \mathrm{~cm}$ de cada lado da linha de plantio, correspondendo a faixa total de 2 metros de largura que não apresentou diferença significativa em relação a outros tratamentos que utilizaram faixas de controle fixas de $100 \mathrm{~cm}$ ou crescentes a partir de $50 \mathrm{~cm}$ de cada lado.

Já para Silva (1999), nas regiões de Araraquara, SP e de Altinópolis, SP, onde a população de planta daninha mais freqüente foi o Panicum maximum (capim-colonião) e o Rhynchelytrum repens (capim-favorito), respectivamente, a largura da faixa de controle necessária para promover maior incremento médio tanto em altura como em diâmetro do caule foi de 50 e $75 \mathrm{~cm}$ de cada lado da linha de plantio, respectivamente, minimizando, com isso, o efeito da interferência dessas plantas daninhas.

\subsubsection{Fatores ligados ao ambiente}

Pitelli \& Karam (1988) citam que os fatores ligados ao ambiente que afetam o grau de interferência podem ser explicados pelo fato de que a comunidade infestante é composta por indivíduos distintos e por muitas espécies 
diferentes, sendo que a resposta de cada um a alterações climáticas e edáficas das diferentes regiões determinam uma mudança no equilíbrio da comunidade e, também na própria cultura, influenciando o balanço competitivo.

O mesmo é válido em relação às práticas culturais empregadas. Por exemplo, a fertilização do solo influencia não só o crescimento das plantas daninhas, sendo que algumas espécies apresentam alterações de crescimento mais intensas que as culturas, quando sujeitas a um tratamento de adubação. Crescendo mais, recrutam mais recursos, inclusive aqueles não adicionados pela fertilização, e com isso exercem maior pressão competitiva na cultura (Pitelli, 1987).

Vários autores como Cromer (1973) e Loiaza (1967) observaram que a adubação de plantas florestais promove um crescimento maior e reduz a sua susceptibilidade à interferência imposta pelas plantas daninhas. O reflexo desse comportamento é o desenvolvimento de uma cultura mais vigorosa com maior poder de interferência sobre comunidades infestantes futuras (Pitelli, 1987).

Apenas a adubação não é prática suficiente para garantir o crescimento da cultura na presença das plantas daninhas, pois a competição, por nutrientes pode ser muito intensa anulando em parte, os efeitos da adubação. No entanto, a localização do adubo, na cova de plantio pode incrementar o potencial competitivo da cultura em maior grau que o da comunidade infestante (Pitelli, 1987).

\subsubsection{Períodos de convivência e de controle das plantas daninhas em áreas florestais}

De todos os fatores que alteram o grau de interferência, o mais importante é, talvez, o período em que a comunidade infestante e as espécies florestais estiverem disputando os recursos do meio (Pitelli \& Karam, 1988). 
É mais estudado o período a partir do plantio das mudas em que as plantas de eucalipto devem ser mantidas livres da presença das plantas daninhas para que a produção não seja afetada quantitativa e/ou qualitativamente. $\mathrm{Na}$ prática, esse deve ser o período em que as capinas ou o efeito residual do herbicida devem cobrir. É interessante esclarecer o significado deste período em termos de interferência: as espécies de plantas daninhas que emergirem neste período, em determinada época do ciclo da cultura, terão atingido tal estádio de desenvolvimento que promoverão uma interferência, sobre as plantas de eucalipto, capaz de reduzir significativamente sua produtividade econômica. Por isso, é chamado por Pitelli \& Durigan (1984) de período total de prevenção àinterferência (PTPI), após o qual, a própria cultura, por meio do sombreamento, principalmente, controla e impede o crescimento das plantas daninhas. Assim, toda e qualquer prática cultural que incrementa o crescimento inicial da cultura pode contribuir para um decréscimo no período total de prevenção da interferência, permitindo menos cultivos ou uso de herbicidas de melhor efeito residual (Pitelli, 1987).

Outro tipo de período estudado é a época, a partir do plantio, em que a espécie florestal pode conviver com a comunidade infestante, antes que a interferência se instale de maneira definitiva e reduza significativamente a produtividade da cultura, sendo designado por Pitelli \& Durigan (1984) de período anterior à interferência (PAl). Seu limite superior retrata a época em que a interferência compromete irreversivelmente a produtividade econômica da cultura. A aplicação de certas práticas culturais contribui para a diminuição deste período. Por exemplo, a fertilização incrementa o crescimento da cultura e das plantas daninhas, permitindo que a competição por aqueles recursos não condicionados pela adubação se instale de maneira mais rápida (Pitelli, 1987).

Teoricamente, o final do período anterior àinterferência seria a época ideal para o primeiro controle das plantas daninhas, pois essas plantas teriam acumulado uma quantidade de energia e matéria que retornaria ao solo contribuindo para o próprio desenvolvimento da espécie florestal. Mas, na prática, 
geralmente este período não pode ser considerado, pois a espécie florestal e/ou as plantas daninhas podem ter atingido tal estádio de desenvolvimento que inviabilize o uso de práticas mecânicas ou o controle químico.

Finalmente, o terceiro período estudado é o denominado de período crítico de prevenção da interferência (PCPI) que, basicamente, é o controle das plantas daninhas imediatamente antes que os recursos sejam disputados, prolongando-se o controle até um período após o qual as plantas daninhas que emergirem não mais concorram com a cultura (Pitelli, 1987).

De modo geral, poderia se dizer que, quanto maior for o período de convivência entre o eucalipto e a comunidade infestante, maior seria o grau de interferência. No entanto, segundo Pitelli (1987), isto não é totalmente válido, porque dependerá da época do ciclo da cultura em que este período for considerado. Os períodos encontrados por diferentes autores não são idênticos, o que pode ser explicado pelo fato das condições de condução das pesquisas, as próprias espécies ou clones utilizados e as composições específicas das comunidades infestantes serem diferentes e que dada a diversidade desses fatores que influenciam no grau e nos períodos de interferência, torna-se extremamente importante que estas pesquisas se intensifiquem e ultrapassem os limites dos centros de pesquisas e universidades, sendo executadas pelas empresas florestais que pretendam informações mais significativas para as suas áreas de produção (Toledo, 1998).

$\mathrm{Na}$ cultura de Eucalyptus sp. são poucos os estudos sobre os períodos considerados críticos nas suas relações de interferência com a comunidade infestante. Andrade (1961) cita que o eucalipto é uma planta sensível a esta interferência e sugere que o controle das plantas daninhas seja realizado nos dois primeiros anos. Osse (1961) sugere que o período de controle deve ser maior quando as florestas são infestadas por gramíneas

Lamb (1975) afirma que o adequado controle de plantas daninhas durante o primeiro ano após o plantio é essencial para o sucesso do estabelecimento de 
plantações de Eucalyptus em Papua (Nova Guiné). Chingaire (1985) relata que o crescimento das plantas Eucalyptus camaldulensis que conviveram com as plantas daninhas por 15 meses de idade foi significativamente menor do que as plantas de eucalipto que cresceram livres da presença das plantas daninhas.

Zen (1987) observou que, em áreas infestadas por samambaias (Pteridium aquilinum), o controle de plantas daninhas por 60 dias assegurou 0 crescimento e o diâmetro do caule de Eucalyptus grandis.

Protil (1992), estudando o crescimento e a composição mineral de Eucalyptus urophylla submetido à interferência de plantas daninhas, constatou relação negativa entre a concentração de $\mathrm{N}$ e $\mathrm{K}$ nas folhas e os períodos crescentes de convivência com a comunidade infestante. A mesma correlação foi constatada para a concentração de N, P, K, Ca e Mg nos ramos e hastes das plantas florestais, sendo que a maior competição por nutrientes se deu quando o período de convivência foi de 84 dias. A autora relata, ainda, que a cultura do eucalipto foi beneficiada quando mantida livre da interferência das plantas daninhas até 98 dias após o plantio.

Resultados experimentais evidenciam uma grande interferência promovida pela comunidade infestante na cultura de Eucalyptus grandis, especialmente quando há grande incidência de plantas do gênero Brachiaria (Bezutte et al., 1993). Os mesmos autores, em estudo de efeitos de períodos crescentes de convivência das plantas daninhas sobre o crescimento e a produtividade de Eucalyptus grandis, realizado em solo arenoso no qual predominavam $B$. decumbens e B. brizantha, observaram que a cultura pode conviver por 56 dias com a comunidade infestante sem redução significativa. Por outro lado, foi observado um período de controle necessário de 168 dias para que não houvesse redução significativa da altura.

Kogan et al. (1995), em experimentos realizados com Eucalyptus nitens observaram que, tanto para os plantios de outono como para os de primavera, as plantas daninhas iniciaram a interferência muito precocemente. Bastaram somente 
30 dias de convivência para que proporcionassem reduções de 20 - 50 \% na área de secção. O período total de prevenção (PTPI) na plantação de outono foi aproximadamente de 240-250 dias. Isto indicaria que logo após o plantio seria necessário manter a cultura livre das plantas daninhas por um período de pelo menos 8 meses, para se obter um máximo de área de secção. No entanto, o PTPI na plantação de primavera foi menor, indicando que logo após o plantio das mudas seria necessário um período de controle das plantas daninhas de 120 dias para assegurar uma adequada área de secção.

Os resultados observados na literatura mostram que, em determinadas espécies florestais, os períodos encontrados pelos diferentes autores não são idênticos, o que pode ser considerado normal, pois as condições nas quais foram conduzidas as pesquisas são distintas, ou seja, os fatores que afetam o grau de interferência das plantas daninhas em áreas florestais são diferentes (espécies florestais ou clones; espaçamento, composição específica, densidade e distribuição das plantas daninhas; ambiente e práticas silviculturias).

\subsection{Manejo de plantas daninhas em áreas florestais}

O manejo integrado de pragas (MIP) tem sido definido como um sistema de manejo que utiliza todas as técnicas e métodos adequados de forma compatível, mantendo as populações de pragas nocivas a níveis abaixo daqueles que causam danos econômicos (Labrada et al., 1994). Assim, os entomologistas introduziram valiosos conhecimentos relativos àdinâmica populacional de insetos e inimigos naturais, valores de danos econômicos, e outras informações para estabelecer métodos que possam predizer o aparecimento de pragas importantes.

A missão da pesquisa na agricultura é desenvolver tecnologias que diminuam as perdas e os custos do controle de pragas, doenças e plantas daninhas, propiciando a produção de alimentos saudáveis, de alta qualidade e 
com menor impacto no ambiente. Bertrand ${ }^{8}$ citado por Victoria Filho (2000) apresenta o conceito de manejo integrado de pragas, doenças e plantas daninhas (IPMS) pelo Departamento de Agricultura dos Estados Unidos da América do Norte (USDA) como sendo um sistema que seleciona, integra e usa de métodos de controle, tendo como base a antecipação de suas conseqüências nas áreas econômica, ecológica e social.

Segundo o mesmo autor, o manejo integrado de plantas daninhas (Integrated Weed Management Systems - IWMS) faz parte do manejo integrado de pragas, doenças e plantas daninhas (IPMS). Assim, os objetivos do manejo integrado de plantas daninhas são: reduzir as perdas causadas pelas plantas daninhas, os custos de controle, a energia e outras operações; reduzir o cultivo, a erosão do solo causada pela água e vento; assegurar uma produção adequada de produtos agrícolas e florestais; evitar danos por plantas tóxicas; e manter a qualidade ambiental com a maximização de lucro para o produtor.

O termo manejo de plantas daninhas é a combinação de uma forma racional de medidas preventivas, como também de medidas de controle e erradicação se necessárias em um determinado agroecossistema. O termo controle é utilizado para o emprego de medidas específicas para minimizar a interferência das plantas daninhas, ou seja, para que a presença das plantas daninhas não cause dano econômico.

Os cientistas das plantas daninhas devem estar envolvidos com a prática da agricultura e utilizar medidas de manejo em vez de controle da comunidade infestante, mudando a ênfase para a adoção de medidas de manejo de plantas daninhas em uma agricultura economicamente sustentável. Para a adoção destas medidas de manejo, a ciência das plantas daninhas deverá elucidar dados importantes com relação à dinâmica populacional das plantas daninhas, níveis de

8 BERTRAND, A.R. Sea Integrated Pest Management Programs. In: VICTORIA FILHO, R. Estratégias de manejo integrado de plantas daninhas. 348-363 p. Manejo Integrado: Doenças, Pragas e Plantas Daninhas. Ed. Zambolim, L. Viçosa: UFV Depto de Fitopatologia. 2000, 416 p. 
danos econômicos das espécies predominantes e outros métodos não convencionais de controle das plantas daninhas (Victoria Filho, 2000).

Para estudar as diferentes estratégias empregadas no manejo de plantas daninhas em agroecossistemas, é interessante observar o ciclo de vida das comunidades infestantes nestes ambientes. Este ciclo foi esquematizado por Bantilan ${ }^{9}$, citado por Pitelli (1987). Neste esquema pode-se observar duas fases: 0 balanço de interferência cultura - comunidade infestante e a capacidade das plantas daninhas em manter e expandir suas populações (Pitelli, 1987).

Segundo Pitelli \& Karam (1988), uma cultura, ao ser implantada em determinado agroecossistema, encontra, no solo, uma certa quantidade de propágulos que vão emergir espontaneamente durante o seu ciclo de vida. Neste período, estabelece-se uma relação de interferência envolvendo a cultura e a comunidade infestante sendo do balanço final desta relação que se tem a produtividade da cultura e a quantidade de propágulos produzidos pelas plantas daninhas.

Os mesmos autores citam ainda, que o potencial de propágulos de uma estação de crescimento, irá se juntar ao potencial de infestação da próxima estação. Por isso, o manejo de comunidades infestantes pode ser considerado um programa a longo prazo em que, inclusive as práticas aplicadas ao manejo de uma cultura numa determinada estação visam reduzir potenciais futuros de infestação.

Deste modo, o conhecimento das relações de interferência entre plantas daninhas e as culturas florestais pode fornecer subsídios valiosos as empresas florestais, que podem imprimir um manejo æ̀s suas áreas florestais, com reflexos favoráveis às medidas d e controle empregadas (Pitelli \& Karam, 1988).

Nos plantios com espécies florestais a ausência ou deficiência no controle das plantas daninhas pode se tornar fator limitante ao bom desenvolvimento das plantas, devido a fatores anteriormente citados.

\footnotetext{
${ }^{9}$ BANTILAN, P. Integrated weed management: 1. Key factors affecting crop weed balance. In: PITELLI, R.A. Série Técnica - IPEF, Piracicaba, v.4, n12, p 1-24, 1987.
} 
De um modo geral, os sistemas de controle de plantas daninhas em áreas florestais dependem de vários fatores, tais como: histórico da área, espécie cultivada, idade do plantio, características morfofisiológicas e taxa de colonização da vegetação invasora, topografia do terreno e outros (Brito, 1995).

A combinação desses fatores deve determinar o sistema mais adequado de controle que pode variar desde a utilização de sistemas manuais como capina/roçada manual em área total ou coroamento, capina/roçada mecanizada, controle com herbicidas, uso de fogo sob forma controlada, combinações de sistemas e outros (Brito, 1995).

\subsubsection{Controle Preventivo}

As medidas preventivas consistem na adoção de medidas que impeçam ou minimizem a introdução e a disseminação de plantas daninhas em um determinado local. Já a erradicação consiste na eliminação total de sementes e propágulos de uma espécie infestante em uma determinada área. Algumas medidas preventivas são: a) limpeza de equipamentos de preparo do solo e outros implementos agrícolas; b) utilização de mudas livres de plantas daninhas; e c) manter livre de plantas daninhas canais de irrigação e outras áreas próximas à propriedade, como também as áreas na entressafra, utilizando-se de um sistema adequado de rotação de culturas (Victoria Filho, 2000).

Além das medidas preventivas de plantas daninhas, os principais métodos de controle podem ser resumidos em cultural, biológico, físico, mecânico e químico. Todos esses métodos englobam práticas eficientes quando empregadas de modo correto. Devem estar perfeitamente inseridos nos objetivos econômicos e adaptados às condições locais de infra-estrutura, uma vez não ser possível generalizar uma única fórmula padrão, rigidamente aplicável às diferentes situações e de modo a obter eficiência máxima. As opções a serem adotadas deverão ser em função das características locais, incluindo, entre outras, a composição específica da população de plantas daninhas, o grau de infestação, a 
disponibilidade de mão-de-obra e de implementos, o nível sócio-cultural do produtor e, basicamente, os custos operacionais comparativos (Victoria Filho, 2000).

\subsubsection{Controle Cultural}

As plantas daninhas e as espécies florestais ao crescerem em um mesmo ambiente seus sistemas radiculares ocuparão espaços iguais, requerendo, assim, um suprimento adequado de nutrientes e água. Pode-se utilizar medidas que modifiquem essa relação planta daninha - cultura, favorecendo a espécie florestal no aspecto competitivo. Essas medidas culturais podem ser as seguintes: a) escolha de espécies florestais ou clones adaptados às condições locais, propiciando um rápido crescimento e ocupação do espaço físico; b) espaçamento e época de plantio, ou seja condições favoráveis ao estabelecimento da cultura permitindo a ocupação da superfície do solo o mais rápido possível; c) uso de culturas intercalares e adubação verde (sistemas de produção que se adotados de uma maneira razoável diminuem a infestação de plantas daninhas na área e d) coberturas vivas e mortas com potenciais alelopáticos (Victoria Filho, 2000).

Segundo Pitelli (1987), a utilização da cobertura morta pode ser inserida no manejo integrado de plantas daninhas de forma bastante eficiente, principalmente na prevenção de crescimento inicial de plântulas de espécies anuais, prejudicando a fotossíntese nesta fase jovem, levando na maioria das vezes a morte dessas plantas.

\subsubsection{Controle Biológico}

O controle biológico de plantas daninhas pode ser definido como a ação de parasitas, predadores ou patógenos na manutenção de uma população em uma densidade menor que aquela que ocorre naturalmente, e que não cause dano econômico. De um modo geral, o equilíbrio entre a população do agente biológico 
e a população da planta daninha ocorre em nível abaixo do dano econômico e não há erradicação da planta daninha (Victoria Filho, 2000).

O controle biológico clássico seria a introdução de um agente biológico no controle de plantas daninhas exóticas, e que estão amplamente disseminadas no ambiente. Normalmente, esse agente é introduzido no local de origem da planta daninha. Já o controle biológico inundativo utiliza fungos e bactérias de uma forma maciça sobre uma população de planta daninha para criar um rápido elevado nível de doença (Charudattan \& Pitelli, 1993).

As pesquisas envolvendo o controle biológico de plantas daninhas em áreas florestais estão sendo incentivadas em diversos países desenvolvidos como os Estados Unidos da América do Norte, Canadá e Suiça, devido a não aceitação ecológica do uso de herbicidas, apesar do controle químico de plantas daninhas ser mais eficiente e de menor custo até o presente momento (Prassad, 1997).

De acordo com Prassad (1997), o controle de Prunus serotina em plantações de coníferas é realizado na Holanda através de um fungo (Chondosterum purpureum). No Canadá este fungo está na fase de registro para o controle biológico de rebrotas de Alnus rubra.

No entanto, o controle biológico de plantas daninhas, de modo geral, necessita ainda de muitos estudos para ser passível de efetiva, consciente e ampla utilização prática em áreas florestais. Isto se deve a considerável variabilidade de microrganismos e hospedeiros; a falta de conhecimento do modo de ação destes microrganismos e a interação, tecnologia de aplicação, a mistura de tanque e compatibilidade de herbicidas e estes microrganismos.

\subsubsection{Controle Mecânico e Físico}

O cultivo compreende as diversas operações de revolvimento do solo, desde o plantio até a colheita, visando manter o solo, a cultura implantada e o nível de infestação de plantas daninhas sob condições tais, que não restrinjam o 
desenvolvimento normal das espécies florestais, e conseqüentemente não interfiram na produtividade.

O sucesso do cultivo mecânico depende de uma série de fatores como: semelhança da planta daninha com a cultura, germinação das plantas daninhas, presença das plantas daninhas perenes, espaçamento da cultura. O sucesso depende também do conhecimento do banco de sementes no perfil do solo (Victoria Filho, 2000).

As operações de catação manual (monda), a capina manual através da enxada ou mecanizada, roçagem manual e mecânica são bastante utilizadas em diversas empresas florestais. A catação e capina manual são métodos onerosos e apresentam certa dificuldade de uso em áreas extensas de cultivo, embora sejam freqüentemente utilizadas em viveiros, áreas pequenas e, também, com o objetivo de efetuar repasses (Toledo, 1998).

O uso de roçadeiras nas entre linhas de culturas perenes, principalmente em áreas de acentuado declive, torna-se uma prática bastante vantajosa e bastante utilizada.

Dentre os métodos mecânicos, pode-se destacar a utilização da grade. 0 principal objetivo do revolvimento do solo é fornecer condições adequadas ao plantio e posterior estabelecimento das mudas no campo. $O$ favorecimento das mudas, segundo Simões (1989), basicamente, é conseqüência da redução da competição pelas plantas daninhas, além de uma melhoria das propriedades físicas do solo, o que permitirá uma expansão mais fácil do sistema radicular de mudas.

Em solos arenosos e permeáveis, como nas regiões de cerrado, a gradagem pesada e a leve (superficial), tem-se constituído, praticamente, na única operação de revolvimento do terreno. A gradagem superficial atinge aproximadamente $15 \mathrm{~cm}$ profundidade. Quando a gradagem é realizada em duas operações, os sentidos dos cortes são transversais, denominando-a de gradagem cruzada (Simões, 1989). 
Entretanto, apesar de ser o método mais prático, o mesmo apresenta certos inconvenientes, como, um curto período de controle, obrigando a repetir a operação diversas vezes; eliminação apenas da parte aérea; dificuldade de uso da mão-de-obra devido à maior demanda simultaneamente com as atividades de plantio e ou agrícola, além da mão-de-obra estar se tornando escassa e cara em determinadas regiões. Adicionalmente, a capina é realizada somente quando a competição entre as mudas e as plantas daninhas já se instalou (Toledo, 1998).

As medidas físicas adotadas no manejo de plantas daninhas em áreas florestais são de uso bastante restrito, destacando-se a utilização do fogo em situações específicas para destruição da vegetação espontânea. O calor provoca o rompimento da parede celular das plantas e conseqüentemente a inativação de enzimas, coagulando assim as proteínas.

Os incêndios controlados são comumente utilizados nas práticas silviculturais de pinus no preparo do solo para o plantio, sendo uma ferramenta de custo efetivo permitindo assim o acesso ao local para plantio, logo após a colheita da cultura. Sob condições corretas de condução, o fogo pode controlar eficientemente as plantas daninhas, limpando a área para o plantio. Nos Estados Unidos da América do Norte, normalmente, esta prática é realizada por helicópteros, que despejam combustíveis sobre a área e depois ateam fogo. Este método é usado em áreas extensas e de difícil acesso. Os benefícios no controle de plantas daninhas fogo são marginais, pois algumas sementes de plantas arbóreas, de pequena competição, morrem pela ação do fogo, reduzindo temporariamente a pressão das plantas daninhas (Mc Nabb, 1997).

Para o emprego do fogo deve ser considerado um perfeito planejamento. Em muitos lugares próximos a cidades, existe o risco de fumantes incendiarem florestas adultas, nas quais as plantas daninhas já foram controladas. A utilização do fogo pode ocasionar sérios danos a saúde humana (intoxicações, queimaduras e morte) e riscos ambientais, pois reduzem a diversidade da fauna e provocam a destruição da matéria orgânica do solo, reduzindo a produtividade local. A 
volatilização do nitrogênio é também outro fator importante na redução da produtividade de florestas. Tanto a perda da matéria orgânica, como a perda de nitrogênio devem ser seriamente consideradas na avaliação do potencial de uso do fogo nas práticas silviculturais (Mc Nabb, 1997).

Outra medida física adotada em áreas florestais é a utilização de resíduos industriais das fábricas de celulose, que além de controlar as plantas daninhas através o impedimento físico, redução da infiltração de luz e efeito químico, complementam a adubação de cobertura da cultura.

\subsubsection{Controle Químico}

O método químico de controle vem sendo cada dia mais utilizado e difundido, em razão de seus resultados de controle serem mais rápidos, eficientes e mais prolongado. O controle químico permite, ainda, o controle da comunidade infestante antes ou depois de sua emergência, com menor possibilidade de reinfestação, com conseqüente redução do número de tratos culturais e liberando a mão-de-obra, de modo a permitir uma melhor distribuição na propriedade. Por outro lado, como desvantagem do uso dessa prática de controle, menciona-se a necessidade de mão-de-obra altamente especializada e responsável, adequada orientação técnica a nível local, além do que, geralmente, o grau de controle apresentado se torna variável em função de fatores relacionados com o solo e distribuição de chuvas, entre outros. Pode, ainda, deixar resíduos no solo que venham a prejudicar o sistema de rotação de culturas e favorecer a infestação de novas plantas daninhas, devido àquebra do equ ilíbrio biológico (Toledo, 1998).

Vários trabalhos constataram a eficiência das medidas químicas no controle de plantas daninhas em espécies florestais, sendo que existe uma boa diversidade de produtos que podem ser utilizados pelas empresas florestais.

Nos últimos anos novas tecnologias têm sido empregadas pelo setor florestal brasileiro, e a utilização de herbicidas tem crescido no segmento de viveiros, na implantação da cultura, tanto em pré, como em pós-emergência, na 
pré-colheita e na renovação de áreas. Nas condições de implantação dois herbicidas são largamente empregados: em pré-emergência das plantas daninhas, o oxyfluorfen e, em pós-emergência, o glyphosate. Nas condições de campo, os herbicidas usados em pré-emergentência são aplicados com pulverizadores pressurizados costais ou tratorizados com extensões, pelas quais vários homens aplicam manualmente na linha de plantio. A complementação nas entre linhas é realizada pela aplicação tratorizada de herbicidas empregados em pósemergência, com equipamento que permite a aplicação localizada (Foloni, 1992).

A necessidade de se estudar novas técnicas de controle de plantas daninhas em espécies florestais foi sentida mais fortemente a partir do momento em que o reflorestamento avançou para a área de solos mais pobres, sobretudo os de cerrado, anteriormente ocupados com pastagens. Dentro deste contexto, vários autores inserem como alternativa o manejo integrado de plantas daninhas.

O manejo integrado das medidas de controle das plantas daninhas deve ser visto sob dois prismas distintos. No primeiro prisma o objetivo é obter maior eficiência no processo produtivo, enquanto sob o segundo prisma, o manejo integrado envolve todo um contexto em termos de planejamento global da utilização da área de integração com outras áreas. Nesse caso não existe um padrão ou seqüência de eventos edáficos, climáticos, biológicos e socio-econômicos (Pitelli, 1987).

As funções das plantas daninhas no ecossistema florestal, não foram bem estudadas e o simples controle de sua incidência e crescimento, embora relativamente fácil, não é a atitude mais inteligente da empresa florestal (Pitelli \& Marchi, 1991).

De acordo com Stape (1990), uma série de operações silviculturais, como por exemplo: preparo do solo, as fertilizações corretivas ou de manutenção e as capinas, podem influenciar positiva ou negativamente a produtividade florestal, se não atentarem a dinâmica do crescimento radicular de plantas de Eucalyptus grandis. 
Apenas após estes estudos, poderão ser elaborados verdadeiros programas de manejo de plantas daninhas em áreas de reflorestamento, onde algumas espécies (mais prejudiciais) serão controladas, enquanto que aquelas com fortes características desejáveis serão incentivadas para que ocupem o nicho ecológico, reduzindo a possibilidade de novo crescimento populacional das indesejáveis (Pitelli \& Marchi, 1991).

\subsection{Questões futuras}

Pelas considerações anteriores, é fundamental que os cientistas da área devem assumir uma postura ética de considerar o manejo integrado de plantas daninhas num contexto global de agricultura, defendendo a produção, e levando-se em conta os aspectos sociais e éticos de proteção ao ambiente (Victoria Filho, 2000).

Segundo Mc Nabb (1997), o desenvolvimento de novos herbicidas para o controle químico de plantas daninhas em áreas florestais não é considerado prioridade nas fábricas e indústrias de agroquímicos. Isto se deve ao fato de que a parcela do mercado de herbicidas destinados a florestas é muito menor do que quando comparadas com a destinada a agricultura, onde o custo de desenvolvimento de um novo produto é extremamente elevado. Nos Estados Unidos da América do Norte, é estimado que este custo desde a etapa de descoberta até o registro do herbicida é ao redor de 50 milhões de dólares. Muitas destas despesas estão associadas com os volumosos testes e estudos sobre 0 impacto ambiental que são necessários ao desenvolvimento de um herbicida aplicado em áreas florestais. Por esta razão, as pesquisas potenciais com plantas daninhas poderiam concentrar-se no melhor entendimento do uso destes produtos, como a tecnologia de aplicação.

A segunda área de pesquisas necessárias a ser proposta é a interação de herbicidas as práticas silviculturais. O estabelecimento de plantações florestais deve ser visto como um processo integrado onde um evento não pode ser 
separado do outro, pois interage e influencia na etapa seguinte. (South et al.., 1995). Como o sistema de cultivo mínimo afeta a eficácia dos herbicidas registrados na área florestal? A profundidade de plantio das espécies florestais afetaria a sensibilidade das mudas a determinados herbicidas?

Outra área de pesquisa está relacionada com o uso de genótipos resistentes a herbicida no estabelecimento de plantações florestais. O que parece ter elevado potencial no Brasil, com alguns estudos de determinados clones de eucalipto tolerantes a glyphosate, a exemplo do que acontece com variedades de soja tolerantes ao glyphosate (Roundup Ready) estudadas em todo o mundo, como produto de uma nova ciência, a biotecnologia e manipulação de genes (Mc Nabb, 1997). 


\section{FAIXAS DE CONTROLE DE PLANTAS DANINHAS E SEUS REFLEXOS NO CRESCIMENTO DO EUCALIPTO}

\section{Resumo}

Esta pesquisa foi conduzida em duas áreas florestais de Eucalyptus grandis W. Hill Ex Maiden x Eucalyptus urophylla S.T. Blake, localizadas nos municípios de Três Lagoas, MS e de Brotas, SP, no período de julho de 1996 a agosto de 2000 e de fevereiro de 1997 a março de 2001, respectivamente, com o

objetivo de avaliar os efeitos das faixas de controle das plantas daninhas sobre 0 crescimento deste clone de eucalipto. Os tratamentos experimentais constaram de dois grupos: no primeiro foram mantidas faixas fixas de controle durante os 12 meses iniciais: $0,25,50,100,125$ e $150 \mathrm{~cm}$ de cada lado da linha de plantio do eucalipto; e, no segundo, foram adotadas faixas crescentes de controle: 25 a 150, 25-50-150, 50-125-150, 100-125-150, 100 a 150 e 125 a $150 \mathrm{~cm}$. Aos 49 meses após o plantio dessas áreas, foi constatado que as plantas de eucalipto que cresceram nas parcelas com faixas de controle fixas iguais a $100 \mathrm{~cm}$ e crescentes superiores a $50 \mathrm{~cm}$ nos três primeiros meses, mostraram-se superiores, em diâmetro medido àaltura do peito (D.A.P.), altura, volume e incremento médio anual de madeira (I.M.A.).

PALAVRAS CHAVE: Brachiaria decumbens, eucalipto, manejo de plantas daninhas, competição e interferência. 


\section{WEED CONTROL STRIP AND ITS EFFECTS AT EUCALYPTUS GROWTH}

\section{Summary}

This research has been carried out in areas of Eucalyptus grandis W. Hill Ex Maiden x Eucalyptus urophylla S. T. Blake crops in Três Lagoas, Mato Grosso do Sul State and in Brotas, São Paulo State, Brazil, from July 1996 through August 2000 and from February 1997 through March 2001, respectively, to evaluate the effects of weed control in strip of different width at the Eucalyptus growth. The experiments have consisted of two groups treatments: group 1 - with a continuing width control strips have been kept throughout the first 12 months, i.e., at $0,25,50$, 100, 125 and $150 \mathrm{~cm}$ on both sides of the Eucalyptus row and, group 2: with an increasing of the width control strips has been adopted along the experimental period, i.e., at 25 to $150,25-50-150,50$ to $150,50-125-150,100-125-150,100$ tot 150 and 125 to $150 \mathrm{~cm}$ on both sides of the Eucalyptus row. After 49 months those areas were planted it was checked that the Eucalyptus plants that had grown as in the constant and as in increasing width control strips, equal to or higher than 100 and $50 \mathrm{~cm}$, respectively, has showed a higher diameter, height plant, volume and annual average increment of the wood. These results have led to the conclusion that the minimum control strip width should be $100 \mathrm{~cm}$ on both sides of the Eucalyptus row in order to keep it the weed interference.

KEY WORDS: Brachiaria decumbens, Eucalyptus, weed control, competition and interference.

\subsection{Introdução}

As áreas ocupadas pelo setor florestal é de seis milhões de hectares no Brasil, com plantio de 400 mil hectares ao ano, proporcionando em todo o país cerca de 1,2 milhões de empregos diretos, sendo responsável por $4 \%$ do produto interno bruto, faturando em torno de 15 bilhões de dólares por ano e exportando anualmente dois bilhões de dólares. Apesar dessa magnitude, deve-se salientar que, para garantir sua sustentabilidade e competitividade, o setor depende, dentre 
outros fatores, de uma base florestal que atenda a padrões cada vez mais exigentes em termos de qualidade e produtividade, o que conduz ao efetivo investimento em pesquisa e adoção de práticas silviculturais adequadas (Toledo, 1999).

Nas últimas décadas, os cientistas das plantas daninhas vêm estudando os efeitos da interferência destas plantas sobre o crescimento e a produtividade do eucalipto. Dentre os efeitos desta interferência, pode-se destacar a competição por água, luz e nutrientes e a interferência de natureza alelopática, a atuação como hospedeiras intermediárias de pragas e patógenos e o aumento de riscos de incêndios. Além desses fatores, há, também, o aumento progressivo nos custos da mão-de-obra necessária para as operações de limpeza e manutenção da floresta (Toledo et al., 1996). Segundo Pitelli \& Marchi (1991), a interferência imposta pelas plantas daninhas é mais severa principalmente na fase inicial de crescimento, ou seja, do plantio até cerca de um ano de idade das plantas de eucalipto.

É importante ressaltar que o setor florestal tem se expandido em áreas de cerrado, as quais eram anteriormente ocupadas com pastagens, especialmente de Brachiaria decumbens. Assim, esta planta, devido àsua ele vada agressividade e ao seu difícil controle, tornou-se uma das infestantes mais problemáticas nos plantios comerciais de eucalipto (Toledo et al., 2000a).

O manejo das plantas daninhas em áreas florestais, nas diversas etapas do seu processo produtivo, é realizado, basicamente, pelo emprego de métodos mecânicos e químicos, isolados ou combinados. Dentre os herbicidas utilizados em áreas florestais, destacam-se principalmente oxyfluorfen e glyphosate, sendo este último utilizado em grande escala, pelo fato de ser usado em pós-emergência das plantas daninhas, facilitando o plantio em áreas de cultivo mínimo (Toledo, 1998).

A pesquisa teve como objetivo estudar o efeito da variação na largura da faixa de controle de Brachiaria decumbens Stapf sobre o crescimento de florestas 
homogêneas de Eucalyptus grandis W. Hill ex Maiden x Eucalyptus urophylla S.T. Blake, nos municípios de Três Lagoas, MS e Brotas, SP.

\subsection{Material e Métodos}

A pesquisa foi conduzida em duas áreas florestais pertencentes a International Paper do Brasil Ltda., localizadas nos municípios de Três Lagoas, MS e de Brotas, SP, no período de julho de 1996 a agosto de 2000 e fevereiro de 1997 a março de 2001, respectivamente.

As áreas experimentais foram selecionadas quanto à uniformidade na infestação de plantas daninhas, sendo esta representativa das áreas de produção da empresa florestal. A área localizada em Três Lagoas, MS era anteriormente cultivada com pastagens de Brachiaria decumbens, enquanto que a de Brotas, SP era área de reforma de eucalipto. Em levantamento prévio, pela técnica de amostragens aleatórias, foi constatado que as populações mais freqüentes nessas áreas foram o capim-braquiária ( $B$. decumbens), a erva-quente (Spermacoce latifola Aubl.) e algumas rebrotas de cerrado, enquanto em Brotas, SP, além destas, foram o capim-favorito (Rhynchelytrum repens (Willd.) Hubbart), o capimamargoso (Digitaria insularis (L.) Mez ex Ekman), o capim-gordura (Melinis minutiflora Beauv.), a tiririca (Cyperus rotundus L.), o cipó-de-São-João (Pyrestegia venusta Miers.) e rebrotas de eucalipto.

No município de Três Lagoas foi efetuada inicialmente a derrubada de árvores esparsas, àpassagem de uma gradagem dupla com máquina pesada e de uma gradagem média em área total. Em seguida, foram realizadas a abertura dos sulcos e a adubação de plantio, a qual constituiu na distribuição, ao longo do sulco, do adubo N-P-K na fórmula 08-32-16 + micronutrientes (0,3 \% Zn, 0,07 \% Cu e 0,5 $\%$ B), em quantidade equivalente a $140 \mathrm{~kg} \cdot \mathrm{ha}^{-1}$.

Em Brotas, SP, inicialmente foi efetuado o controle das plantas daninhas pela aplicação de $1,08 \mathrm{~kg}$ e.a./ha de glyphosate em área total, utilizando um pulverizador tratorizado, munido de bicos Teejet 110.02, regulado para um 
consumo de calda de 300 L.ha. Em seguida, foi realizado o preparo da área com gradagem média e posterior abertura dos sulcos, calagem (1 tonelada de calcário dolomítico/ha) e a adubação de plantio, que constituiu da distribuição, ao longo do sulco, do adubo NP-K na fórmula 10-30-10, em quantidade equivalente a 120 kg.ha ${ }^{-1}$.

Aos 4 e 18 meses após o plantio da área de Brotas, SP foram realizadas as adubações de cobertura, que constituíram na distribuição, ao longo do sulco, de $120 \mathrm{~kg} \cdot$ ha $^{-1}$ do adubo N-P-K nas fórmulas 10-30-10 e 14-00-28, respectivamente.

As mudas de eucalipto foram provenientes de micropropagação. $O$ clone utilizado é um híbrido resultante do cruzamento entre E. grandis W. Hill ex Maiden com E. urophylla S.T. Blake muito cultivado em função de seu rápido crescimento, associado à sua tolerância a longos períodos de estiagem. As mudas, com cerca de 100 dias de idade, foram plantadas em Três Lagoas, MS no espaçamento de 3,0 m entre plantas e 3,0 m na entre linha de plantio, enquanto em Brotas, SP foi utilizado o espaçamento de 2,5 m x 3,0 m.

As parcelas experimentais foram constituídas por seis linhas de plantio com oito plantas cada, totalizando $432 \mathrm{~m}^{2}$ de área total em Três Lagoas, MS e 360 $\mathrm{m}^{2}$ em Brotas, SP, sendo duas linhas externas de cada lado e duas plantas nas extremidades das linhas internas consideradas bordadura, totalizando 72 e $60 \mathrm{~m}^{2}$ de área útil, respectivamente.

Os tratamentos experimentais constaram de diferentes extensões da largura da faixa de controle das plantas daninhas de cada lado da linha de plantio das mudas de eucalipto (Tabela 1). Esses tratamentos podem ser divididos em dois grupos: no primeiro foram mantidas faixas constantes de controle durante os doze meses iniciais: 0, 25, 50, 100, 125 e $150 \mathrm{~cm}$ de cada lado da linha de plantio. No segundo foram adotadas faixas crescentes de controle: 25 a 150, 25-50-150, 50 a 150,50-125-150, 100-125-150, 100 a 150 e 125 a $150 \mathrm{~cm}$. no decorrer do período experimental, de acordo com estudo sobre a influência da interação da 
adubação e o crescimento radicular do eucalipto sobre a produtividade florestal realizado por Stape (1990), sendo a metodologia adaptada por Toledo (1998).

No campo, os tratamentos foram dispostos no delineamento experimental de blocos ao acaso, com quatro repetições. Os dados obtidos foram submetidos ao teste $\mathrm{F}$ aplicado à análise de variância e as médias individuais confrontadas pelo teste de comparação múltipla de Tukey ao nível de $5 \%$ de probabilidade. Os diferentes grupos de tratamentos foram comparados por contrastes ortogonais de interesse, conforme descritos na Tabela 2.

As faixas de controle das plantas daninhas foram mantidas por meio de capina manual, utilizando-se de um sistema de balizamento com estacas para facilitar a operação, conforme metodologia proposta por Toledo (1998).

Tabela 1. Variações da largura da faixa de controle das plantas daninhas durante os meses de agosto a julho que constituíram os tratamentos experimentais. Três Lagoas, M.S e Brotas, SP.

\begin{tabular}{|c|c|c|c|c|c|c|c|c|c|c|c|c|}
\hline \multicolumn{13}{|c|}{ MESES APÓS O PLANTIO. } \\
\hline Trat. & $1^{\circ}$ & $2^{\circ}$ & $3^{\circ}$ & $4^{\circ}$ & $5^{\circ}$ & $6^{\circ}$ & $7^{\circ}$ & $8^{\circ}$ & $9^{\circ}$ & $10^{\circ}$ & $11^{\circ}$ & $12^{\circ}$ \\
\hline T1. & 0 & 0 & 0 & 0 & 0 & 0 & 0 & 0 & 0 & 0 & 0 & 0 \\
\hline T2. & $25^{1}$ & 25 & 25 & 25 & 25 & 25 & 25 & 25 & 25 & 25 & 25 & 25 \\
\hline T3. & 50 & 50 & 50 & 50 & 50 & 50 & 50 & 50 & 50 & 50 & 50 & 50 \\
\hline T4. & 100 & 100 & 100 & 100 & 100 & 100 & 100 & 100 & 100 & 100 & 100 & 100 \\
\hline T5. & 125 & 125 & 125 & 125 & 125 & 125 & 125 & 125 & 125 & 125 & 125 & 125 \\
\hline T6. & 150 & 150 & 150 & 150 & 150 & 150 & 150 & 150 & 150 & 150 & 150 & 150 \\
\hline T7. & 25 & 50 & 100 & 125 & 150 & 150 & 150 & 150 & 150 & 150 & 150 & 150 \\
\hline T8. & 25 & 50 & 50 & 100 & 125 & 150 & 150 & 150 & 150 & 150 & 150 & 150 \\
\hline T9. & 50 & 50 & 100 & 125 & 150 & 150 & 150 & 150 & 150 & 150 & 150 & 150 \\
\hline T10. & 50 & 50 & 50 & 125 & 125 & 150 & 150 & 150 & 150 & 150 & 150 & 150 \\
\hline$T 11$. & 100 & 100 & 100 & 125 & 150 & 150 & 150 & 150 & 150 & 150 & 150 & 150 \\
\hline$T 12$. & 100 & 100 & 100 & 100 & 150 & 150 & 150 & 150 & 150 & 150 & 150 & 150 \\
\hline T13. & 125 & 125 & 125 & 125 & 150 & 150 & 150 & 150 & 150 & 150 & 150 & 150 \\
\hline
\end{tabular}

${ }^{1}$. Faixa de controle das plantas daninhas em $\mathrm{cm}$ de cada lado da linha de plantio.

No ensaio localizado em Três Lagoas, MS foram avaliadas as oito plantas de eucalipto da área útil de cada parcela experimental quanto à altura aos 17 meses de idade. Aos 22, 33 e 49 meses de idade foram mensurados também, o 
diâmetro médio medido a altura do peito (D.A.P.), a altura dessas plantas, o volume médio e o incremento médio anual de madeira (I.M.A.). Enquanto em Brotas, SP essas avaliações foram realizadas aos 13, 24, 37 e 49 meses após o plantio. 
Tabela 2. Descrição dos contrastes ortogonais de interesse, utilizados nos ensaios de faixas de controle das plantas daninhas e seus reflexos na produtividade do eucalipto. Três Lagoas, MS e Brotas, SP.

\begin{tabular}{|c|c|}
\hline CONTRASTES & DESCRIÇÃO \\
\hline$Y(1)$ & Faixas fixas de 0 a $50 \mathrm{~cm}$ (T1 a T3) X Faixas fixas de 100 a $150 \mathrm{~cm}(\mathrm{~T} 4$ a T6) \\
\hline$Y(2)$ & Testemunha sem controle (T1) X Faixa fixa de $50 \mathrm{~cm}(\mathrm{~T} 3)$ \\
\hline$Y(3)$ & Faixa fixa de $50 \mathrm{~cm}(\mathrm{~T} 3) \times$ Faixa fixa de $100 \mathrm{~cm}(\mathrm{~T} 4)$ \\
\hline$Y(4)$ & Faixa fixa de $100 \mathrm{~cm}(\mathrm{~T} 4) \times$ Testemunha no Limpo $(\mathrm{T} 6=150 \mathrm{~cm})$ \\
\hline$Y(5)$ & Faixa fixa de $50 \mathrm{~cm}$ (T3) X Faixa crescente que iniciou com $25 \mathrm{~cm}$ (T7) \\
\hline$Y(6)$ & Faixas crescentes com 25 e $50 \mathrm{~cm}$ (T7 a T10)x Faixas crescentes com 100 a $150 \mathrm{~cm}$ (T11 a T13) \\
\hline$Y(7)$ & Faixa fixa de $100 \mathrm{~cm}$ (T4) x Faixa crescente que iniciou com $25 \mathrm{~cm}$ (T7) \\
\hline$Y(8)$ & Faixa fixa de $50 \mathrm{~cm}$ (T3) x Faixa crescente que iniciou com $50 \mathrm{~cm}$ (T9) \\
\hline$Y(9)$ & Faixas fixas de $100 \mathrm{~cm}$ até os $3^{0}$ meses (T11) x Faixas fixas de $125 \mathrm{~cm}$ até os $3^{0}$ meses (T13) \\
\hline$Y(10)$ & Faixa fixa de $100 \mathrm{~cm}$ (T4) x Faixas crescentes que iniciaram com $50 \mathrm{~cm}$ (T9 e T10) \\
\hline
\end{tabular}


$\mathrm{Na}$ área útil de cada parcela experimental foi amostrado $1,5 \mathrm{~m}^{2}$ da comunidade infestante, correspondendo a seis amostras de $0,25 \mathrm{~m}^{2}$, das quais três amostras foram realizadas na linha e três na entre linha de plantio. As espécies de plantas daninhas presentes foram identificadas, contadas e levadas ao laboratório do Departamento de Biologia Aplicada à Agropecuária da Faculdade de Ciências Agrárias e Veterinárias de Jaboticabal, UNESP, onde foram lavadas e secas em estufa com renovação forçada de ar a $70{ }^{\circ} \mathrm{C}$ por 96 horas. Após este procedimento, foi determinada a biomassa seca da parte aérea das plantas coletadas, utilizando balança eletrônica com precisão de 0,01 g.

\subsection{Resultados e Discussão}

As principais espécies de plantas daninhas presentes em Três Lagoas, MS foram o capim-braquiária (Brachiaria decumbens Stapf) e a erva-quente (Spermacoce latifola Aubl.). O capim-braquiária foi à pop ulação predominante nesta área, acumulando, em média, a $241 \mathrm{~g} \cdot \mathrm{m}^{-2}$, correspondendo a 89\% da biomassa seca acumulada na área total da parcela da testemunha "no mato", distribuída da seguinte forma: $98 \mathrm{~g} \cdot \mathrm{m}^{-2}$ na linha e $143 \mathrm{~g} \cdot \mathrm{m}^{-2}$ na entrelinha de plantio do eucalipto. Por outro lado, a erva-quente correspondeu em média $38 \mathrm{~g} . \mathrm{m}^{-2}$, sendo $4 \mathrm{~g} \cdot \mathrm{m}^{-2}$ na linha e $34 \mathrm{~g} \cdot \mathrm{m}^{-2}$ na entrelinha de plantio (Figura 1).

A densidade média do capim-braquiária observada durante o período experimental em Três Lagoas, MS, foi de 27 plantas. $m^{-2}$ na área total das parcelas, divididas em 8 plantas. $\mathrm{m}^{-2}$ na linha e 19 plantas. $\mathrm{m}^{-2}$ na entrelinha de plantio do eucalipto. A densidade da erva-quente foi de 6 plantas. $\mathrm{m}^{2}$, com 4 plantas. $\mathrm{m}^{-2}$ na linha e 2 plantas. $\mathrm{m}^{-2}$ na entrelinha da cultura, conforme pode ser observado na Figura 2. 

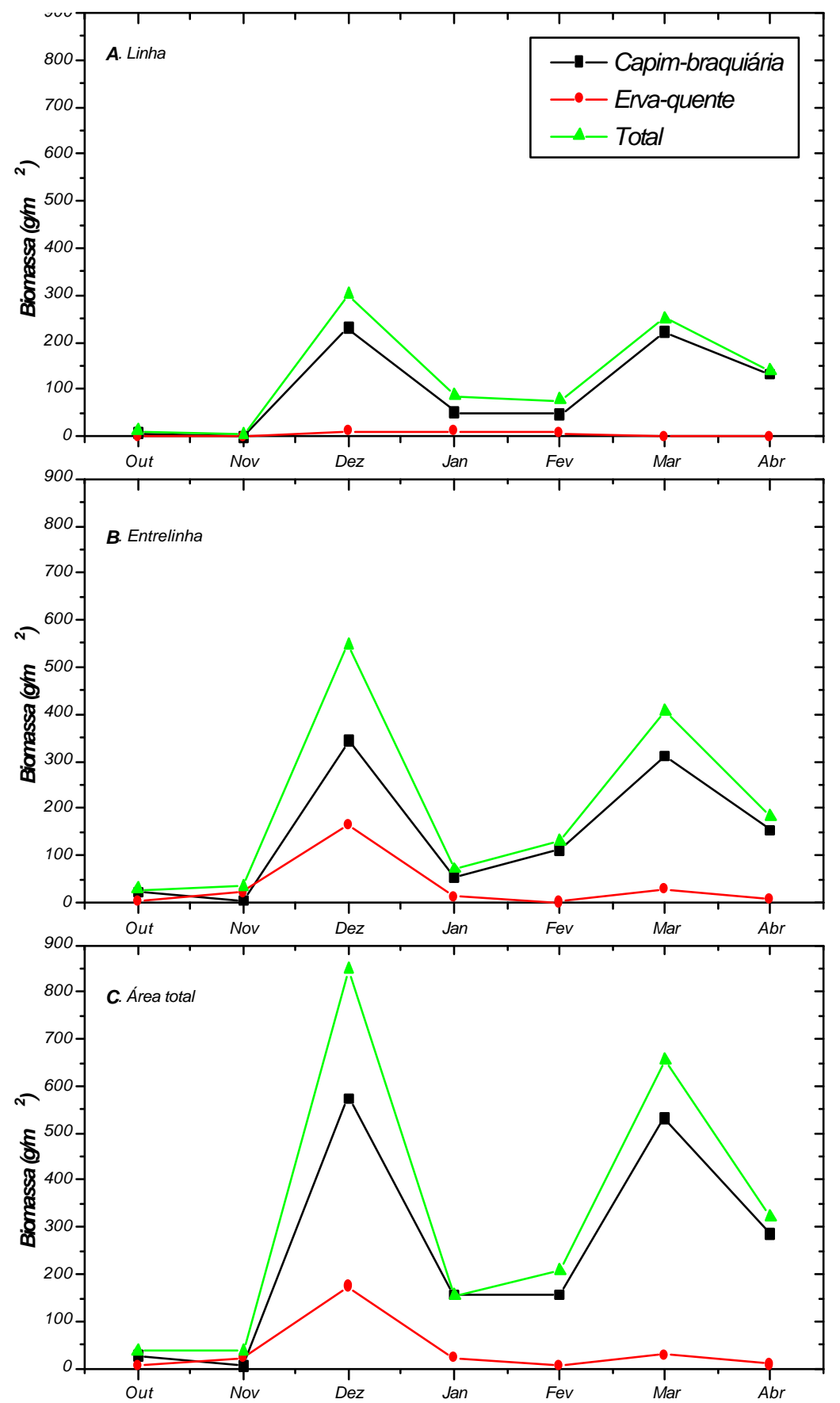

Figura 1- Biomassa seca acumulada $\left(\mathrm{g} \cdot \mathrm{m}^{-2}\right.$ ) pelas principais populações de plantas daninhas na linha $(A)$, na entrelinha $(B)$ e na área total $(C)$ da cultura do eucalipto em diferentes épocas de amostragens. Três Lagoas, MS. 
As monocotiledôneas como o capim-braquiária, o capim-favorito (Rhynchelitrum repens (Willd.) Hubbart), o capim-amargoso (Digitaria insularis (L.) Mez ex Ekman), o capim-gordura (Melinis minutiflora Beauv.) e a tiririca (Cyperus rotundus L.) foram æ̀ populaçõ es mais freqüentes em Brotas, SP, acumulando, em média, $413 \mathrm{~g} \cdot \mathrm{m}^{-2}$ da biomassa seca na área total da parcela da testemunha "no mato", distribuída $99 \mathrm{~g} \cdot \mathrm{m}^{-2}$ na linha e $314 \mathrm{~g} \cdot \mathrm{m}^{-2}$ na entrelinha de transplante do eucalipto após 364 dias de livre crescimento. Por outro lado, as demais espécies componentes da comunidade infestante: erva-quente, cipó-de-São-João (Pyrestegia venusta Miers.) e algumas rebrotas de cerrado, acumularam em média $227 \mathrm{~g} \cdot \mathrm{m}^{-2}$, sendo $13 \mathrm{~g} \cdot \mathrm{m}^{-2}$ na linha e $214 \mathrm{~g} \cdot \mathrm{m}^{-2}$ na entre linha de plantio (Figura 2).

A densidade média da comunidade infestante nas parcelas em que as plantas de eucalipto conviveram por 364 dias com as plantas daninhas foi de 44 plantas. $\mathrm{m}^{-2}$ na área total, distribuídas em 8 plantas. $\mathrm{m}^{-2}$ na linha e 36 plantas. $\mathrm{m}^{2}$ na entrelinha de plantio do eucalipto (Figura 2). Já a densidade média das monocotiledôneas na área total das parcelas foi de 28 plantas. $\mathrm{m}^{-2}$, distribuídas em 6 plantas. $\mathrm{m}^{-2}$ na linha e 22 plantas. $\mathrm{m}^{-2}$ na entre linha da cultura, enquanto a densidade de dicotiledôneas foi 16 plantas. $\mathrm{m}^{-2}$, com 2 plantas. $\mathrm{m}^{-2}$ na linha e 14 plantas. $m^{-2}$ na entre linha da cultura.

Bezutte et al., (1995) observaram que a partir de 4 plantas. ${ }^{-2}$, o capimbraquiária interfere significativamente no crescimento inicial das mudas de eucalipto, reduzindo em média $28 \%$ o diâmetro do caule e $18 \%$ a altura das plantas, aos 190 dias após o plantio. 

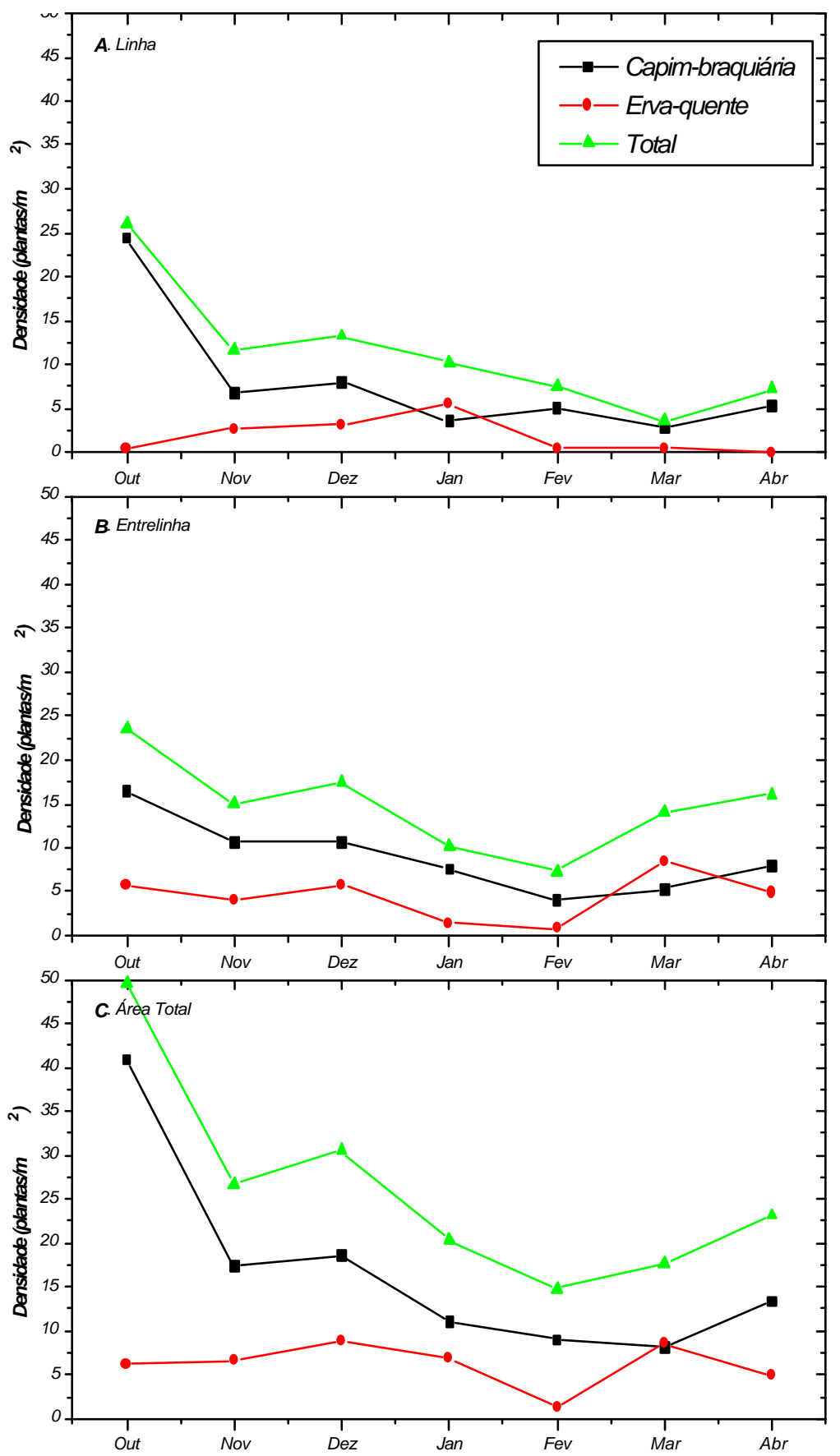

Figura 2 - Densidade média (plantas. $\mathrm{m}^{-2}$ ) das principais populações de plantas daninhas na linha $(A)$, na entrelinha $(B)$ e na área total $(C)$ da cultura do eucalipto em diferentes épocas de amostragens. Três Lagoas, M.S.

Conforme Costa (1999), a partir de 4 plantas.m-2, a erva-quente já interfere negativamente sobre o crescimento inicial do eucalipto, reduzindo em média 
$44,4 \%$ da área foliar, 35,2\% e 42,2\% da biomassa seca de caule e de ramos nas condições de inverno, enquanto nas condições de verão, essas reduções foram $20,6 \%$ no diâmetro do caule, $34,1 \%$ e $33,1 \%$ no número de folhas e ramos, $50,8 \%$ na área foliar, 33,4\%, 49,5\% e 48,3\% na biomassa seca do caule, ramos e folhas. Pelos dados da literatura apresentada pode-se inferir que as densidades médias observadas nas áreas experimentais justificam a necessidade de controle das plantas daninhas.

Quando se considera o período de 22 a 49 meses após o plantio em Três Lagoas, MS, as reduções médias observadas em altura (29,7\%, $19,3 \%$ e $0,6 \%$ ) e D.A.P $(35,1 \%, 19,0 \%$ e $1,0 \%)$ das plantas de eucalipto indicam interferências menores das plantas daninhas neste período, o que sugere a hipótese de recuperação das plantas de eucalipto em fases mais avançadas do ciclo da cultura (Tabela 3). Todavia, segundo Toledo et al. (2000b), comparando æ̀ médias da testemunha "no mato" e dos tratamentos de faixas fixas de controle de 50 e $100 \mathrm{~cm}$ de cada lado da linha de plantio da cultura contra a média da estemunha "no limpo" observa-se que as porcentagens de redução, no período de 7 a 13 meses após o plantio em Três Lagoas, MS, foram de 39,9\%, 28,9\% e 8,8\% em relação à altura e de 44,1\%, 29,1\% e 8,9\% em relação ao diâmetro do caule das plantas de eucalipto, respectivamente, demonstrando severa interferência das plantas daninhas no primeiro ano de desenvolvimento da cultura do eucalipto. 

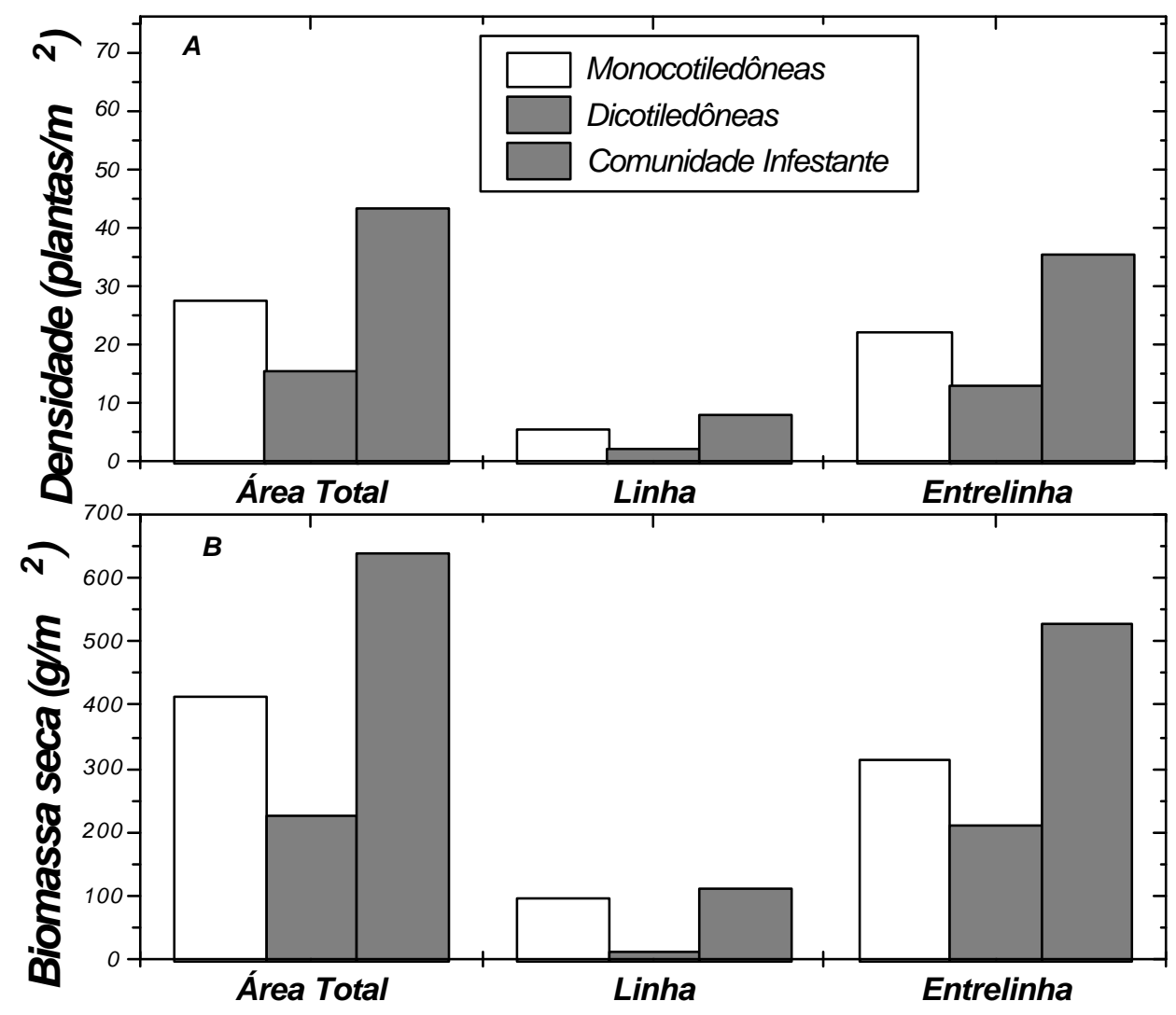

Figura 3 - Densidade média (plantas. $\mathrm{m}^{-2}$ - A) e biomassa média seca acumulada (g.m $\mathrm{m}^{-2}$ - B) pelas principais populações de plantas daninhas presentes na área experimental aos 364 dias após o plantio. Brotas, SP. 
Já em relação aos dados da estimativa da produtividade da cultura observase aos 33 meses após o plantio em Três Lagoas, MS que as plantas de eucalipto que conviveram com a comunidade infestante (testemunha "no mato") e nas parcelas nas quais as plantas daninhas foram controladas em faixas fixas de $50 \mathrm{e}$ $100 \mathrm{~cm}$ apresentaram variações relativas médias em volume e de I.M.A. de madeira de $-51,4 \%,-14,5 \%$ e $11,1 \%$, respectivamente, enquanto aos 49 meses após o plantio esses valores foram de $-1 \%,-11,5 \%$ e 3,1\%, quando comparadas com as plantas da testemunha "no limpo" (Tabela 3), fato que novamente sugere uma recuperação das plantas de eucalipto.

$\mathrm{Na}$ área de Brotas, SP, comparando a média da testemunha "no mato" e dos tratamentos de faixas fixas de controle de 50 e $100 \mathrm{~cm}$ contra a média da testemunha "no limpo", observa-se que as porcentagens de redução aos 13 meses foram $-27,1 \%$, $-22,7 \%$ e $-5,6 \%$ em altura e $-21,4 \%,-23,1 \%$ e $-7,9 \%$ em D.A.P. No entanto, quando se considera o período de 24 aos 49 meses após o plantio foram obtidas variações relativas de: $-1,6 \% ;-5,9 \%$ e $3,2 \%$ em altura e $6,1 \%,-2,6 \%$ e 10,9\% em D.A.P. (Tabela 4), o que sugere a recuperação da cultura a interferência da comunidade infestante. Esta recuperação também pode ser inferida da observação de que os efeitos da interferência das plantas daninhas sobre o D.A.P. apenas foram significativos até os 24 meses após o plantio. Todavia, quando se considera a altura do eucalipto esses efeitos foram observados até os 37 meses após o plantio (Tabelas 4 e 5).

Quando se analisa essa estimativa para a região de Brotas, SP pode-se observar $-4,7 \%$ e $-19,3 \%$ no volume e I.M.A. de madeira das plantas de eucalipto que cresceram na testemunha "no mato" e na faixa de controle fixa de $50 \mathrm{~cm}$ e $23,7 \%$ e 23,7 em volume e I.M.A. das plantas da faixa fixa de $100 \mathrm{~cm}$ quando comparadas àtestemunha "no limpo" (Tabela 4).

De acordo com Gonçalves et al. (2000) nos três primeiros meses de crescimento das mudas de eucalipto no campo as taxas de absorção de nutrientes são pequenas. Neste período, as mudas de eucalipto alocam grande quantidade 
de fotoassimilados e nutrientes para o crescimento de raízes para assegurar o suprimento de água e nutrientes. Por este motivo, se desenvolvem menos, e podem mostrar sintomas de deficiências nutricionais.

Posteriormente, com os suprimentos de água e nutrientes assegurados, a atividade fotossintética é intensificada, havendo grande expansão da área foliar e maior crescimento epígeo das mudas de eucalipto. A seguir ocorre uma fase de intenso crescimento e acúmulo de nutrientes, com elevadas taxas de absorção que se relacionam diretamente com a idade da cultura. Neste período, as plantas de eucalipto estão mais sensíveis a competição das plantas daninhas, pois todos os fotoassimilados são sintetizados para a formação de copas (expansão da área foliar) e sistema radicular, principalmente raízes finas (raízes com função de absorção de água e nutrientes). O sistema radicular explora parcialmente o volume do solo e as árvores não competem entre si por fatores de crescimento (luz, nutrientes, espaço e água), sendo seu crescimento limitado pelas próprias condições fisiológicas e pelos inimigos naturais, incluindo as plantas daninhas (Gonçalves et al., 2000).

A intensa resposta à fertilização neste estágio de desenvolvimento é muito comum. Nestas situações, as taxas de absorção de nutrientes e a atividade metabólica dos componentes das árvores são elevadas, podendo ser aumentados o tempo de retenção das folhas e a eficiência fotossintética por unidade de área foliar (Gonçalves et al., 2000).

Sob baixas disponibilidades de água e nutrientes, as plantas daninhas podem competir com as plantas de eucalipto, podendo gerar deficiências principalmente na fase de estabelecimento das florestas. Uma das razões do grande poder competitivo dessas plantas daninhas está relacionada a grande capacidade de adaptação das populações infestantes às condições ambientais do sítio (Silva et al., 1997). Portanto, pode-se justificar o efeito mais severo das plantas daninhas nas fases iniciais de desenvolvimento do eucalipto. 
Pelo estudo do contraste $Y(1)$ foi possível observar que as plantas de eucalipto que permaneceram livres das plantas daninhas numa faixa de até $50 \mathrm{~cm}$ (T1 a T3) apresentaram menores alturas e D.A.P., a partir dos 17 aos 49 meses em Três Lagoas, MS e dos 13 aos 37 meses em Brotas, SP, quando comparadas com as plantas de eucalipto das parcelas nas quais as faixas de controle foram iguais ou superiores a $100 \mathrm{~cm}$ (T4 a T6). Na Tabela 5, pode-se observar nas duas áreas que a testemunha "no mato" ( $(T 1)$ e as faixas fixas de controle de 25 e $50 \mathrm{~cm}$ (T2 e T3) apresentaram menores valores de altura e de D.A.P. em relação às faixas fixas de 100 a $150 \mathrm{~cm}$ (T4 a T6) e que os tratamentos de faixas fixas de controle de 100 a $150 \mathrm{~cm}$ (T4 a T6) e de faixas crescentes de que iniciaram com 100 a $125 \mathrm{~cm}$ (T11 a T13) apresentaram os maiores valores para altura e D.A.P. das plantas, respectivamente.

Toledo et al. (2000b) verificaram na região de Três Lagoas, MS, pelo contraste $\mathrm{Y}(2)$ até os 13 meses após o plantio da cultura que as plantas que conviveram com a comunidade infestante (T1) não apresentaram diferença em diâmetro do caule e altura das plantas do tratamento de faixa constante de $50 \mathrm{~cm}$ (T3), padrão adotado por diversas empresas florestais. No entanto, dos 33 até 49 meses após o plantio, essas plantas tenderam a apresentar menor D.A.P. e altura do que as plantas do tratamento de faixa constante de $50 \mathrm{~cm}$ (T3), embora essa diferença não tenha sido significativa (Tabelas 5 e 6 ).

$\mathrm{Na}$ região de Brotas, SP, pode-se observar pelo estudo desse contraste (Y2) que as plantas de eucalipto da testemunha "no mato" não apresentaram diferença significativa em D.A.P. e altura das plantas de eucalipto das parcelas de faixa constante de $50 \mathrm{~cm}$ (T3), padrão adotado por diversas empresas florestais, dos 13 aos 47 meses após o plantio (Tabelas 5 e 7).

As plantas de eucalipto que cresceram nas parcelas de faixa fixa de $50 \mathrm{~cm}$ (T3) apresentaram D.A.P. menores aos 22 meses em Três Lagoas, MS e dos 24 aos 37 meses após o plantio em Brotas, SP quando comparadas com as plantas das parcelas que receberam a faixa fixa de controle de $100 \mathrm{~cm}$ (T4 - contraste Y3). 
No entanto, em altura essa diferença pode ser observada dos 17 aos 49 meses, em Três Lagoas, MS e dos 13 aos 49 meses após o plantio em Brotas, SP (Tabela 5).

As plantas de eucalipto de ambas as regiões que cresceram sob as faixas constantes de controle de 100 e $150 \mathrm{~cm}$, contraste $\mathrm{Y}(4)$, não apresentaram diferença significativa entre si, em relação ao D.A.P. e altura dos 17 aos 49 meses (Tabelas 5 e 7). Esses resultados confirmam os obtidos por Toledo et al., (2000).

Silva (1999) ao estudar o efeito das faixas de controle das plantas daninhas no desenvolvimento inicial do eucalipto nas regiões de Araraquara e Altinópolis, SP, sob forte interferência do capim-colonião e do capim-favorito, respectivamente, observou que as faixas de controle a partir de 50 e $75 \mathrm{~cm}$ de cada lado da linha de plantio de Eucalyptus grandis foram æ̀s faixas que proporcionaram maiores valores de altura, diâmetro do caule e taxa de crescimento absoluto tanto em altura como em diâmetro até os 13 meses após o plantio.

Essas diferenças podem ser explicadas de acordo com o modelo esquemático proposto por Bleasdale ${ }^{10}$ e adaptado por Pitelli (1985), que considera vários fatores que afetam o grau de interferência entre a cultura do eucalipto e a comunidade infestante. Segundo este esquema, o grau de interferência depende das manifestações de fatores ligados à própria cultura (espécie, variedade ou clone e espaçamento de plantio), àcomunidade infestante (composição específica, densidade e distribuição) e a época e extensão do período de convivência. Além disso, pode ser alterado pelas condições climáticas, edáficas e dos tratos culturais.

Toledo (1999), considera que dada à diversidade desses fatores e aos períodos de interferência e a complexidade dessa interação torna-se extremamente importante que novos estudos sejam realizados com convênios

${ }^{10}$ BLEASDALE, J.K. Studies on plant competition. In: PITELLI, R.A.. Informe Agropecuário. v.11, n.129, p. 16-27, 1985. 
entre as universidades e as empresas florestais que necessitem de informações mais próximas ao seu ambiente específico, pois todos os componentes e condições variam, em graus diversos, com o tempo e de região para região. As várias condições podem ser mais ou menos expressivas, dependendo das plantas daninhas presentes e da prática silvícola empregada (Pitelli, 1985).

A partir dos 10 e até os 13 meses após o plantio, as plantas de eucalipto que cresceram nas parcelas nas quais as plantas daninhas foram controladas com faixa fixa de $50 \mathrm{~cm}$ (T3) em Três Lagoas, MS, apresentaram menores diâmetros de caule do que as plantas das parcelas nas quais utilizou-se a faixa de controle crescente inicial de $25 \mathrm{~cm}$ (T7) (Toledo et al., 2000b). Todavia, quando se analisa a altura do eucalipto, pode-se observar pelo contraste $Y(5)$ que essa diferença significativa manifestou no período de 17 aos 49 meses após o plantio (Tabela 5).

No entanto, para a região de Brotas, SP, as plantas de eucalipto das parcelas de faixa fixa de $50 \mathrm{~cm}$ (T3) apresentaram menores D.A.P. e altura quando comparadas as plantas das parcelas de faixa crescente inicial de $25 \mathrm{~cm}$ (T7) somente aos 13 meses (Contraste Y(5) - Tabela 5).

Para as faixas crescentes de controle, foi observado que as plantas de eucalipto da região de Três Lagoas, MS, que receberam controle inicial de 25 e 50 $\mathrm{cm}$ apresentaram menores valores de altura e D.A.P. quando comparadas æ̀ plantas das faixas crescentes que iniciaram com 100 e $125 \mathrm{~cm}$ - contraste $Y(6)$ - de acordo com as Tabelas 5 e 6, enquanto para a região de Brotas, SP não apresentaram diferença significativa, sendo recomendado à utilização das faixas crescentes de controle a partir de $25 \mathrm{~cm}$ no manejo de plantas daninhas.

Pelo estudo do contraste Y(7) é possível afirmar para ambas as regiões que as plantas de eucalipto das parcelas de faixa fixa de $100 \mathrm{~cm}$ não apresentaram diferença significativa em altura e D.A.P. quando comparadas æ̀ plantas da faixa crescente inicial de $25 \mathrm{~cm}$ durante o período experimental (Tabela 5).

Pelo contraste $\mathrm{Y}(8)$, ao confrontar os valores de diâmetro do caule das plantas de eucalipto de Três Lagoas, MS da faixa fixa de $50 \mathrm{~cm}$ (T3) com a faixa 
crescente inicial de $50 \mathrm{~cm}$ (T9) obtidos por Toledo (1998) pode-se observar diferença significativa no período de 10 aos 13 meses após o plantio (contraste $Y(8)$ ). No entanto, quando se considera a altura e o D.A.P. dessas plantas de eucalipto avaliadas respectivamente a partir dos 17 e 22 meses após o plantio, essa diferença significativa é observada para D.A.P. somente aos 22 meses, enquanto que para altura no período de 17 aos 49 meses em Três Lagoas, MS e aos 37 meses em Brotas, SP (Tabelas 5 a 7 ).

Até 49 meses, não foi observada diferença significativa em relação ao D.A.P. e altura das plantas de eucalipto das duas regiões de plantio entre os tratamentos nos quais se manteve uma faixa de 100 e $125 \mathrm{~cm}$ durante os três meses iniciais (Contraste $\mathrm{Y}(9)$ ), conforme pode ser observado na Tabelas 3.5.

Com relação às taxas de crescimento absoluto avaliadas por Toledo et al. (2000) na região de Três Lagoas, MS, pode-se constatar aos 9 meses, apenas tendência de que as faixas fixas de controle de $100 \mathrm{a} 150 \mathrm{~cm}$ e as faixas crescentes promoveram maior crescimento em diâmetro do caule do eucalipto, quando comparadas com a testemunha não capinada ("no mato") e as faixas constantes de 25 e $50 \mathrm{~cm}$. Para a altura das plantas essa tendência foi observada apenas a partir dos 9 meses, fato que pode ser explicado pelo estiolamento das plantas de eucalipto quando na presença de plantas daninhas, em função da interceptação inicial de luz.

Segundo Pitelli \& Marchi (1991), a competição por luz é uma das modalidades de interferência que provoca maior impacto sobre o crescimento do eucalipto, pois restringe a fonte predominante de energia aos processos básicos de recrutamento de elementos e de elaboração de todas as substâncias envolvidas no crescimento do vegetal. Em algumas situações, as plantas daninhas também podem modificar a característica de crescimento das espécies florestais, promovendo estiolamento e proporcionando suporte mecânico. Esta situação permite que a planta ganhe altura rapidamente e reduza o espessamento do caule, 
tornando-se mais suscetível ao tombamento, quando a comunidade infestante for controlada.

De acordo com Toledo et al., (2000b), a partir dos 9 meses após o plantio em Três Lagoas, MS, os efeitos das diferentes faixas de controle da comunidade infestante começaram a se sobressair, ou seja, as plantas de eucalipto das parcelas de faixas fixas de 100 a $150 \mathrm{~cm}$ (T4 a T6) e das faixas crescentes (T7 a T13) mostraram-se com maiores valores de diâmetro do caule e altura. Já aos 22 meses, as plantas de eucalipto das parcelas que foram mantidas em área total, em faixas fixas a partir de $100 \mathrm{~cm}$ e em faixas crescentes que iniciaram com 50, $100 \mathrm{e}$ $125 \mathrm{~cm}$ de controle das plantas daninhas mostraram-se superiores æ̀̀ dos demais tratamentos, superando-as nas características de crescimento analisadas, o que se manteve até os 49 meses após o plantio (Tabela 6).

Aos 33 e 49 meses após o plantio, pode-se verificar que as plantas de eucalipto da região de Três Lagoas, MS, que cresceram nas parcelas do tratamento de faixa crescente de controle que iniciaram com $50 \mathrm{~cm}$ (T9 e T10) ou das faixas crescentes que iniciaram com $100 \mathrm{~cm}$ (T11) e $125 \mathrm{~cm}$ (T13) - contraste $\mathrm{Y}(10)$ - apresentaram tendência de maior volume e I.M.A. de madeira (Tabelas $5 \mathrm{e}$ $6)$. 
Tabela 3. Efeito das faixas de controle do capim-braquiária sobre a variação relativa (\%) em relação àtestemunha "no limpo" em D.A.P., altura, volume e I.M.A. de madeira das plantas de eucalipto. Três Lagoas, M.S.

\begin{tabular}{|c|c|c|c|c|c|c|c|c|c|c|c|c|}
\hline \multicolumn{13}{|c|}{ ALTURA (m) } \\
\hline MESES & $T 1$ & $\% R$ & T3 & $\% R$ & T4 & $\% R$ & $T 6$ & $\% R$ & $T 7$ & $\% R$ & T9 & $\% R$ \\
\hline 17 & 3,69 & $-51,13$ & 4,38 & $-41,99$ & 6,95 & $-7,95$ & 7,55 & 100 & 7,05 & $-6,62$ & 6,51 & $-13,77$ \\
\hline 22 & 5,91 & $-45,02$ & 6,99 & $-34,98$ & 10,52 & $-2,14$ & 10,75 & 100 & 10,73 & $-0,19$ & 10,53 & $-2,05$ \\
\hline 33 & 13,02 & $-21,38$ & 14,41 & $-12,98$ & 16,80 & 1,45 & 16,56 & 100 & 16,67 & 1,00 & 16,91 & 2,11 \\
\hline 49 & 15,36 & $-20,78$ & 17,44 & $-10,06$ & 19,33 & 0,31 & 19,39 & 100 & 19,37 & $-0,10$ & 19,55 & 0,83 \\
\hline \multicolumn{13}{|c|}{ D.A.P. (cm) } \\
\hline 22 & 4,58 & $-49,34$ & 5,63 & $-37,72$ & 8,62 & $-4,65$ & 9,04 & 100 & 8,20 & $-9,29$ & 8,32 & - 7,96 \\
\hline 33 & 7,53 & $-28,42$ & 9,43 & $-10,36$ & 10,82 & 2,85 & 10,52 & 100 & 10,69 & 1,62 & 10,84 & 3,04 \\
\hline 49 & 8,85 & $-27,46$ & 11,10 & $-9,02$ & 12,04 & $-1,31$ & 12,20 & 100 & 12,02 & $-1,48$ & 12,45 & 2,05 \\
\hline \multicolumn{13}{|c|}{ VOLUME DE MADEIRA $\left(\mathrm{m}^{3} \cdot h \mathrm{a}^{-1}\right)$} \\
\hline 33 & $32,79^{1}$ & $-51,42$ & 57,69 & $-14,52$ & 74,96 & 11,07 & 67,49 & 100 & 77,92 & 15,45 & 75,81 & 12,33 \\
\hline 49 & 52,63 & $-50,79$ & 94,61 & $-11,54$ & 110,23 & 3,07 & 106,95 & 100 & 118,15 & 10,47 & 118,77 & 11,05 \\
\hline \multicolumn{13}{|c|}{ I.M.A. $\left(m^{3} \cdot h a^{-1} \cdot a n o^{-1}\right)$} \\
\hline 33 & $11,92^{1}$ & $-51,43$ & 20,98 & $-14,51$ & 27,26 & 11,08 & 24,54 & 100 & 28,34 & 15,48 & 27,57 & 12,35 \\
\hline 49 & 12,89 & $-50,78$ & 23,17 & $-11,53$ & 27,00 & 3,09 & 26,19 & 100 & 28,93 & 10,46 & 29,09 & 11,07 \\
\hline
\end{tabular}

${ }^{1}$ Valores médios de altura, D.A.P., volume de madeira e I.M.A.; 2 Variação relativa (\%) em relação àtestemunha no limpo (tratamento 6) 
Tabela 4. Efeito das faixas de controle das plantas daninhas sobre a porcentagem de redução média em altura, D.A.P., volume e I.M.A. de madeira das plantas de eucalipto. Brotas, SP.

\begin{tabular}{|c|c|c|c|c|c|c|c|c|c|c|c|c|}
\hline \multicolumn{13}{|c|}{$\operatorname{ALTURA}(\mathrm{m})$} \\
\hline MESES & $T 1$ & $\% R$ & T3 & $\% R$ & T4 & $\% R$ & T6 & $\% R$ & $T 7$ & $\% R$ & T9 & $\% R$ \\
\hline 13 & 6,56 & $-27,11$ & 6,96 & $-22,67$ & 8,50 & $-5,56$ & 9,00 & 100 & 9,05 & $+0,56$ & 9,30 & 3,33 \\
\hline 24 & 9,79 & $-4,49$ & 9,32 & $-9,07$ & 10,49 & 2,34 & 10,25 & 100 & 10,14 & $-1,07$ & 10,79 & 5,27 \\
\hline 37 & 14,68 & $-2,33$ & 14,19 & $-5,59$ & 15,52 & 3,26 & 15,03 & 100 & 14,78 & $-1,66$ & 15,49 & 3,06 \\
\hline 49 & 18,41 & $+0,99$ & 17,69 & $-2,96$ & 18,97 & 4,06 & 18,23 & 100 & 17,55 & $-3,73$ & 18,71 & 2,63 \\
\hline \multicolumn{13}{|c|}{ D.A.P.(cm) } \\
\hline 13 & $5,19^{1}$ & $-21,36$ & 5,08 & $-23,03$ & 6,08 & $-7,88$ & 6,60 & 100 & 6,56 & $-0,61$ & 5,81 & $-11,97$ \\
\hline 24 & 8,71 & $-1,14$ & 8,18 & $-7,15$ & 9,50 & 7,83 & 8,81 & 100 & 8,91 & 1,14 & 9,34 & 6,02 \\
\hline 37 & 11,35 & 8,82 & 10,36 & $-0,67$ & 11,77 & 12,85 & 10,43 & 100 & 10,48 & 0,47 & 11,31 & 8,44 \\
\hline 49 & 13,09 & 10,75 & 11,82 & 0,00 & 13,23 & 11,93 & 11,82 & 100 & 12,20 & 3,21 & 12,63 & 6,85 \\
\hline \multicolumn{13}{|c|}{ VOLUME DE MADEIRA . $\left(\mathrm{m}^{3} \cdot h \mathrm{a}^{-1}\right)$} \\
\hline 24 & 31,19 & $-4,73$ & 26,42 & $-19,30$ & 40,49 & 23,67 & 32,74 & 100 & 36,36 & 11,06 & 36,69 & 12,07 \\
\hline 37 & 79,41 & 13,39 & 65,35 & $-6,68$ & 94,95 & 35,58 & 70,03 & 100 & 76,75 & 9,60 & 79,72 & 13,84 \\
\hline 49 & 134,20 & 19,34 & 106,72 & $-5,10$ & 148,17 & 31,77 & 112,45 & 100 & 122,58 & 9,01 & 121,33 & 7,90 \\
\hline \multicolumn{13}{|c|}{ I.M.A. . $\left(m^{3} \cdot h a^{-1} \cdot a n o^{-1}\right)$} \\
\hline 24 & 15,60 & $-4,70$ & 13,21 & $-19,30$ & 20,25 & 23,70 & 16,37 & 100 & 18,18 & 11,06 & 18,35 & 12,09 \\
\hline 37 & 25,76 & 13,43 & 21,20 & $-6,65$ & 30,79 & 35,58 & 22,71 & 100 & 24,89 & 9,60 & 25,86 & 13,87 \\
\hline 49 & 32,86 & 19,32 & 26,14 & $-5,08$ & 36,29 & 31,77 & 27,54 & 100 & 30,02 & 9,01 & 29,71 & 7,88 \\
\hline
\end{tabular}

${ }^{1}$. Valores médios $(\mathrm{cm}){ }^{2}$ Porcentagem de redução calculada em relação ao tratamento 6 , ou seja, testemunha no limpo' 
Tabela 5. Valores de $\mathrm{F}$ dos contrastes de interesse em relação à altura e o D.A.P. das plantas de eucalipto. Três Lagoas, MS. e Brotas, SP.

\begin{tabular}{|c|c|c|c|c|c|c|c|c|c|c|c|c|c|c|c|}
\hline \multirow{4}{*}{ CONT } & \multicolumn{15}{|c|}{ MESES APÓS O PLANTIO } \\
\hline & \multicolumn{7}{|c|}{ TRÊS LAGOAS, MS. } & \multicolumn{8}{|c|}{ BROTAS, SP. } \\
\hline & \multirow[b]{2}{*}{17} & \multicolumn{2}{|c|}{ ALTURA (M) } & \multicolumn{4}{|c|}{$\operatorname{DAP}(\mathrm{cm})$} & \multicolumn{3}{|c|}{$\operatorname{ALTURA}(m)$} & \multicolumn{5}{|c|}{$D A P(\mathrm{~cm})$} \\
\hline & & 22 & 33 & 49 & 22 & 33 & 49 & 13 & 24 & 37 & 49 & 13 & 24 & 37 & 49 \\
\hline \multirow[t]{2}{*}{$Y(1)$} & $146,98^{*}$ & $149,30^{*}$ & $92,70^{* *}$ & $44,70^{\star *}$ & $114,92^{*}$ & $61,65^{* *}$ & $28,08^{* *}$ & $42,09^{\star *}$ & $11,49^{\star *}$ & $10,42^{* *}$ & $1,80 \mathrm{NS}$ & $16,81^{* *}$ & $8,36^{* *}$ & $1,12 \mathrm{NS}$ & $0,07 \mathrm{NS}$ \\
\hline & * & * & & & * & & & & & & & & & & \\
\hline$Y(2)$ & 5,08 * & $3,30 \mathrm{NS}$ & 5,24 * & $10,17^{\star *}$ & $1,57 \mathrm{NS}$ & 29,53 ** & $11,64^{\star *}$ & $0,49 \mathrm{NS}$ & $1,30 \mathrm{NS}$ & $1,37 \mathrm{NS}$ & $1,77 \mathrm{NS}$ & $0,04 \mathrm{NS}$ & $1,56 \mathrm{NS}$ & $1,36 \mathrm{NS}$ & $2,02 \mathrm{NS}$ \\
\hline$Y(3)$ & 25,72 ** & 35,09 ** & 22,79 ** & 5,53 * & $22,10^{* *}$ & $2,79 \mathrm{NS}$ & $0,97 \mathrm{NS}$ & $7,42^{* *}$ & $7,91 * *$ & $8,05^{*}$ & $4,69^{*}$ & $3,05 \mathrm{NS}$ & $8,73^{* *}$ & $4,15^{*}$ & $2,49 \mathrm{NS}$ \\
\hline$Y(4)$ & $0,48 \mathrm{NS}$ & $0,16 \mathrm{NS}$ & $0,19 \mathrm{NS}$ & $0,01 \mathrm{NS}$ & $1,18 \mathrm{NS}$ & $0,39 \mathrm{NS}$ & $0,01 \mathrm{NS}$ & $0,77 \mathrm{NS}$ & $0,45 \mathrm{NS}$ & $1,07 \mathrm{NS}$ & $1,51 \mathrm{NS}$ & 0,86 NS & $2,32 \mathrm{NS}$ & $5,08^{*}$ & $2,49 \mathrm{NS}$ \\
\hline$Y(5)$ & 18,22 ** & 39,60 ** & $20,67^{* *}$ & 5,81 * & $23,81^{* *}$ & $2,20 \mathrm{NS}$ & $0,91 \mathrm{NS}$ & $13,65^{* *}$ & $3,62 \mathrm{NS}$ & $3,46 \mathrm{NS}$ & $0,06 \mathrm{NS}$ & $6,77^{*}$ & $2,56 \mathrm{NS}$ & $0,12 \mathrm{NS}$ & $0,77 \mathrm{NS}$ \\
\hline$Y(6)$ & $11,47^{* *}$ & $3,15 \mathrm{NS}$ & 4,26 * & $1,79 \mathrm{NS}$ & $11,43^{* *}$ & $0,08 \mathrm{NS}$ & $1,25 \mathrm{NS}$ & $0,01 \mathrm{NS}$ & $1,19 \mathrm{NS}$ & $2,09 \mathrm{NS}$ & $0,56 \mathrm{NS}$ & $0,01 \mathrm{NS}$ & $0,01 \mathrm{NS}$ & $1,43 \mathrm{NS}$ & 0,02 NS \\
\hline$Y(7)$ & 0,64 NS & $0,14 \mathrm{MS}$ & $0,05 \mathrm{NS}$ & $0,01 \mathrm{NS}$ & $0,03 \mathrm{NS}$ & $0,04 \mathrm{NS}$ & $0,01 \mathrm{NS}$ & $0,94 \mathrm{NS}$ & $0,83 \mathrm{NS}$ & $0,96 \mathrm{NS}$ & $5,78^{*}$ & 0,73 NS & $1,83 \mathrm{NS}$ & $2,86 \mathrm{NS}$ & $0,49 \mathrm{NS}$ \\
\hline$Y(8)$ & 20,54 ** & 29,19 ** & 24,80 ** & 4,23 * & 15,19 ** & 2,89 NS & $0,87 \mathrm{NS}$ & $17,03^{* *}$ & $6,18^{*}$ & $5,77^{*}$ & $3,10 \mathrm{NS}$ & $1,65 \mathrm{NS}$ & 5,64 * & $2,15 \mathrm{NS}$ & $0,80 \mathrm{NS}$ \\
\hline$Y(9)$ & $0,15 \mathrm{NS}$ & $0,34 \mathrm{NS}$ & $0,01 \mathrm{NS}$ & $0,33 \mathrm{NS}$ & $0,01 \mathrm{NS}$ & $0,68 \mathrm{NS}$ & $0,38 \mathrm{NS}$ & $0,46 \mathrm{NS}$ & $0,41 \mathrm{NS}$ & $0,21 \mathrm{NS}$ & $0,26 \mathrm{NS}$ & 0,23 NS & $0,32 \mathrm{NS}$ & $0,39 \mathrm{NS}$ & $0,02 \mathrm{NS}$ \\
\hline$Y(10)$ & 0,29 NS & $0,27 \mathrm{NS}$ & 0,04 NS & $0,09 \mathrm{NS}$ & $0,65 \mathrm{NS}$ & $0,01 \mathrm{NS}$ & $0,01 \mathrm{NS}$ & $1,97 \mathrm{NS}$ & $0,11 \mathrm{NS}$ & $0,19 \mathrm{NS}$ & $0,17 \mathrm{NS}$ & $0,21 \mathrm{NS}$ & $0,34 \mathrm{NS}$ & $0,33 \mathrm{NS}$ & $0,47 \mathrm{NS}$ \\
\hline
\end{tabular}

ns: não significativo pelo Teste $\mathrm{F} ;{ }^{*}$ significativo pelo Teste $\mathrm{F}$ a de $5 \%$ de probabilidade; ${ }^{\star *}$ significativo pelo Teste $\mathrm{F}$ a de $1 \%$ de probabilidade. 
As plantas de eucalipto das duas regiões que cresceram nas parcelas nas quais as plantas daninhas foram controladas com faixas fixas de $100 \mathrm{~cm}$ ou com faixas crescentes que iniciaram com $50 \mathrm{~cm}$ (T4 e T9) apresentaram valores semelhantes de altura e D.A.P. até os 49 meses após o plantio (Contraste $Y(10)$ Tabela 3).

Aos 24, 37 e 49 meses após o plantio em Brotas, SP, pode-se observar que as faixas fixas de controle iguais ou superiores a $100 \mathrm{~cm}$ e as faixas crescentes promoveram maior D.A.P., altura, volume e I.M.A. de madeira, quando comparadas com a testemunha não capinada ("no mato") e as faixas constantes de controle de 25 e $50 \mathrm{~cm}$ (Tabelas 5 e 7).

Pelo contraste $Y(10)$, foi observado que as plantas de eucalipto que cresceram nas parcelas com faixa crescente de $50 \mathrm{~cm}$ (T9 e T10) não apresentaram diferença significativa em D.A.P. e altura no período dos 13 aos 49 meses após o plantio na região de Três Lagoas, MS, e dos 17 aos 49 meses em Brotas, SP, quando comparadas com as plantas do tratamento de faixa fixa de 100 cm (T4) (Tabela 5). No entanto, quando se analisa a estimativa de produção podese observar a tendência de maiores valores de volume e I.M.A. de madeira nas plantas de eucalipto da faixa crescente de $50 \mathrm{~cm}$ (Tabela 6).

\subsection{Conclusões}

Pode-se afirmar que:

A faixa fixa de controle de $50 \mathrm{~cm}$ de cada lado da linha de plantio não foi suficiente para manter as plantas de eucalipto livres da interferência das plantas daninhas. As faixas de controle recomendadas no manejo integrado de plantas daninhas no primeiro ano de desenvolvimento da cultura foram æ̀ faixas fixas iguais a $100 \mathrm{~cm}$ e as crescentes superiores a $50 \mathrm{~cm}$. 
Tabela 6. Efeito das faixas de controle do capim-braquiária sobre a altura, o D.A.P., volume e I.M.A. médio de madeira de plantas de eucalipto. Três Lagoas, MS.

\begin{tabular}{|c|c|c|c|c|c|c|c|c|c|c|c|}
\hline \multicolumn{12}{|c|}{ Meses após o plantio } \\
\hline \multirow[b]{2}{*}{ Trat } & \multicolumn{4}{|c|}{ Altura (m) } & \multicolumn{3}{|c|}{ D.A.P. $(\mathrm{cm})$} & \multicolumn{2}{|c|}{ Volume $\left(\mathrm{m}^{3} \cdot h \mathrm{~h}^{-1}\right)$} & \multicolumn{2}{|c|}{ I.M.A. $\left(m^{3} h a^{-1} a^{-1}\right)$} \\
\hline & 17 & 22 & 33 & 49 & 22 & 33 & 49 & 33 & 49 & 33 & 49 \\
\hline $\mathrm{T} 1$ & $3,69 b^{1}$ & $5,91 \mathrm{~b}$ & $13,02 \mathrm{c}$ & $15,36 \mathrm{~d}$ & $4,58 \mathrm{~b}$ & $7,53 \mathrm{c}$ & $8,85 \mathrm{c}$ & $32,79 \mathrm{c}$ & $59,65 \mathrm{c}$ & $11,92 \mathrm{c}$ & $12,89 \mathrm{c}$ \\
\hline $\mathrm{T} 2$ & $3,61 \mathrm{~b}$ & $5,95 b$ & $13,69 \mathrm{c}$ & $17,05 \mathrm{~cd}$ & $4,61 \mathrm{~b}$ & $8,42 \mathrm{bc}$ & $10,07 \mathrm{bc}$ & $35,47 \mathrm{bc}$ & $59,74 \mathrm{bc}$ & $12,90 \mathrm{bc}$ & $14,63 \mathrm{bc}$ \\
\hline T3 & $4,38 \mathrm{~b}$ & $6,99 \mathrm{~b}$ & $14,41 \mathrm{bc}$ & $17,44 \mathrm{bcd}$ & $5,63 \mathrm{~b}$ & $9,43 a b c$ & $11,10 a b c$ & $57,69 \mathrm{abc}$ & $94,61 \mathrm{abc}$ & $20,98 a b c$ & $23,17 \mathrm{abc}$ \\
\hline $\mathrm{T} 4$ & $6,95 \mathrm{a}$ & $10,52 \mathrm{a}$ & $16,80 \mathrm{a}$ & $19,33 a b c$ & $8,62 \mathrm{a}$ & $10,82 a b$ & $12,04 a b$ & $74,96 a b c$ & $110,23 a b c$ & $27,26 a b c$ & $27,00 a b c$ \\
\hline T5 & $7,35 a$ & 10,66 a & $16,69 a b$ & $19,53 a b$ & $8,70 \mathrm{a}$ & $11,11 \mathrm{a}$ & $12,66 \mathrm{ab}$ & $74,45 a b c$ & $122,62 \mathrm{ab}$ & $28,89 a b c$ & $30,03 \mathrm{a}$ \\
\hline T6 & $7,55 \mathrm{a}$ & $10,75 a$ & $16,56 \mathrm{ab}$ & $19,39 a b c$ & $9,04 \mathrm{a}$ & $10,52 \mathrm{ab}$ & $12,20 a b$ & $67,49 a b c$ & $106,95 \mathrm{abc}$ & $24,54 a b c$ & $26,19 a b c$ \\
\hline $\mathrm{T} 7$ & $7,05 \mathrm{a}$ & $10,73 \mathrm{a}$ & $16,67 \mathrm{ab}$ & $19,37 \mathrm{abc}$ & $8,20 \mathrm{a}$ & $10,69 a b$ & $12,02 a b$ & $77,92 \mathrm{ab}$ & $118,15 a b c$ & $28,34 a b$ & $28,93 a b c$ \\
\hline T8 & $6,88 a$ & $10,36 \mathrm{a}$ & $16,35 \mathrm{ab}$ & $19,20 a b c$ & 7,98 a & $10,78 \mathrm{ab}$ & $12,05 a b$ & $76,02 \mathrm{abc}$ & $114,62 \mathrm{abc}$ & $27,64 \mathrm{abc}$ & $28,07 \mathrm{abc}$ \\
\hline T9 & $6,51 \mathrm{a}$ & $10,53 \mathrm{a}$ & $16,91 \mathrm{a}$ & $19,55 a b$ & $8,32 \mathrm{a}$ & $10,84 a b$ & $12,45 a b$ & $75,81 \mathrm{abc}$ & $118,77 \mathrm{abc}$ & $27,57 \mathrm{abc}$ & $29,09 a b c$ \\
\hline $\mathrm{T} 10$ & $6,65 a$ & $10,33 a$ & $16,25 \mathrm{ab}$ & $19,62 a b$ & $8,13 a$ & $11,19 a$ & $12,93 \mathrm{a}$ & $81,02 \mathrm{a}$ & $128,41 \mathrm{a}$ & 29,46 a & $31,45 \mathrm{a}$ \\
\hline $\mathrm{T} 11$ & 7,73 a & $11,34 \mathrm{a}$ & $17,28 a$ & $19,89 a$ & 9,16 a & $10,99 a$ & $12,61 \mathrm{ab}$ & $80,18 \mathrm{ab}$ & $123,92 a b$ & $29,16 \mathrm{ab}$ & $30,35 \mathrm{ab}$ \\
\hline $\mathrm{T} 12$ & $7,36 \mathrm{a}$ & $10,84 a$ & $17,41 \mathrm{a}$ & $19,99 \mathrm{a}$ & $9,15 \mathrm{a}$ & $11,22 \mathrm{a}$ & $12,92 \mathrm{a}$ & $81,51 \mathrm{a}$ & $128,48 \mathrm{a}$ & 29,64 a & $31,46 \mathrm{a}$ \\
\hline $\mathrm{T} 13$ & $7,72 \mathrm{a}$ & $10,97 \mathrm{a}$ & $17,34 \mathrm{a}$ & $20,19 a$ & $9,38 a$ & $11,39 a$ & $12,95 \mathrm{a}$ & 90,26 a & $140,13 \mathrm{a}$ & $32,82 \mathrm{a}$ & $34,32 \mathrm{a}$ \\
\hline $\mathrm{F}$ & $18,49^{\star \star}$ & $20,60^{\star *}$ & $14,61^{\star *}$ & $8,71^{\star \star}$ & $17,63^{* *}$ & $5,88^{* *}$ & $5,01^{* *}$ & $3,87^{\star}$ & 3,60 * & $3,87^{*}$ & $3,60^{*}$ \\
\hline DMS. & 1,74 & 0,92 & 2,3023 & 2,3885 & 0,20 & 2,4338 & 2,7275 & 44,7810 & 68,5070 & 44,7810 & 68,5070 \\
\hline CV\% & 10,84 & 8,97 & 4,80 & 5,07 & 10,41 & 9,41 & 9,19 & 25,65 & 25,18 & 25,65 & 25,18 \\
\hline
\end{tabular}

1.Médias seguidas de mesma letra não diferem significativamente entre si pelo Teste de Tukey a de 1 \% de probabilidade; * Significativo pelo Teste F a $5 \%$ de probabilidade; ** Significativo pelo Teste $\mathrm{F}$ a de $1 \%$ de probabilidade. 
Tabela 7. Efeito das faixas de controle das plantas daninhas sobre a altura, o D.A.P., volume e I.M.A. de madeira de plantas de eucalipto. Brotas, SP.

\begin{tabular}{|c|c|c|c|c|c|c|c|c|c|c|c|c|c|c|}
\hline \multicolumn{15}{|c|}{ Meses após o plantio } \\
\hline \multirow[b]{2}{*}{$\mathrm{T}$} & \multicolumn{4}{|c|}{ Altura $(m)$} & \multicolumn{4}{|c|}{ D.A.P. (cm) } & \multicolumn{3}{|c|}{ Volume $\left(\mathrm{m}^{3} \cdot h \mathrm{~h}^{-1}\right)$} & \multicolumn{3}{|c|}{ I.M.A. $\quad\left(m^{3} h a^{-1} a^{-1}\right)$} \\
\hline & 13 & 24 & 39 & 47 & 13 & 24 & 39 & 47 & 24 & 39 & 47 & 24 & 39 & 47 \\
\hline T2 & $6,45 d$ & $9,53 \mathrm{a}$ & $3 a$ & , & 39 a & $6 a$ & $8 \mathrm{a}$ & $26 \mathrm{a}$ & $94 \mathrm{a}$ & 65,44 & $109,97 a$ & $2,47 \mathrm{a}$ & $21,22 \mathrm{a}$ & $26,93 \mathrm{a}$ \\
\hline T3 & $6,96 \mathrm{bcd}$ & $9,32 \mathrm{a}$ & $14,19 \mathrm{a}$ & $17,69^{\mathrm{a}}$ & $5,08 \mathrm{a}$ & $8,18 \mathrm{a}$ & $10,36 \mathrm{a}$ & $11,82 \mathrm{a}$ & $26,42 \mathrm{a}$ & $65,35 \mathrm{a}$ & $106,72 a$ & $13,21 \mathrm{a}$ & $21,20 \mathrm{a}$ & $26,14 \mathrm{a}$ \\
\hline T6 & $9,00 \mathrm{a}$ & $10,25 \mathrm{a}$ & $15,03 \mathrm{a}$ & $18,23^{\mathrm{a}}$ & $6,60 \mathrm{a}$ & $8,81 \mathrm{a}$ & $10,43 a$ & $11,82 \mathrm{a}$ & $32,74 a$ & $70,03 \mathrm{a}$ & $112,45 a$ & $16,37 \mathrm{a}$ & 22,71 a & $27,54 \mathrm{a}$ \\
\hline$T 7$ & $9,05 \mathrm{a}$ & 10 & 14 & $17,55^{\mathrm{a}}$ & 0 & $8,91 \mathrm{a}$ & 10 & 12 & $36,36 \mathrm{a}$ & $76,75 \mathrm{a}$ & $122,58 a$ & $18,18 \mathrm{a}$ & $24,89 a$ & $30,02 \mathrm{a}$ \\
\hline T8 & $8,94 a b$ & $10,66 \mathrm{a}$ & $15,15 \mathrm{a}$ & $18,67^{a}$ & $6,45 a$ & $9,70 \mathrm{a}$ & $11,61 \mathrm{a}$ & $13,28 \mathrm{a}$ & 40,49 a & $85,10 \mathrm{a}$ & $137,69 a$ & $20,25 \mathrm{a}$ & $27,60 \mathrm{a}$ & $33,72 \mathrm{a}$ \\
\hline T9 & $9,30 \mathrm{a}$ & $10,79 a$ & $15,49 \mathrm{a}$ & $18,71^{\mathrm{a}}$ & $5,81 \mathrm{a}$ & $9,34 \mathrm{a}$ & $11,31 \mathrm{a}$ & $12,63 \mathrm{a}$ & 36,69 a & 79,72 a & $121,33 a$ & $18,35 \mathrm{a}$ & 25,86 a & $2971 \mathrm{a}$ \\
\hline T13 & $9,25 a$ & $10,79 a$ & $15,25 \mathrm{a}$ & $18,64 a$ & $6,58 \mathrm{a}$ & $9,42 \mathrm{a}$ & $11,37 \mathrm{a}$ & $12,89 \mathrm{a}$ & $33,77 \mathrm{a}$ & $73,51 \mathrm{a}$ & $114,60 \mathrm{a}$ & $16,89 a$ & $19,58 \mathrm{a}$ & $28,06 \mathrm{a}$ \\
\hline $\mathrm{F}$ & 6,94 & 2,2 & $S$ & $0,97 \mathrm{NS}$ & 31 & VS & 0,8 & $0,70 \mathrm{NS}$ & NS & 1,03 & 1,15 & $1,43 \mathrm{NS}$ & IS & JS \\
\hline DMS & 2,0103 & 1,6164 & 1,7964 & 2,028 & 1,7887 & 2,1402 & 2,5491 & 2,8845 & 20,892 & 45,065 & 65,308 & 20,892 & 45,065 & 65,308 \\
\hline CV\% & 9,48 & 6,30 & 4,81 & 4,43 & 11,75 & 9,48 & 9,22 & 9,17 & 24,82 & 23,93 & 21,67 & 24,82 & 23,93 & 21,67 \\
\hline
\end{tabular}

\footnotetext{
${ }^{1}$ Médias seguidas de mesma letra não diferem significativamente entre si pelo Teste de Tukey a de $1 \%$ de probabilidade; * Significativo pelo Teste $\mathrm{F}$ a $5 \%$ de probabilidade; ** Significativo pelo Teste $\mathrm{F}$ a de $1 \%$ de probabilidade
} 


\section{PERÍODOS DE CONTROLE DE PLANTAS DANINHAS E SEUS REFLEXOS No CRESCIMENTO DO EUCALIPTO}

\section{Resumo}

Com objetivo estudar os efeitos dos períodos de controle das plantas daninhas sobre o crescimento de Eucalyptus grandis W. Hill ex Maiden x $E$. urophylla S. T. Blake foram conduzidos dois ensaios localizados nos municípios de Três Lagoas, MS, e Brotas, SP, no período de janeiro de 1997 a março de 2001 e de fevereiro de 1997 a fevereiro de 2001. Os tratamentos consistiram de diferentes períodos de convivência e de controle das plantas daninhas na cultura divididos em dois grupos. No primeiro, a convivência iniciava no plantio e era estendida até 28 , 56, 84, 112, 140, 168, 252 e 364 dias. No segundo, a convivência iniciava aos 0 , 28, 56, 84, 112, 140, 168 e 252 dias e era estendida até os 364 dias. As populações mais freqüentes que ocorreram nas áreas experimentais foram Brachiaria decumbens, Spermacoce latifolia, Cyperus rotundus e algumas plantas típicas de cerrado. Para Três Lagoas, MS, o período total de prevenção à interferência (PTPI) foi de 180 e 210 dias, quando se considera a redução de 5 e $2 \%$ no volume de madeira aos 50 meses após o plantio, respectivamente. No entanto, para Brotas, SP, o PTPI foi de 60 dias, considerando-se $5 \%$ de redução em volume de madeira aos 24 meses após o plantio, período no qual a interferência foi significativa. Todavia, pode-se questionar o efeito da interferência 
das plantas daninhas distribuídas irregularmente na área de Brotas, SP e sugerir a hipótese de recuperação das plantas de eucalipto a partir de 48 meses, bem como o potencial alelopático dos restos culturais do eucalipto.

PALAVRAS CHAVE: Brachiaria decumbens, eucalipto, manejo de plantas daninhas, competição e alelopatia.

\section{THE WEED CONTROL PERIODS AND ITS EFFECTS AT THE EUCALYPTUS GROWTH}

\section{Summary}

This research has been carried out in Três Lagoas, Mato Grosso do Sul State and in Brotas, São Paulo State, Brazil, from January 1997 through March 2001 and from February 1997 through 2001 with the purpose of studying of the weed interference at Eucalyptus grandis W. Hill Ex Maiden x Eucalyptus urophylla S. T. Blake growth. The experimental design has been completed taking some blocks at random in four reaplications. The treatments have consisted of different extensions and time limits of the weed control periods. The weed control periods have been divided in two groups. At the first one, the weed control periods have been since the Eucalyptus plantation to 28, 56, 112, 140, 168, 224, 252 and 364 days. At the second group the weed control periods has begun at $0,28,56,112$, 140, 168, 224 and 252 days after the plantation and has finished at the end of the 364 days. The main weeds were Brachiaria decumbens, Spermacoce latifola, Cyperus rotundus and the same typical savannah plants. To assure the crop productivity in Três Lagoas it was necessary to keep a weed control period in a range of 180 and 210 days after the plantation (PTPI), in that case it should consider reduction of $5 \%$ at the wood volume in the 50 months after the plantation. However, in Brotas area it was necessary to keep the weed control plantation in a range of 60 days to consider the wood volume throughout 24 months after the plantation. 
However, it might ask about question the effects of the weed interference in a case of a low density and in a weed irregular distribution in that area suggesting the improvement at the quality of the Eucalyptus plants in a range of 48 months after the plantation the allelophatic potential from the Eucalyptus mulching as well.

KEY WORDS: Brachiaria decumbens, Eucalyptus, weed management, competition and allelopathy.

\subsection{Introdução}

Os recursos naturais têm sido, desde o descobrimento do país, os principais e mais tradicionais componentes da riqueza nacional. De forma incontestável, entre eles, ocupa posição de destaque o nosso patrimônio florestal, o qual requer enorme responsabilidade no sentido de ser bem manejado e preservado, de forma a atender as atuais demandas sociais, econômicas e ambientais a ele vinculadas (Brito, 2000).

A produtividade das plantações florestais brasileiras está aquém de seu potencial, havendo amplas possibilidades de elevá-la, adotando-se práticas corretas de manejo florestal. O grande desafio consiste em identificar o equilíbrio entre as estratégias e métodos silviculturais que elevem a produtividade em longo prazo, minimizando os impactos ambientais (Gonçalves et al., 2000).

A ocorrência de um determinado problema operacional e o desenvolvimento de pesquisa com a geração de resultados visando solucionar ou minimizar tal dificuldade, são os primeiros passos para a evolução técnica de atividades silviculturais (Benedetti, 2000).

As culturas florestais estão sujeitas a uma série de fatores ecológicos que, direta ou indiretamente, podem afetar o crescimento das árvores e a produção de madeira, carvão e celulose. A interferência imposta pela presença das plantas daninhas nessas áreas é um dos pontos mais críticos na implantação do eucalipto. Essas plantas podem competir pelos recursos limitantes do meio (principalmente 
água, luz e nutrientes), liberar substâncias alelopáticas e assim inibir o desenvolvimento inicial do eucalipto, hospedar pragas e doenças comuns àcultura, propagar incêndios ou ainda interferir no rendimento da colheita da madeira, elevando assim os custos de produção (Pitelli \& Marchi, 1991; Alves et al., 1999 e Toledo, 1999).

O manejo das plantas daninhas em áreas florestais, nas diversas etapas do seu processo produtivo, por meio do controle de faixas (Toledo, 1998 e Silva, 1999) ou pela manutenção destas plantas em períodos de ausência de competição com a cultura (Pitelli et al., 1991; Marchi, 1996 e Toledo et al. 2000), é realizado, basicamente, pelo emprego de métodos mecânicos e químicos, isolados ou combinados (Toledo, 1999). Para que este manejo seja eficaz, se faz necessário determinar o período em que as plantas de eucalipto devem ser mantidas sem a presença das plantas daninhas, de modo a assegurar pleno potencial de crescimento e de produção da cultura (PTPI) (Pitelli \& Durigan, 1984).

A pesquisa teve por objetivo estudar os efeitos dos períodos de controle das plantas daninhas sobre o crescimento de Eucalyptus grandis W. Hill ex Maiden x Eucalyptus urophylla S.T. Blake nos municípios de Três Lagoas, MS e Brotas, SP.

\subsection{Material e Métodos}

A pesquisa foi conduzida em duas áreas florestais pertencentes a International Paper do Brasil Ltda., localizadas nos municípios de Três Lagoas, MS e de Brotas, SP, no período de janeiro de 1997 a março de 2001 e fevereiro de 1997 a fevereiro de 2001.

As áreas experimentais foram selecionadas quanto à uniformidade na infestação de plantas daninhas, sendo esta representativa das áreas de produção da empresa florestal. A área localizada em Três Lagoas, MS era anteriormente cultivada com pastagem de capim-braquiária (Brachiaria decumbens Stapf), 
enquanto a de Brotas, SP era área de reforma de eucalipto. Em levantamento prévio, pela técnica de amostragens aleatórias, foi constatado que as populações mais freqüentes foram o capim-braquiária, a erva-quente (Spermacoce latifolia Aubl.), a tiririca (Cyperus rotundus L.) e algumas rebrotas de cerrado, enquanto em Brotas, SP, além destas o capim-amargoso (Rhynchelytrum repens (Willd.) Hubbart), o capim-amargoso (Digitaria insularis (L.) Mez ex Ekman), o capimgordura (Melinis minutiflora Beauv.), a malva-vermelha (Croton glandulosus L.) e o cipó-de-São-João (Pyrestegia venusta Miers), eram distribuídas em reboleiras nesta área em função da presença de cobertura morta e restos culturais do eucalipto.

$\mathrm{Na}$ área de Três Lagoas, MS, foi efetuada inicialmente a derrubada de árvores esparsas e a passagem de uma gradagem com máquina pesada e de uma gradagem média em área total. Em seguida, foram realizadas a abertura dos sulcos e a adubação de plantio, a qual constituiu na distribuição, ao longo do sulco, de $140 \mathrm{~kg} \cdot \mathrm{ha}^{-1}$ do adubo N-P-K na fórmula 08-32-16 + micronutrientes $(0,5 \% \mathrm{~B}$; $0,07 \%$ Cu e 0,3 \% de Zn). Esse experimento foi conduzido em Latossolo Vermelho - Escuro, textura média e álico.

$\mathrm{Na}$ área de Brotas, SP, inicialmente foi efetuado o controle químico das plantas daninhas pela aplicação de $1,08 \mathrm{~kg}$ e.a.ha ${ }^{-1}$ de glyphosate em área total, utilizando um pulverizador tratorizado, munido de bicos tipo espuma, regulado para um consumo de calda de 300 L.ha $^{-1}$. Em seguida, foi realizado o preparo da área em faixas de plantio com subsolador e posterior abertura dos sulcos, calagem (1 tonelada de calcário dolomítico.ha ${ }^{-1}$ ) e a adubação de plantio, que constituiu na distribuição, ao longo do sulco, de $120 \mathrm{~kg} \cdot \mathrm{ha}^{-1}$ do adubo N-P-K na fórmula 10-3010.

Aos 4 e 8 meses após o plantio da área de Brotas, SP foram realizadas as adubações de cobertura, que constituíram na distribuição, ao longo do sulco, de $120 \mathrm{~kg} \cdot \mathrm{ha}^{-1}$ do adubo N-P-K nas fórmulas 10-30-10 e 14-00-28, respectivamente. 
As mudas de eucalipto foram provenientes de microprogação. O clone utilizado é um híbrido resultante do cruzamento entre Eucalyptus grandis W. Hill ex Maiden x Eucalyptus urophylla S.T.Blake, que apresentam rápido crescimento e tolerância a longos períodos de estiagem. As mudas, com cerca de 100 dias de idade, foram plantadas em ambas as áreas no espaçamento de 3,0 m entre plantas e 3,0 m na entre linha de plantio.

As parcelas experimentais foram constituídas por seis linhas de plantio com seis plantas cada, totalizando $486 \mathrm{~m}^{2}$, sendo duas linhas externas de cada lado e duas plantas nas extremidades das linhas internas, consideradas bordadura, totalizando $72 \mathrm{~m}^{2}$ de área útil.

Os tratamentos experimentais foram divididos em dois grupos. No primeiro, as plantas de eucalipto conviveram com a comunidade infestante por períodos crescentes desde o plantio. Após o término de cada período, a cultura foi mantida no limpo até o final do primeiro ano (364 dias). Os períodos estudados foram: $0,28,56,84,112,140,168,252$ e 364 dias a partir do plantio, conforme descritos na Tabela 8. No segundo grupo, as plantas daninhas foram controladas por períodos crescentes na cultura do eucalipto, desde o plantio. Ao final de cada período as plantas daninhas que emergiram foram deixadas crescer livremente. Os períodos estudados neste grupo foram idênticos ao grupo anterior (Tabela 8).

No campo, os tratamentos foram dispostos no delineamento de blocos ao acaso, com quatro repetições. Os dados obtidos foram submetidos pelo teste $F$ aplicado àanálise de variância, e as médias individuais foram confrontadas pelo teste de comparação múltipla de Tukey a $5 \%$ de probabilidade. Para a determinação dos períodos de interferência, os dados de diâmetro do caule, diâmetro medido a altura do peito (D.A.P.), altura, volume e incremento médio anual de madeira (I.M.A.) das plantas de eucalipto foram submetidos àanálise de regressão e representados graficamente, segundo modelo sigmoidal de Boltzmann, adaptado por Toledo (1998), sendo a equação geral: $\mathbf{Y}=\left(\mathbf{A}_{1}-\mathbf{A}_{2}\right) /$ $\left\{1+\exp \left[\left(\mathbf{x}-\mathbf{x}_{0}\right) / \mathbf{d x}\right]\right\}+\mathbf{A}_{2}$ (Figura 4). Os limites dos períodos de interferência foram 
determinados tolerando-se perdas máximas de produção de 2 e $5 \%$ em relação àquela obtida nas parcelas mantidas no limpo durante o primeiro ano do ciclo da cultura.

Para a limpeza das parcelas ao término de cada período experimental e sua manutenção dessa forma foram realizados o coroamento com capina manual nas proximidades das plantas de eucalipto e aplicações de 1,08 kg e.a. de glyphosate.ha ${ }^{-1}$, efetuadas nas entre linhas com pulverizador costal, em jato dirigido, utilizando-se bicos tipo espuma, regulado para um consumo de calda de 300 L.ha $^{-1}$.

Tabela 8. Descrição dos tratamentos experimentais. Três Lagoas, MS e Brotas, $\mathrm{SP}$.

\begin{tabular}{ccc}
\hline TRATAMENTOS & \multicolumn{2}{c}{ Períodos Iniciais } \\
& SEM CONTROLE & COM CONTROLE \\
\hline 1. & 0 * & $0-364$ \\
2. & $0-28$ & $28-364$ \\
3. & $0-56$ & $56-364$ \\
4. & $0-84$ & $84-364$ \\
5. & $0-112$ & $112-364$ \\
6. & $0-140$ & $140-364$ \\
7. & $0-168$ & $168-364$ \\
8. & $0-252$ & $252-364$ \\
9. & $0-364$ & 0 \\
10. & $28-364$ & $0-28$ \\
11. & $56-364$ & $0-56$ \\
12. & $84-364$ & $0-84$ \\
13. & $112-364$ & $0-112$ \\
14. & $140-364$ & $0-140$ \\
15. & $168-364$ & $0-168$ \\
16. & $252-364$ & $0-252$ \\
\hline
\end{tabular}

- Em número de dias após o plantio.

No ensaio localizado em Três Lagoas, MS foram avaliadas as oito plantas de eucalipto da área útil de cada parcela experimental quanto à altura aos 17 meses de idade. Aos 23, 30, 37 e 50 meses foram mensurados também o 
diâmetro medido a altura do peito (D.A.P.), altura, volume e incremento médio anual de madeira (I.M.A.), enquanto, em Brotas, SP, essas avaliações foram realizadas aos 24,37 e 48 meses após o plantio.

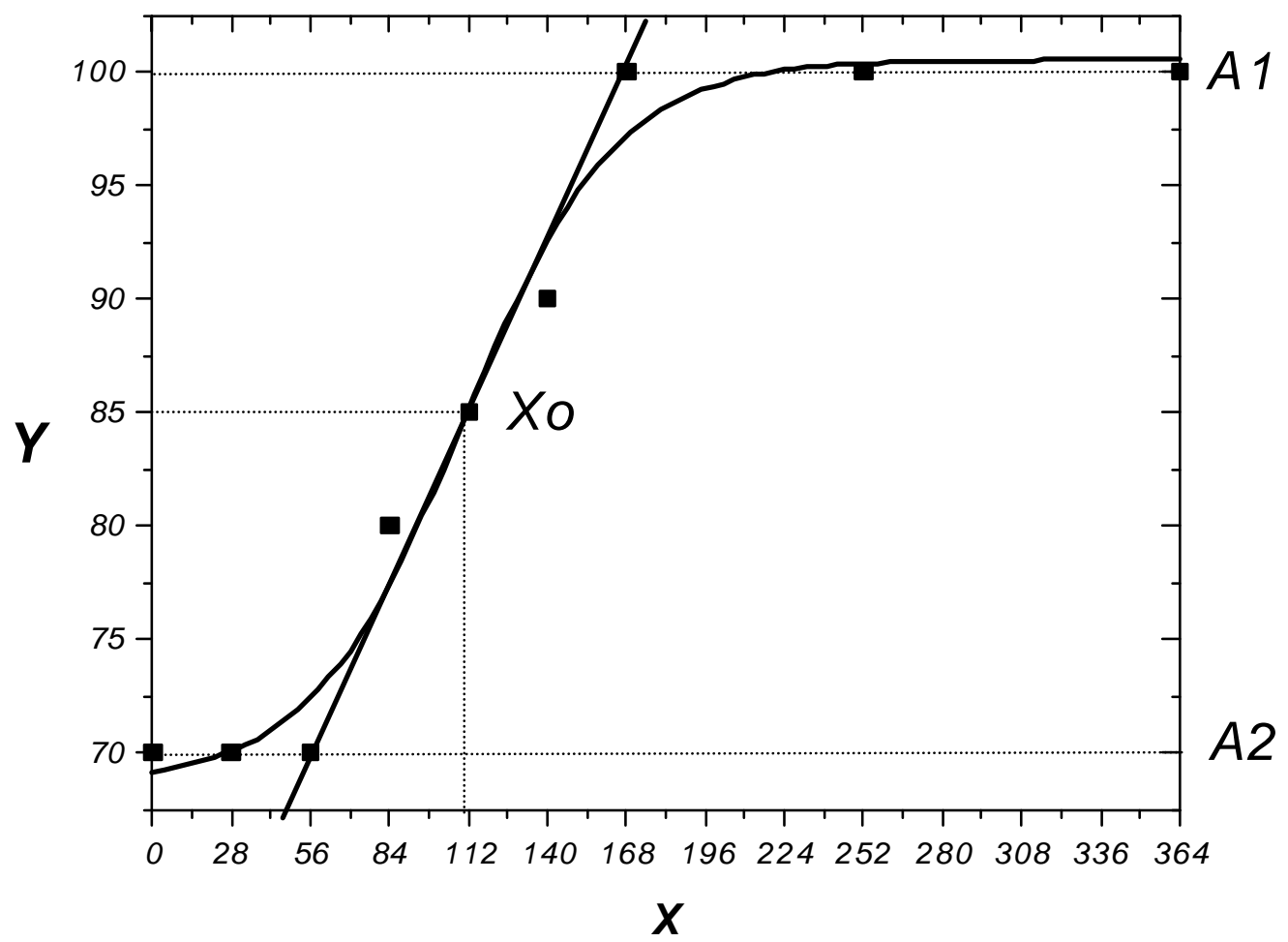

controle ou convivência

$$
Y=\frac{\left(A_{1}-A_{2}\right)}{1+e^{(X-X o) / d X}}+A_{2}
$$

Figura 4 - Representação gráfica e matemática do modelo sigmoidal de Boltzmann utilizado no ajuste dos dados de altura, D.A.P., volume e I.M.A. de madeira das plantas de eucalipto sob diferentes períodos de controle das plantas daninhas. Onde: 
$\boldsymbol{Y} \quad=$ produção das plantas de eucalipto em função dos períodos de controle ou de convivência.

$\boldsymbol{X}=$ limite superior do período de controle ou de convivência.

$\boldsymbol{A}_{1}=$ produção máxima obtida nas parcelas mantidas no limpo durante 0 desenvolvimento das plantas de eucalipto.

$\boldsymbol{A}_{2}=$ produção mínima obtida nas parcelas mantidas no limpo durante 0 desenvolvimento das plantas de eucalipto.

$\left(\boldsymbol{A}_{1}-\boldsymbol{A}_{2}\right)$ = perda de produção.

$\boldsymbol{X}_{\boldsymbol{0}} \quad=$ limite superior do período de controle ou de convivência, que corresponde ao valor intermediário entre a produção máxima e mínima.

$\boldsymbol{D X} \quad=$ parâmetro que indica velocidade de perda ou ganho de produção (tg á no ponto $\left.\mathrm{X}_{0}\right)$.

$\mathrm{Na}$ área útil de cada parcela experimental foi amostrado $1,5 \mathrm{~m}^{2}$ da comunidade infestante, correspondendo a seis amostras de $0,25 \mathrm{~m}^{2}$, das quais três amostras foram realizadas na linha e três na entre linha de plantio do eucalipto. As espécies de plantas daninhas presentes nas amostras foram identificadas, contadas e levadas ao Laboratório do Departamento de Biologia Aplicada à Agropecuária da Faculdade de Ciências Agrárias e Veterinárias de Jaboticabal, UNESP, onde foram lavadas e secas em estufa com renovação de ar a $70^{\circ} \mathrm{C}$ por 96 horas. Após este procedimento, foi determinada a biomassa seca da parte aérea das plantas coletadas, utilizando balança eletrônica com precisão de 0,01 g.

\subsection{Resultados e Discussão}

O capim-braquiária foi à população predominante em Três Lagoas, MS, acumulando, em média, 1556,1 g.m $\mathrm{m}^{-2}$ da biomassa seca na área total da parcela da testemunha "no mato", distribuída da seguinte forma: 546,7 g. $\mathrm{m}^{-2}$ na linha e 1009,5 g. $\mathrm{m}^{-2}$ na entre linha de plantio do eucalipto. Por outro lado, a comunidade 
infestante foi constituída ainda por tiririca, erva-quente, guanxuma (Sida rhombifolia L.), guanxuma-branca (Sida galziovii K. Schum), guanxuma-dourada (Sida urens L.) e algumas rebrotas de cerrado, e acumulou, em média 1652,1 g.m ${ }^{2}$, sendo 561,6 g.m ${ }^{-2}$ na linha e 1090,6 g.m $\mathrm{m}^{-2}$ na entre linha de plantio (Figura 5).

Nesta área, a densidade média do capim-braquiária observada nas parcelas em que as plantas de eucalipto conviveram por 364 dias com a comunidade infestante, foi aproximadamente de 32 plantas. $\mathrm{m}^{-2}$ na área total, distribuídas em 16 plantas. $\mathrm{m}^{-2}$ na linha e na entre linha de plantio do eucalipto (Figura 5). Já a densidade total da comunidade infestante em área total foi de 40 plantas. $\mathrm{m}^{-2}$, distribuídas uniformemente na linha e na entre linha da cultura (20 plantas. $\mathrm{m}^{-2}$ ), conforme pode ser observado na Figura 5 .

No entanto, em Brotas, SP, as plantas daninhas estavam distribuídas em reboleiras, provavelmente devido à presença de restos culturais do e ucalipto. As populações mais freqüentes nesta área (capim-braquiária, capim-favorito, capimamargoso e capim-gordura) acumularam, em média, $613,5 \mathrm{~g} \cdot \mathrm{m}^{-2}$ da biomassa

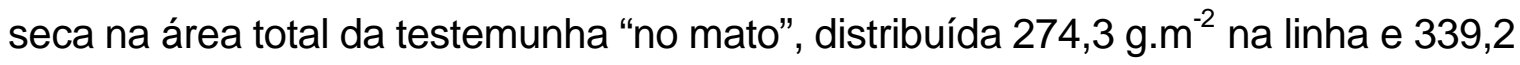
$\mathrm{g} \cdot \mathrm{m}^{-2}$ na entre linha da cultura, enquanto, as demais plantas daninhas acumularam em média, 450,1 g.m ${ }^{-2}$, sendo $74,7 \mathrm{~g} \cdot \mathrm{m}^{-2}$ na linha e $375,4 \mathrm{~g} \cdot \mathrm{m}^{-2}$ na entre linha de plantio (Figura 6)

A densidade média da comunidade infestante presente em Brotas, SP, encontrada nas parcelas em que as plantas de eucalipto conviveram por 364 dias com as plantas daninhas, foi aproximadamente de 70,5 plantas. $\mathrm{m}^{-2}$ na área total, distribuídas em 24 plantas. $\mathrm{m}^{-2}$ na linha e 46,5 plantas. $\mathrm{m}^{-2}$ na entre linha de plantio do eucalipto (Figura 6). Já a densidade média das monocotiledôneas na área total das parcelas foi de 45 plantas. $\mathrm{m}^{-2}$, distribuídas uniformemente na linha e na entre linha da cultura, enquanto a densidade média das dicotiledôneas foi de 25,5 plantas. $\mathrm{m}^{-2}$, (1,5 e 24 plantas. $\mathrm{m}^{-2}$ na linha e entre linha, respectivamente). 

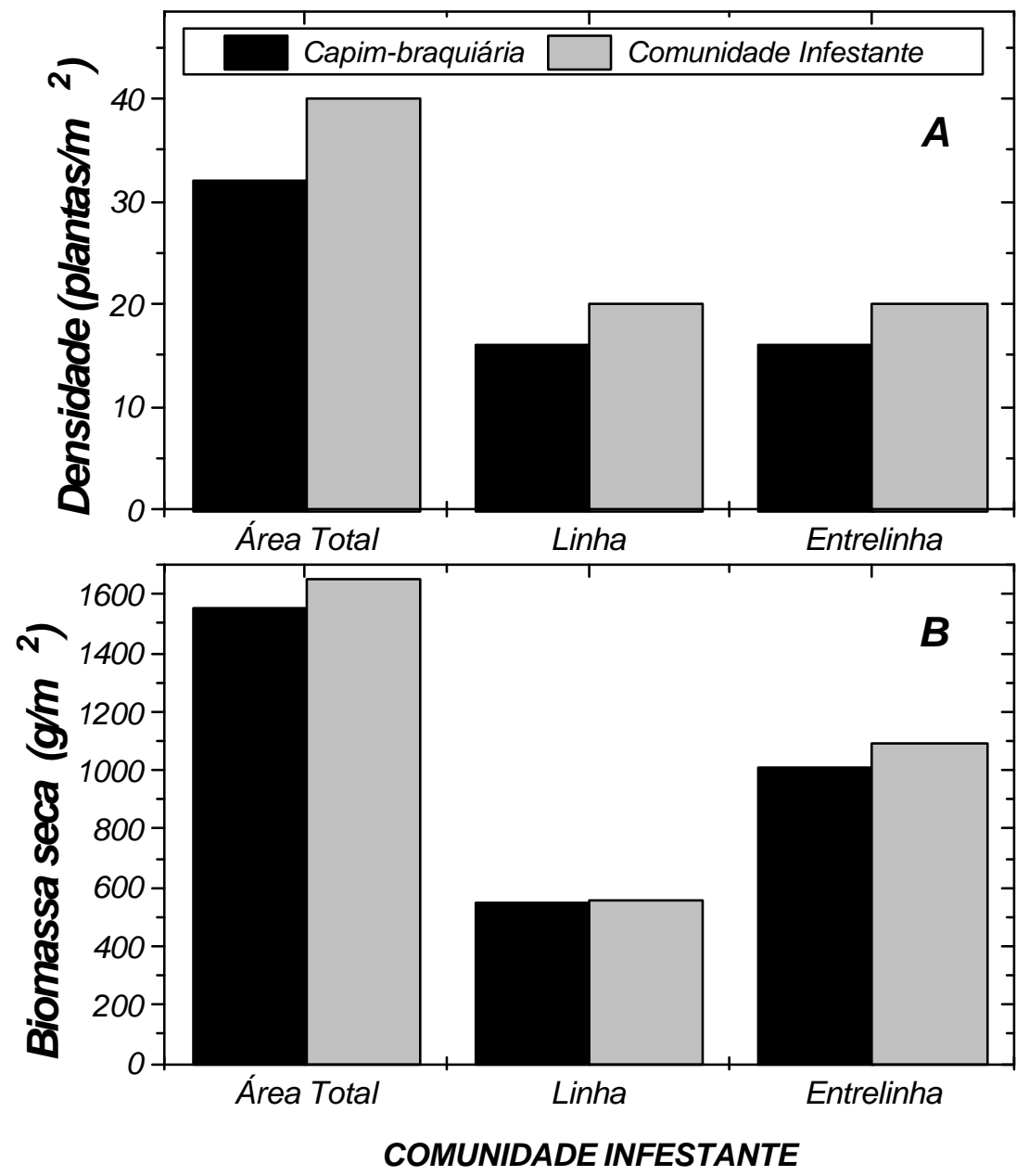

Figura 5 - Densidade média (plantas. $\mathrm{m}^{-2}$ ) e biomassa seca acumulada $\left(\mathrm{g} \cdot \mathrm{m}^{-2}\right)$ do capim-braquiária em relação à comunidade infestante presente nas parcelas nas quais as plantas de eucalipto conviveram com a comunidade infestante até 364 dias após o plantio. Três Lagoas, MS. 

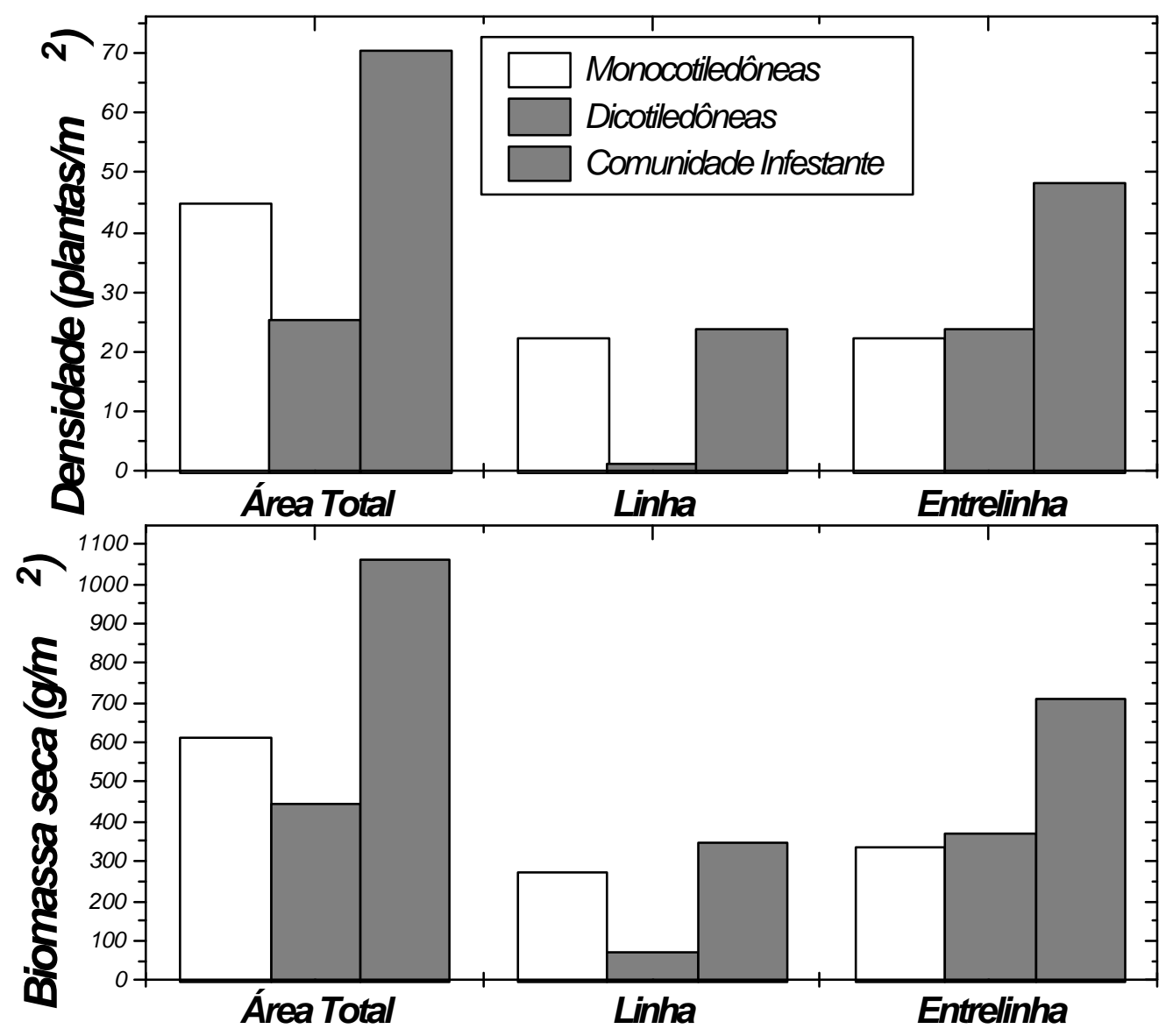

Figura 6 - Densidade média (plantas. $\mathrm{m}^{-2}$ ) e biomassa média seca acumulada ( $\mathrm{g} \cdot \mathrm{m}^{-}$ $\left.{ }^{2}\right)$ das principais espécies de plantas daninhas presentes nas parcelas nas quais as plantas de eucalipto conviveram com a comunidade infestante por 364 dias após o plantio. Brotas, SP. 
Bezutte et al., (1995a) observaram que a partir de 4 plantas. $\mathrm{m}^{-2}$, o capimbraquiária interfere significativamente no crescimento inicial das mudas de eucalipto, reduzindo em média $28 \%$ o diâmetro do caule e $18 \%$ a altura das plantas, aos 190 dias após o plantio.

Conforme Costa (1999), a partir de 4 plantas. $\mathrm{m}^{-2}$ a erva-quente já interfere negativamente sobre o crescimento inicial do eucalipto, reduzindo em média $44,4 \%$ na área foliar, $35,2 \%$ e $42,2 \%$ na biomassa seca de caule e de ramos nas condições de inverno, enquanto nas condições de verão, essas reduções foram de $20,6 \%$ no diâmetro do caule, 50,8\% na área foliar, 33,4\%, 49,5\% e 48,3\% na biomassa seca do caule, de ramos e de folhas. Pelos dados da literatura apresentada, pode-se inferir que as densidades médias observadas nas áreas experimentais justificam a necessidade de controle das plantas daninhas.

Aos 364 dias após o plantio da área de Três Lagoas, MS, as plantas de eucalipto que conviveram com a comunidade infestante durante o primeiro ano (364 dias), apresentaram diâmetro médio de 2,1 cm e altura de 1,6 m, o que representam 68,2\% e 65,7\% de redução em relação æ̀ plantas de eucalipto que cresceram livres da interferência das plantas daninhas que apresentaram diâmetro e altura de 6,7 cm e 4,7 m, respectivamente (Toledo et al., 2000). Essas diferenças foram devido à alta pressão de interferência exercida pelas plantas daninhas, especialmente o capim-braquiária. Esta resposta em relação àaltura do eucalipto não era esperada, uma vez que a altura não constitui característica adequada para avaliação dos dados de competição (Rodrigues et al., 1991).

Desse modo, Pitelli \& Marchi (1991) comentam que sob intensa infestação de plantas daninhas o eucalipto tende a perder rapidamente os ramos e folhas da base da copa, apresentando, com isso, pequena quantidade de folhas concentradas no topo da muda, provocando o estiolamento da muda, devido à interceptação de luz que restringe a fonte predominante de energia aos processos básicos de recrutamento de elementos e de elaboração de todas as substâncias envolvidas no crescimento do vegetal. 
O período a partir do plantio da cultura no qual as plantas daninhas devem ser controladas para que o desenvolvimento inicial do eucalipto não seja afetado significativamente observado por Toledo et al. (2000) e denominado por Pitelli \& Durigan (1984) de período total de prevenção àinterferência (PTPI) foi de 140 dias, quando se considera redução de $5 \%$ em diâmetro do caule e altura das plantas de eucalipto em Três Lagoas, MS. Já o período anterior àinterferência (PAI) foi de 14 e 28 dias, quando se considera o diâmetro do caule e a altura, respectivamente.

Apesar da pequena diferença observada na porcentagem de redução em diâmetro $(68,2 \%)$ e em altura $(65,7 \%)$, pode-se dizer que aos 12 meses após o plantio em Três Lagoas, MS, o diâmetro foi mais afetado pela presença das plantas daninhas do que a altura da cultura. O diâmetro passou a ser expressivamente influenciado pela comunidade infestante a partir dos 14 dias após o plantio, enquanto a altura das plantas de eucalipto a partir dos 28 dias (Toledo et al., 2000).

No entanto, ao analisar os dados de altura aos 17 meses e os dados de altura e D.A.P. aos 23, 30, 37 e 50 meses nessa área, observa-se àtendência de recuperação das plantas de eucalipto que conviveram com a comunidade infestante durante o primeiro ano de desenvolvimento da cultura, àmedida que os períodos totais de prevenção àinterferência (PTPI), apresentados na Tabela 9, são inferiores ao PTPI de 140 dias estimado por Toledo et al. (2000).

Aos 17 meses após o plantio desta área pode-se notar que o PTPI foi de 90 e 60 dias, quando se considera 2 e $5 \%$ de redução em altura das plantas de eucalipto, respectivamente (Tabela 9). Nesta época, as plantas de eucalipto que conviveram com as plantas daninhas apresentaram altura média de 4,4 m, enquanto nas plantas de eucalipto que cresceram livres da interferência da comunidade infestante à altura foi de $8,3 \mathrm{~m}$, o que repres enta $52,5 \%$ de redução (Tabela 10). 
Tabela 9. Variação do período total de prevenção à interferência em função das porcentagens de redução em altura, D.A.P., volume e I.M.A. de madeira das plantas de eucalipto. Três Lagoas, MS e Brotas, SP.

\begin{tabular}{ccccccccc}
\hline & \multicolumn{1}{c}{ ALTURA } & \multicolumn{9}{c}{ D.A.P. } & \multicolumn{2}{c}{ VOLUME } & \multicolumn{2}{c}{ I.M.A. } \\
MESES & $2 \%$ & $5 \%$ & $2 \%$ & $5 \%$ & $2 \%$ & $5 \%$ & $2 \%$ & $5 \%$ \\
\hline 17 & 90 & 60 & $\# \# \#$ & $\# \# \#$ & $\# \#$ & $\# \#$ & $\# \# \#$ & $\# \#$ \\
23 & 50 & 31 & 34 & 28 & 268 & 200 & 256 & 196 \\
30 & 17 & 9 & 25 & 14 & 224 & 150 & 221 & 152 \\
37 & 16 & 14 & 40 & 21 & 205 & 178 & 219 & 180 \\
50 & 15 & 7 & 40 & 21 & 210 & 180 & 205 & 170 \\
& & & & BROTAS, SP & & & \\
24 & 37 & 36 & 57 & 56 & 62 & 60 & 58 & 57 \\
37 & 54 & 53 & 44 & 43 & 42 & 40 & $\# \#$ & $\# \#$ \\
48 & 43 & 42 & 44 & 43 & 35 & 34 & 50 & 47 \\
\hline
\end{tabular}

\#\#\# Não avaliado.

Aos 23 e 30 meses após o plantio, as plantas de eucalipto que conviveram com a comunidade infestante por 364 dias em Três Lagoas, MS, apresentaram D.A.P. médio de 6,5 e $8,7 \mathrm{~cm}$ e altura média de 7,8 e 12,3 $\mathrm{m}$, respectivamente, enquanto as plantas que cresceram livres da presença das plantas daninhas apresentaram D.A.P. médio de 9,2 e 10,0 cm e altura média de 10,5 e 13,8 m, o que representam 29,7 \%, 13,3\%, 25,9\% e 10,1\% de redução, respectivamente, sugerindo mais uma vez a tendência de recuperação das plantas de eucalipto a essa interferência (Tabela 10). 
Na Tabela 11, verifica-se que as plantas de eucalipto de Três Lagoas, MS, que conviveram com a comunidade infestante durante 0 primeiro ano apresentaram aos 23 e 30 meses volume médio de 17,6 e $41,6 \mathrm{~m}^{3}$.ha ${ }^{-1}$ e I.M.A. de 9,2 e 16,6 $\mathrm{m}^{3}$.ha ${ }^{-1}$.ano ${ }^{-1}$, enquanto as plantas de eucalipto que cresceram na testemunha no limpo apresentaram volume de 35,1 e $55,3 \mathrm{~m}^{3}$.ha-1 e I.M.A. de 18,3 e $22,1 \mathrm{~m}^{3}$.ha ${ }^{-1}$.ano ${ }^{-1}$, o que representam $49,8 \%, 24,8 \%, 49,8 \%$ e $24,8 \%$ de redução em relação æ̀ plantas de eucalipto das parcelas nas quais as plantas daninhas foram controladas por todo o período experimental, respectivamente, confirmando assim a hipótese da capacidade de recuperação das plantas de eucalipto.

De acordo com Gonçalves et al., (2000) nos três primeiros meses de crescimento das mudas de eucalipto no campo as taxas de absorção de nutrientes são pequenas. Neste período, as mudas de eucalipto alocam grande quantidade de fotoassimilados e nutrientes para a síntese de raízes para assegurar o suprimento de água e nutrientes. Por este motivo, se desenvolvem menos, e portanto podem mostrar sintomas de deficiências nutricionais.

Posteriormente, com os suprimentos de água e nutrientes assegurados, a atividade fotossintética é intensificada, havendo grande expansão da área foliar e maior crescimento epígeo das mudas de eucalipto. A seguir ocorre uma fase de intenso crescimento e acúmulo de nutrientes, com elevadas taxas de absorção que se relacionam diretamente com a idade da cultura. Neste período, as plantas de eucalipto estão mais sensíveis àcompetição das plantas daninhas, pois todos os fotoassimilados são sintetizados para a formação de copas (expansão da área foliar) e sistema radicular, principalmente raízes finas (raízes com função de absorção de água e nutrientes). O sistema radicular explora parcialmente o volume do solo e as árvores não competem entre si por fatores de crescimento (luz, nutrientes, espaço e água), sendo seu crescimento limitado pelas próprias condições fisiológicas e pelos inimigos naturais, incluindo as plantas daninhas (Gonçalves et al., 2000). 
A intensa resposta àfertilização neste estágio de desenvolvimento é muito comum. Nestas situações, as taxas de absorção de nutrientes e a atividade metabólica dos componentes das árvores são elevadas, podendo ser aumentados o tempo de retenção das folhas e a eficiência fotossintética por unidade de área foliar (Gonçalves et al., 2000).

Sob baixas disponibilidades de água e nutrientes, as plantas daninhas podem competir com as plantas de eucalipto, podendo gerar deficiências principalmente na fase de estabelecimento das florestas. Uma das razões do grande poder competitivo dessas plantas daninhas está relacionada a grande capacidade de adaptação das populações infestantes às condições ambientais do sítio (Silva et al., 1997). Portanto, pode-se justificar o efeito mais severo das plantas daninhas nas fases iniciais de desenvolvimento do eucalipto.

Em Brotas, SP, aos 24 meses as plantas de eucalipto que conviveram com as plantas daninhas por 364 dias apresentaram D.A.P. médio de 7,7 cm, altura de $8,8 \mathrm{~m}$, volume de $22,4 \mathrm{~m}^{3}$.ha ${ }^{-1}$ e I.M.A. de $11,2 \mathrm{~m}^{3} \mathrm{ha}^{-1}$.ano ${ }^{-1}$ o que representam $5,2 \%, 7,6 \%, 7,5 \%$ e $7,4 \%$ de redução em relação às plantas de eucalipto que cresceram livres da interferência da comunidade infestante, que apresentaram $8,1 \mathrm{~cm}, 9,5 \mathrm{~m}, 24,2 \mathrm{~m}^{3} \cdot$ ha $^{-1}$ e $12,1 \mathrm{~m}^{3} \mathrm{ha}^{-1}$.ano ${ }^{-1}$, respectivamente (Tabela 12).

Já aos 37 meses após o plantio desta área, as plantas de eucalipto que conviveram com a comunidade infestante durante 0 primeiro ano de desenvolvimento da cultura apresentaram valores de D.A.P., altura, volume de madeira e I.M.A. de $9,8 \mathrm{~cm}, 13,6 \mathrm{~m}, 58,1 \mathrm{~m}^{3} \mathrm{ha}^{-1}$ e 18,9 m $\mathrm{ma}^{-1}$.ano ${ }^{-1}$, respectivamente, o que representam reduções de $0,2 \%$ do D.A.P., $6,0 \%$ da altura, $0,3 \%$ do volume de madeira e $0,3 \%$ do I.M.A., quando comparadas com as plantas de eucalipto que cresceram na testemunha no limpo, que apresentaram 9,9 cm, 14,5 m, 58,3 $\mathrm{m}^{3} \mathrm{ha}^{-1} \cdot$ ano $^{-1}$ e 18,9 $\mathrm{m}^{3} \mathrm{ha}^{-1}$.ano ${ }^{-1}$, respectivamente (Tabela 12). 
Já aos 48 meses após o plantio da área de Brotas, SP, as plantas de eucalipto que conviveram com a comunidade infestante durante os primeiros 364 dias de desenvolvimento da cultura apresentaram valores de D.A.P., altura, volume e I.M.A. de $11,1 \mathrm{~cm}, 17,0 \mathrm{~m}, 94,2 \mathrm{~m}^{3} \mathrm{ha}^{-1}$ e 23,6 $\mathrm{m}^{3} \mathrm{ha}^{-1}$.ano ${ }^{-1}$, respectivamente, o que representam reduções de $1,51 \%$ do D.A.P., $1,61 \%$ da altura, e aumento da produtividade de $3,5 \%$ do volume e $3,5 \%$ do I.M.A. das plantas de eucalipto que cresceram livres da interferência das plantas daninhas, que apresentaram $11,3 \mathrm{~cm}$, 17,3 m, 94,2 $\mathrm{m}^{3} \mathrm{ha}^{-1}$ e 23,56 $\mathrm{m}^{3} \mathrm{ha}^{-1}$.ano ${ }^{-1}$, respectivamente (Tabela 13), o que sugere as hipóteses: a baixa interferência imposta pela comunidade infestante devido à distribuição irregular das plantas daninhas na área (reboleiras), a recuperação das plantas de eucalipto ao efeito dessa interferência, bem como o potencial alelopático dos restos culturais do eucalipto (galhos, cascas, ramos e serrapilheira) reduzindo o efeito da interferência das plantas daninhas.

Para a área de Três Lagoas, MS, pode-se observar aos 50 meses que as plantas de eucalipto da testemunha no mato apresentaram valores de altura, D.A.P., volume e I.M.A. de 17,8 m, 11,3 cm, 96,3 $\mathrm{m}^{3} \mathrm{ha}^{-1}$ e 23,1 $\mathrm{m}^{3} \mathrm{ha}^{-1}$.ano ${ }^{-1}$, enquanto as plantas da testemunha no limpo $19,22 \mathrm{~m}, 12,80 \mathrm{~cm}, 124,63 \mathrm{~m}^{3} \mathrm{ha}^{-1} \mathrm{e}$ $29,9 \mathrm{~m}^{3} \mathrm{ha}^{-1}$.ano ${ }^{-1}$, respectivamente, o que representam: $7,4 \%, 11,5 \%, 22,7 \%$ e $22,7 \%$ de redução.

Aos 24 meses após o plantio de Brotas, SP foram obtidos os valores de PTPI iguais a: 56, 36, 60 e 57 dias, quando se considera redução de 5\% em DAP, em altura, volume de madeira ou I.M.A. das plantas de eucalipto, respectivamente (Tabela 9).

No entanto, quando estas características são analisadas nas plantas de eucalipto aos 48 meses após o plantio verifica-se que o PTPI foi reduzido para 43 dias para D.A.P. e 34 dias para volume de madeira, enquanto em relação àaltura das plantas de eucalipto o PTPI evolui para 48 dias, sendo interessante ressaltar que para o incremento médio anual não foi possível determinar 
o PTPI, em função do não ajuste das curvas de convivência e de controle (Tabela 9).

Pode-se notar na Tabela 9, quando estas características são analisadas nas plantas de eucalipto aos 48 meses após o plantio de Brotas, SP, o PTPI foi mantido em 43 dias para D.A.P. e foi reduzido para 42 dias, 34 dias e 47 dias em relação à altura, volume de madeira e I.M.A. das plantas de eucalipto, respectivamente, quando comparados aos valores de PTPI observados aos 24 e 37 meses após o plantio, respectivamente.

Já aos 37 e 50 meses dias após o plantio os valores de PTPI observados são inferiores aos analisados aos 23 e 30 meses, ou seja, 14 e 7 dias para altura, 21 e 20 dias para D.A.P., 180 dias para volume de madeira e 180 e 170 dias para I.M.A., quando considera-se $5 \%$ de redução. No entanto, quando o limite de tolerância máximo nas perdas é de 2\% o PTPI foi de 16 e 15 dias para altura, 40 e 40 dias para D.A.P., 205 e 210 dias para volume e 219 e 205 dias para I.M.A., sugerindo o deslocamento do PTPI em função do tempo e conseqüente recuperação das plantas de eucalipto a interferência das plantas daninhas.

Em resumo, pode-se questionar o efeito da interferência da comunidade infestante presente no município de Brotas, SP sobre o desenvolvimento inicial e a produtividade do eucalipto, principalmente quando as plantas daninhas estão distribuídas irregularmente (reboleiras) no campo, o que pode ser explicado pelo potencial alelopático dos restos culturais (galhada e serrapilheira), bem como a recuperação das plantas de eucalipto em relação a essa interferência a partir dos 37 meses após o plantio. Pode-se afirmar, ainda, que a seleção de clones de eucalipto, espaçamento e as operações de preparo da área, adubação de plantio e cobertura permitiram que a cultura do eucalipto estivesse bem estabelecida nesta área experimental, favorecendo assim um perfeito crescimento inicial e rápido sombreamento das plantas daninhas, o que pode explicar a baixa porcentagem de redução exercida pela comunidade infestante na cultura do eucalipto. 
De modo geral, poder-se-ia dizer que, quanto maior for o período de convivência entre a cultura do eucalipto e a comunidade infestante, maior seria o grau de interferência. No entanto, segundo Pitelli (1987), isto não é totalmente válido, porque dependerá da época do ciclo da cultura em que este período for considerado, o que pode ser observado pelos resultados obtidos na presente pesquisa.

$\mathrm{Na}$ cultura de Eucalyptus sp. poucos são os estudos sobre os períodos considerados críticos nas relações de interferência com as plantas daninhas (Toledo, 1999).

Os períodos encontrados por diferentes autores como Andrade (1961), Osse (1961), Pitelli et al., (1988), Rodrigues et al., (1991), Bezutte et al., (1995b), Marchi (1996) e Toledo et al., (2000) não são iguais, o que pode ser explicado pelo fato das condições de condução dessas pesquisas, as próprias espécies ou clones utilizados e as composições específicas das comunidades infestantes serem diferentes e que dada a esta diversidade, torna-se fundamental que estas pesquisas se intensifiquem e ultrapassem os limites das universidades, sendo executadas pelas empresas florestais que visam obter informações mais significativas para as suas áreas de produção.

Bezutte et al., (1995b), considerando plantas de E. grandis com três anods de idade (1110 dias), verificaram que estas plantas durante a fase inicial de desenvolvimento podiam conviver com o capim-braquiária (B. decumbens Stapf) e o capim-braquiarão [B. brizantha (Hochst.) Stapf] até 56 dias sem comprometer a sua produção aos 48 meses de idade (PAl). Por outro lado, foi necessário que a cultura fosse mantida "no limpo" por um período de 168 dias para que a sua produtividade, aos 48 meses, não fosse comprometida (PTPI). Os resultados observados por estes autores evidenciaram a grande interferência promovida por essas plantas daninhas no início de desenvolvimento da cultura do eucalipto. 
Marchi (1996) observou que os maiores ganhos de crescimento da cultura do eucalipto foram obtidos com o controle do capim-colonião (Panicum maximum Jacq.) nos primeiros 100 a 120 dias. As plantas de eucalipto que conviveram com períodos superiores a 84 dias apresentaram redução de produção de madeira de até $67 \%$ aos 22 meses de idade e $50 \%$ aos 32 meses. A análise de custo benefício, realizada pelo autor, revelou que uma capina manual logo no início da instalação da cultura com duas subseqüentes aplicações de oxyfluorfen, visando um período residual acima de 100 dias, proporcionou aceitável produção de madeira a um baixo custo, gerando uma relação custo benefício positiva já aos 32 meses de idade da cultura, quando comparada com a testemunha que conviveu na presença das plantas daninhas por 364 dias.

Toledo et al., (1996) constataram que a atividade mais onerosa no primeiro ano de implantação de E. grandis é o controle das plantas daninhas. Nesta pesquisa, o controle do capim-braquiária na entre linha de plantio com quatro capinas manuais representou $30,7 \%$ dos custos totais de implantação, enquanto que o controle químico com glyphosate em três ocasiões representou $17,3 \%$ do total gasto. Esses autores ainda observaram que, de maneira geral, os custos de controle das plantas daninhas totalizaram cerca de $66 \%$ do custo total de implantação da floresta, independente do manejo adotado.

\subsection{Conclusões}

Pelos resultados obtidos nesta pesquisa, pode-se concluir que:

No município de Três Lagoas, MS, é necessário um período de 180 dias de controle para obter apenas $5 \%$ de redução em volume de madeira aos 50 meses, o que sugere que a determinação do período total de prevenção à interferência (PTPI) deverá ser o mais próximo possível da realização da colheita da cultura. 
O PTPI recomendado para o município de Brotas, SP é de 34 dias, considerando o índice de 5\% de redução em volume de madeira aos 48 meses, período no qual a interferência foi significativa. 
Tabela 10. Efeito dos períodos de controle das plantas daninhas sobre a altura e D.A.P. de plantas de eucalipto. Três Lagoas, MS.

\begin{tabular}{|c|c|c|c|c|c|c|c|c|c|}
\hline \multicolumn{10}{|c|}{ Meses após o plantio } \\
\hline \multirow[b]{2}{*}{ Trat. } & \multicolumn{5}{|c|}{ Altura (m) } & \multicolumn{4}{|c|}{ D.A.P. $(\mathrm{cm})$} \\
\hline & 17 & 23 & 30 & 37 & 50 & 23 & 30 & 37 & 50 \\
\hline $\mathrm{T} 1$ & $8,32 a b c^{1}$ & $10,54 a b$ & $13,73 \mathrm{abc}$ & 15,49 abcd & $19,22 \mathrm{a}$ & $9,18 \mathrm{ab}$ & $10,02 \mathrm{abcd}$ & $11,51 \mathrm{abc}$ & $12,80 \mathrm{ab}$ \\
\hline $\mathrm{T} 2$ & $8,10 a b c$ & $11,00 \mathrm{a}$ & $14,56 a b$ & $15,66 a b c$ & $19,69 \mathrm{a}$ & $9,15 a b$ & $10,71 \mathrm{abcd}$ & $11,40 a b c$ & $13,19 a b$ \\
\hline T3 & $7,57 \mathrm{abc}$ & $10,62 a b$ & $14,76 a b$ & $15,44 \mathrm{abcd}$ & $19,46 \mathrm{a}$ & $8,79 a b c$ & $10,96 a b$ & $11,14 a b c$ & $12,77 a b$ \\
\hline T4 & $7,66 \mathrm{abc}$ & $10,37 a b$ & $13,93 a b c$ & $15,01 \mathrm{abcd}$ & $18,93 \mathrm{a}$ & $8,32 \mathrm{abcd}$ & 10,09 abcd & $10,66 a b c$ & $12,74 a b$ \\
\hline T5 & $7,01 \mathrm{bcd}$ & $9,97 \mathrm{abc}$ & $13,23 a b c$ & $15,02 \mathrm{abcd}$ & $19,10 \mathrm{a}$ & $8,45 \mathrm{abcd}$ & $9,80 \mathrm{abcd}$ & $10,88 a b c$ & $12,68 a b$ \\
\hline T6 & 5,84 def & $9,30 \mathrm{bcd}$ & $13,19 a b c$ & $13,86 \mathrm{bcd}$ & $17,85 a$ & 7,94 bcde & $9,74 \mathrm{abcd}$ & $10,19 \mathrm{bc}$ & $12,03 a b$ \\
\hline $\mathrm{T7}$ & 5,37 ef & 8,83 cde & $12,34 \mathrm{bc}$ & $13,77 \mathrm{dc}$ & $17,28 \mathrm{a}$ & 7,45 cde & $8,74 \mathrm{~cd}$ & $9,89 \mathrm{bc}$ & $11,90 a b$ \\
\hline T8 & $5,42 \mathrm{f}$ & 8,55 de & $12,86 \mathrm{bc}$ & $13,65 d$ & $18,15 \mathrm{a}$ & $7,23 \mathrm{de}$ & $9,09 \mathrm{bcd}$ & $10,09 \mathrm{bc}$ & $11,96 a b$ \\
\hline $\mathrm{T9}$ & $4,37 \mathrm{f}$ & $7,81 \mathrm{e}$ & $12,34 \mathrm{c}$ & $13,73 d$ & $17,79 \mathrm{a}$ & $6,45 \mathrm{e}$ & $8,69 \mathrm{~d}$ & $9,73 \mathrm{c}$ & $11,33 \mathrm{~b}$ \\
\hline T10 & 7,22 bcd & $10,23 a b$ & $14,28 a b$ & $15,44 \mathrm{abcd}$ & $19,21 \mathrm{a}$ & $8,76 a b c$ & 10,36 abcd & $11,25 a b c$ & $12,83 a b$ \\
\hline $\mathrm{T} 11$ & $8,07 \mathrm{abc}$ & $10,71 \mathrm{a}$ & $14,44 a b$ & $15,46 \mathrm{abcd}$ & $19,34 \mathrm{a}$ & $9,15 a b$ & 10,45 abcd & $11,28 a b c$ & $12,83 a b$ \\
\hline T12 & 6,78 cde & $10,18 a b$ & $13,71 a b c$ & $14,78 \mathrm{abcd}$ & $18,86 \mathrm{a}$ & $8,61 \mathrm{abcd}$ & 9,83 abcd & $10,82 a b c$ & $12,67 a b$ \\
\hline $\mathrm{T} 13$ & 8,88 a & $10,97 \mathrm{a}$ & $14,55 a b$ & $15,68 a b$ & $19,96 \mathrm{a}$ & $9,64 \mathrm{a}$ & $10,97 a b$ & $12, .49 \mathrm{a}$ & $14,25 \mathrm{a}$ \\
\hline $\mathrm{T} 14$ & $8,39 a b$ & $10,71 \mathrm{a}$ & $14,48 a b$ & $15,22 \mathrm{abcd}$ & $18,91 \mathrm{a}$ & $8,53 \mathrm{abcd}$ & $10,16 \mathrm{abcd}$ & 10,89 abc & $12,33 a b$ \\
\hline $\mathrm{T} 15$ & $8,36 a b$ & $10,96 \mathrm{a}$ & $14,74 a b$ & $15,92 \mathrm{a}$ & $19,80 \mathrm{a}$ & $8,96 \mathrm{abc}$ & $10,74 \mathrm{abc}$ & $11,51 \mathrm{abc}$ & $13,29 a b$ \\
\hline T16 & $8,93 \mathrm{a}$ & $11,09 a$ & $15,03 \mathrm{a}$ & $15,98 \mathrm{a}$ & $19,58 \mathrm{a}$ & $9,53 \mathrm{a}$ & 11,18 a & $11,85 a b$ & $13,37 a b$ \\
\hline $\mathrm{F}$ & 20,23 ** & 14,02 ** & $5,31^{* *}$ & $4,78^{* *}$ & 2,22 NS & $8,17^{* *}$ & $3,73^{* *}$ & $3,36^{* *}$ & 1,96 * \\
\hline D.M.S. & 1,5639 & 1,3402 & 2,0702 & 1,8952 & 2,6901 & 1,5308 & 2,0288 & 2,0696 & 2,5197 \\
\hline C.V (\%) & 8,39 & 5,19 & 5,43 & 4,94 & 5,56 & 7,04 & 7,87 & 7,38 & 7,78 \\
\hline
\end{tabular}

1. Médias seguidas de mesma letra não diferem significativamente entre si pelo Teste de Tukey a de $1 \%$ de probabilidade; * nificativo pelo Teste $\mathrm{F}$ a $5 \%$ de probabilidade; ** Significativo pelo Teste $\mathrm{F}$ a de $1 \%$ de probabilidade. 
Tabela 11. Efeito dos períodos de controle das plantas daninhas sobre o volume e I.M.A. de plantas de eucalipto. Três Lagoas, MS.

\begin{tabular}{|c|c|c|c|c|c|c|c|c|}
\hline \multicolumn{9}{|c|}{ Meses após o plantio } \\
\hline \multirow[b]{2}{*}{ Trat. } & \multicolumn{4}{|c|}{ Volume $\left(m^{3} h a^{-1}\right)$} & \multicolumn{4}{|c|}{ I.M.A. $\left(m^{3} h^{-1} \cdot a^{-1}\right)$} \\
\hline & 23 & 30 & 37 & 50 & 23 & 30 & 37 & 50 \\
\hline $\mathrm{T} 1$ & $35,13 a b c$ & $55,29 a b c$ & $72,32 a b c$ & $124,63 \mathrm{abc}$ & $18,33 a b c$ & $22,11 a b c$ & $24,11 a b c$ & $29,91 a b c$ \\
\hline T2 & $33,98 \mathrm{abcd}$ & $57,38 a b c$ & $72,41 \mathrm{abc}$ & $118,94 \mathrm{abc}$ & $17,73 \mathrm{abcd}$ & $22,95 a b c$ & $24,14 a b c$ & $28,55 a b c$ \\
\hline T3 & $31,09 \mathrm{bcd}$ & $54,45 a b c$ & $67,23 \mathrm{abcd}$ & $114,61 \mathrm{abc}$ & $16,22 \mathrm{bcd}$ & $21,78 a b c$ & $20,75 \mathrm{abcd}$ & $27,51 a b c$ \\
\hline $\mathrm{T} 4$ & 28,43 bcde & $51,66 a b c$ & $62,26 \mathrm{abcd}$ & $111,88 a b c$ & 14,83 bcde & $20,66 a b c$ & $22,12 \mathrm{abcd}$ & $26,85 a b c$ \\
\hline T5 & $31,58 \mathrm{bcd}$ & $49,94 \mathrm{bc}$ & $70,80 \mathrm{abcd}$ & $123,31 \mathrm{abc}$ & $16,48 \mathrm{bcd}$ & $19,97 \mathrm{bc}$ & $23,60 \mathrm{abcd}$ & $29,59 a b c$ \\
\hline T6 & 23,43 cde & $47,41 \mathrm{bc}$ & $54,85 \mathrm{bcd}$ & $100,16 a b c$ & 12,22 cde & $18,97 \mathrm{bc}$ & $18,28 \mathrm{bcd}$ & $24,04 a b c$ \\
\hline$T 7$ & $17,94 \mathrm{e}$ & $38,31 \mathrm{c}$ & $45,31 d$ & $83,73 \mathrm{c}$ & $9,36 \mathrm{e}$ & $15,33 \mathrm{c}$ & $15,10 d$ & $20,10 \mathrm{c}$ \\
\hline T8 & 22,62 de & $46,68 \mathrm{bc}$ & $61,32 \mathrm{abcd}$ & $108,96 a b c$ & $11,80 \mathrm{de}$ & 18,67 bc & $20,44 \mathrm{abcd}$ & $26,15 a b c$ \\
\hline T9 & $17,63 \mathrm{e}$ & $41,57 \mathrm{c}$ & $55,67 \mathrm{bcd}$ & $96,31 \mathrm{bc}$ & $9,20 \mathrm{e}$ & $16,63 \mathrm{c}$ & $18,56 \mathrm{bcd}$ & $23,11 \mathrm{bc}$ \\
\hline $\mathrm{T} 10$ & $30,02 \mathrm{bcd}$ & $53,68 a b c$ & $67,39 \mathrm{abcd}$ & $111,03 a b c$ & $15,66 \mathrm{bcd}$ & $21,47 a b c$ & $22,46 \mathrm{abcd}$ & $26,65 a b c$ \\
\hline $\mathrm{T} 11$ & $33,86 \mathrm{abcd}$ & $59,34 a b c$ & $73,01 \mathrm{abc}$ & $113,72 a b c$ & $17,67 \mathrm{abcd}$ & $23,74 a b c$ & $24,34 a b c$ & $27,29 a b c$ \\
\hline $\mathrm{T} 12$ & $23,03 \mathrm{de}$ & $39,71 \mathrm{c}$ & $50,46 \mathrm{~cd}$ & $88,91 \mathrm{c}$ & $12,01 \mathrm{de}$ & $15,89 \mathrm{c}$ & $16,82 \mathrm{~cd}$ & $21,34 \mathrm{c}$ \\
\hline $\mathrm{T} 13$ & $35,51 \mathrm{ab}$ & $65,55 a b$ & $79,79 a b$ & $136,50 \mathrm{ab}$ & $18,53 \mathrm{ab}$ & $26,22 \mathrm{ab}$ & $26,60 \mathrm{ab}$ & $32,76 a b$ \\
\hline T14 & $31,69 \mathrm{bcd}$ & $55,61 a b c$ & $66,35 \mathrm{abcd}$ & $108,72 a b c$ & $16,53 \mathrm{bcd}$ & $22,24 a b c$ & $22,12 \mathrm{abcd}$ & $26,09 a b c$ \\
\hline $\mathrm{T} 15$ & $33,36 \mathrm{bcd}$ & $59,56 a b c$ & $72,68 \mathrm{abc}$ & $124,48 a b c$ & $17,40 \mathrm{abcd}$ & $23,83 a b c$ & $24,22 a b c$ & $29,87 \mathrm{abc}$ \\
\hline $\mathrm{T} 16$ & $45,62 \mathrm{a}$ & $74,04 \mathrm{a}$ & $87,53 \mathrm{a}$ & $141,99 a$ & $23,80 \mathrm{a}$ & 29,62 a & 29,18 a & $34,08 \mathrm{a}$ \\
\hline $\mathrm{F}$ & $9,98^{* *}$ & 4,39 ** & $4.48^{\text {** }}$ & 3,18 * & $9,98^{* *}$ & 4,39 ** & $4,48^{* *}$ & 3,18 * \\
\hline D.M.S. & 11,2010 & 22,9000 & 26.3800 & 45,1440 & 3,7333 & 7,63337 & 8,7933 & 15,0480 \\
\hline C.V (\%) & 15,52 & 16,87 & 15,59 & 15,64 & 15,52 & 16,87 & 15,59 & 15,64 \\
\hline
\end{tabular}

1. Médias seguidas de mesma letra não diferem significativamente entre si pelo Teste de Tukey a de $1 \%$ de probabilidade; * nificativo pelo Teste $\mathrm{F}$ a $5 \%$ de probabilidade; ** Significativo pelo Teste $\mathrm{F}$ a de $1 \%$ de probabilidade. 
Tabela 12. Efeito dos períodos de convivência e de controle das plantas daninhas sobre a altura e D.A.P. de plantas de eucalipto. Brotas, SP.

\begin{tabular}{|c|c|c|c|c|c|c|c|c|c|c|c|c|}
\hline \multicolumn{13}{|c|}{ Meses após o plantio } \\
\hline \multirow[b]{2}{*}{ Trat. } & \multicolumn{3}{|c|}{ Altura (m) } & \multicolumn{3}{|c|}{ D.A.P. (cm) } & \multicolumn{3}{|c|}{ Volume $\left(\mathrm{m}^{3} \mathrm{ha}^{-1}\right)$} & \multicolumn{3}{|c|}{ I.M.A. $\left(\mathrm{m}^{3} \mathrm{ha}^{-1} \cdot \mathrm{ano}^{-1}\right)$} \\
\hline & 24 & 37 & 48 & 24 & 37 & 48 & 24 & 37 & 48 & 24 & 37 & 48 \\
\hline $\mathrm{T} 1$ & $9,48 \mathrm{ab}$ & $14,47 \mathrm{a}$ & $17,32 \mathrm{a}$ & $8,12 a b^{1}$ & $9,86 \mathrm{a}^{1}$ & $11,28 a^{1}$ & $24,22 a b$ & $58,31 a$ & $91,07 \mathrm{a}$ & $12,11 \mathrm{ab}$ & $18,91 \mathrm{a}$ & $22,77 \mathrm{a}$ \\
\hline $\mathrm{T} 2$ & $9,74 a b$ & $14,16 \mathrm{a}$ & 17,79 a & $8,64 \mathrm{a}$ & $10,43 \mathrm{a}$ & $11,85 \mathrm{a}$ & $25,25 a b$ & $56,00 \mathrm{a}$ & $89,60 \mathrm{a}$ & $12,63 a b$ & $18,16 \mathrm{a}$ & $22,40 \mathrm{a}$ \\
\hline T3 & $9,37 a b$ & $14,14 \mathrm{a}$ & $17,80 \mathrm{a}$ & $8,25 a b$ & $9,89 a$ & $11,67 \mathrm{a}$ & $28,49 a b$ & $67,39 a$ & $109,33 \mathrm{a}$ & $14,25 a b$ & $21,86 \mathrm{a}$ & $27,33 \mathrm{a}$ \\
\hline T4 & $9,92 \mathrm{a}$ & $14,44 \mathrm{a}$ & $18,16 \mathrm{a}$ & $9,03 \mathrm{a}$ & $11,01 \mathrm{a}$ & $12,60 \mathrm{a}$ & $33,73 \mathrm{a}$ & $76,00 \mathrm{a}$ & $126,63 \mathrm{a}$ & $16,87 \mathrm{a}$ & $24,65 \mathrm{a}$ & $31,66 \mathrm{a}$ \\
\hline T5 & $8,81 \mathrm{ab}$ & $13,31 \mathrm{a}$ & $16,62 \mathrm{a}$ & $7,85 a b$ & $9,64 \mathrm{a}$ & $10,90 \mathrm{a}$ & $23,53 a b$ & $55,18 \mathrm{a}$ & $87,54 \mathrm{a}$ & $11,76 a b$ & $17,90 \mathrm{a}$ & $21,89 a$ \\
\hline T6 & $9,42 a b$ & $14,24 \mathrm{a}$ & $18,06 \mathrm{a}$ & $8,35 a b$ & $10,54 \mathrm{a}$ & $12,19 \mathrm{a}$ & $24,89 a b$ & $62,76 \mathrm{a}$ & $107,55 \mathrm{a}$ & $12,44 a b$ & $20,35 a$ & $26,89 a$ \\
\hline $\mathrm{T} 7$ & $9,25 a b$ & $14,49 a$ & $17,91 \mathrm{a}$ & 8,33ab & $10,37 \mathrm{a}$ & $11,81 \mathrm{a}$ & $24,48 a b$ & $62,20 \mathrm{a}$ & $100,72 \mathrm{a}$ & $12,24 a b$ & $20,17 \mathrm{a}$ & $25,18 a$ \\
\hline T8 & $8,26 a b$ & $13,07 \mathrm{a}$ & $16,97 \mathrm{a}$ & $7,11 b$ & $8,78 a$ & $10,85 a$ & $14,99 \mathrm{~b}$ & 37,27 a & 70,35 a & $7,50 \mathrm{~b}$ & $12,09 \mathrm{a}$ & $17,59 a$ \\
\hline T9 & $8,76 a b$ & $13,60 \mathrm{a}$ & $17,04 \mathrm{a}$ & $7,70 a b$ & $9,84 \mathrm{a}$ & $11,11 \mathrm{a}$ & $22,41 a b$ & $58,12 \mathrm{a}$ & $94,23 \mathrm{a}$ & $11,21 a b$ & $18,85 \mathrm{a}$ & $23,56 \mathrm{a}$ \\
\hline T10 & $7,29 b$ & $11,85 a$ & $16,02 \mathrm{a}$ & $6,03 b$ & $8,35 a$ & $10,00 \mathrm{a}$ & $14,13 b$ & $41,44 \mathrm{a}$ & $70,21 a$ & $7,07 \mathrm{~b}$ & $18,44 \mathrm{a}$ & $17,55 \mathrm{a}$ \\
\hline $\mathrm{T} 11$ & $9,36 a b$ & $14,31 \mathrm{a}$ & $18,10 \mathrm{a}$ & $8,03 a b$ & $10,71 \mathrm{a}$ & $12,17 \mathrm{a}$ & $23,82 a b$ & $65,32 \mathrm{a}$ & $98,62 \mathrm{a}$ & $11,91 a b$ & $21,19 a$ & $24,65 \mathrm{a}$ \\
\hline T12 & $9,26 a b$ & $14,34 \mathrm{a}$ & $17,43 \mathrm{a}$ & $8,19 a b$ & $10,55 \mathrm{a}$ & $11,80 \mathrm{a}$ & $22,72 a b$ & $59,20 \mathrm{a}$ & 90,68 a & $11,36 a b$ & $19,20 \mathrm{a}$ & $22,67 \mathrm{a}$ \\
\hline T13 & $9,74 a b$ & $14,55 \mathrm{a}$ & $18,08 \mathrm{a}$ & $8,80 a$ & $10,86 a$ & $11,60 \mathrm{a}$ & $29,69 a b$ & $69,21 \mathrm{a}$ & $105,42 \mathrm{a}$ & $14,85 a b$ & $22,45 \mathrm{a}$ & $26,36 \mathrm{a}$ \\
\hline $\mathrm{T} 14$ & $9,29 a b$ & $14,23 \mathrm{a}$ & $17,63 \mathrm{a}$ & $8,48 a b$ & 10,69 a & $11,76 \mathrm{a}$ & $24,91 a b$ & $63,43 \mathrm{a}$ & 96,75 a & $12,45 a b$ & $20,57 \mathrm{a}$ & $24,19 a$ \\
\hline T15 & $9,46 a b$ & $14,15 a$ & $17,43 a$ & $8,35 a b$ & $10,44 a$ & $12,00 \mathrm{a}$ & $24,75 a b$ & $59,75 a$ & $96,92 \mathrm{a}$ & $12,37 a b$ & $19,38 \mathrm{a}$ & $24,23 \mathrm{a}$ \\
\hline T16 & $9,74 a b$ & $14,30 \mathrm{a}$ & $17,79 a$ & $8,12 \mathrm{a}$ & $10,14 \mathrm{a}$ & $11,74 \mathrm{a}$ & $26,25 a b$ & $55,23 \mathrm{a}$ & $91,91 \mathrm{a}$ & $13,12 a b$ & $17,91 \mathrm{a}$ & $22,98 \mathrm{a}$ \\
\hline$F$ & 1,67 * & 1,26 NS & $0,57 \mathrm{NS}$ & $2,17^{*}$ & $1,09 \mathrm{NS}$ & $1,02 \mathrm{NS}$ & 1,74 * & $0,96 \mathrm{NS}$ & $1,13 \mathrm{NS}$ & 1,74 * & $0,96 \mathrm{NS}$ & $1,13 \mathrm{NS}$ \\
\hline D.M.S. & 2,6109 & 3,23 & 4,07 & 2,5099 & 3,565 & 3,20 & 18,404 & 49,75 & 66,59 & 18,40 & 49,75 & 66,59 \\
\hline C.V (\%) & 11,11 & 9,04 & 9,10 & 12,09 & 13,77 & 10,81 & 29,69 & 32,91 & 27,30 & 29,69 & 32,91 & 27,30 \\
\hline
\end{tabular}

1. Médias seguidas de mesma letra não diferem significativamente entre si pelo Teste de Tukey a de $1 \%$ de probabilidade; * Significativo pelo Teste $5 \%$ de probabilidade; ** Significativo pelo Teste $\mathrm{F}$ a de $1 \%$ de probabilidade. 


\section{PERÍODOS DE CONTROLE DE Brachiaria sp E SEUS REFLEXOS NA PRODUTIVIDADE DO EUCALIPTO}

\section{Resumo}

Com o objetivo de estudar os efeitos dos períodos de controle de Brachiaria sp sobre a produtividade de plantas de Eucalyptus grandis W. Hill ex Maiden foi conduzido um ensaio localizado no município de Piratininga, SP, no período de agosto de 1991 a maio de 1999. Os tratamentos consistiram de diferentes períodos de convivência e de controle das plantas daninhas na cultura do eucalipto divididos em dois grupos. No primeiro, a convivência iniciava no plantio e era estendida até $28,56,84,112,140,168,278$ e 360 dias. No segundo, a convivência iniciava aos $0,28,56,84,112,140,168$ e 278 dias e era estendida até 364 dias. As populações mais freqüentes que ocorreram na área experimental foram Bracharia decumbens e Brachiaria brizantha Aos 12 meses após o plantio as plantas de eucalipto foram bastante susceptíveis à int erferência das plantas daninhas apresentando um período anterior à interferência (P.A.I.) inferior a 6 e 12 dias, considerando-se 2 e $5 \%$ de redução em altura. Já o período total de prevenção àinterferência (PTPI) em relação a altura foi de 364 e 356 dias aos 12 meses, 194 e 166 dias aos 24 meses, 188 e 130 dias aos 36 meses, 88 e 54 dias aos 48 meses e 155 e 133 dias aos 78 meses. Quando se analisa o D.A.P. o PTPI foi de 242 e 200 dias aos 24 meses, 208 e 153 dias aos 36 meses, 224 e 150 dias aos 48 meses e 134 e 119 dias aos 78 meses. No entanto, quando se analisa o volume de madeira $\left(\mathrm{m}^{3} \mathrm{ha}^{-1}\right)$ o PTPI foi de 153 e 142 dias aos 36 meses, 99 e 91 dias aos 48 meses e 92 e 79 dias aos 78 meses após o plantio (colheita da cultura), o que demonstra a recuperação das plantas de eucalipto àinterferência das plantas daninhas e o deslocamento do PTPI com a idade e parâmetro da 
cultura avaliado.

PALAVRAS CHAVE: Eucalipto, competição, manejo de plantas daninhas e interferência.

\section{Brachiaria sp CONTROL PERIODS AND ITS EFFECTS AT THE PRODUCTIVITY OF EUCALYPTUS}

\section{Summary}

This research has been carried out in Piratininga, São Paulo State, Brazil, from August to 1991 through May 1999, with the goal of a studying about the effects of the weed interference at the Eucalyptus grandis W. Hill Ex Maiden productivity. The experimental design has been completed taking some blocks at random in four reaplications. The treatments have consisted of different extensions and the different time limits of the weed control periods. The weed control periods have been divided into two groups. At the first one, the weed control periods have been since the Eucalyptus plantation to 28, 56, 112, 140, 168, 224, 278 and 360 days. At the second group the weed control period has begun at $0,28,56,112,140,168,224$ and 278 days after the plantation and has finished at the end of the 364 days. The main weeds have been Brachiaria decumbens and Brachiaria brizantha. The Eucalyptus plants have been strong, susceptive at the weed interference throughout 12 months the after plantation, it has been shown at PAI of 12 and 6 days, when it has been considered a reduction of 2 and $5 \%$ of the height. Although, to assure the crop productivity in Piratininga it was necessary to keep a weed control period in a range of 364 and 365 days after plantation (PTPI) throughout 12 months, 194 and 166 days after plantation throughout 24 months, 188 and 130 days after plantation throughout 36 months, 88 and 54 days after plantation throughout 48 months and 155 and 133 days after plantantion throught 78 months, when it has been considered a reduction of 2 and $5 \%$ of the heigth. But, if when it has been 
considered the D.A.P., the PTPI has been 242 and 200 days after plantation throughout 24 months, 208 and 153 days after plantation 36 months, 224 and 150 days after plantation throughout 48 months and 134 and 119 days after plantantation throughtout 78 months. Although in that case it should consider the wood volume it has been necessary to keep the weed control away from the plant in a range of 153 and 142 days throughout 36 months after plantation, 99 and 91 days throughout 48 months after plantation and 92 and 72 days throughout 78 months after plantation (crop). It has shown na improvement at the quality in the Eucalyptus plants when these have been the weed interference.

KEY WORDS: Eucalyptus, competition, weed management and interference.

\subsection{Introdução}

O Brasil ocupa o quarto lugar no mundo em implantação de maciços florestais homogêneos, sendo a sua base florestal representada por seis milhões de hectares reflorestados, com incrementos anuais em torno de 400 mil hectares (Brito, 1995).

As culturas florestais, como outras, estão sujeitas a interferência das plantas daninhas, que reflete em decréscimos quali-quantitativos em sua produção. A Interferência das plantas daninhas com a cultura deve-se principalmente a competição por recursos do meio que são essenciais ao crescimento. Para sobreviverem, os competidores disputam a luz solar, os nutrientes e a água, sendo mais crítico o período dos dois primeiros anos de instalação da cultura do eucalipto (Donald, 1963; Pitelli et al., 1988; Rodrigues et al., 1991; Pitelli \& Marchi, 1991; Marchi, 1996; Bezutte et al., 1995; Toledo, 1998 e Toledo et al., 2000). Porém essas pesquisas consideram apenas os efeitos dos períodos de controle e de convivência sobre o desenvolvimento inicial das plantas de eucalipto e não os efeitos desses períodos e os reflexos da interferência das plantas daninhas no 
desenvolvimento inicial das plantas sobre a produtividade e qualidade final da madeira para celulose e papel.

É importante ressaltar que o setor florestal tem se expandido em áreas de cerrado, as quais eram anteriormente ocupadas por pastagens, especialmente de Brachiaria decumbens. Assim, essa planta, devido a sua elevada agressividade e difícil controle, tornou-se uma das infestantes mais problemáticas nos plantios comerciais de Eucalyptus sp (Toledo et al., 1996).

O manejo das plantas daninhas em áreas florestais, nas diversas etapas do seu processo produtivo, é realizado, basicamente, pelo emprego de métodos mecânicos e químicos, isolados ou combinados. Para que este manejo seja eficaz se faz necessário determinar o período, a partir do plantio, em que a cultura pode conviver com a comunidade infestante antes que seu crescimento e produção sejam afetados, e o período em que a cultura deve ser mantida sem a presença das plantas daninhas, de modo a assegurar pleno potencial de crescimento e de produção e o período em que as plantas infestantes que emergirem após, não mais concorram com a cultura do eucalipto. (Toledo, 1998).

Neste contexto, esta pesquisa teve por objetivo estudar os efeitos dos períodos de controle de Brachiaria sp sobre a produtividade de Eucalyptus grandis W. Hill Ex Maiden no município de Piratininga, SP.

\subsection{Material e Métodos}

A pesquisa foi conduzida em uma área florestal pertencente a Votorantim Celulose e Papel S.A., localizada no município Piratininga, SP, no período de agosto de 1991 a maio de 1999.

A área experimental foi selecionada quanto à uniformidade na infestação de plantas daninhas, sendo esta representativa das áreas de produção da empresa florestal. A área localizada em Piratininga, SP era de reforma de eucalipto. Em levantamento prévio, pela técnica de amostragens aleatórias, foi 
constatado que as populações mais freqüentes foram o capim-braquiária (Brachiaria decumbens Stapf), o capim-braquiarão (Brachiaria brizantha (Hoestch.) Stapf), a erva-quente (Spermacocea latifola Aubl.), as guanxumas (Sida spp.), a malva-vermelha (Croton spp.) e algumas rebrotas de cerrado.

Após a seleção, a área foi homogeneizada quanto à distribuição e ao estádio de desenvolvimento da comunidade infestante. Para tanto, foi necessária a incorporação da biomassa verde da comunidade infestante presente na área experimental com gradagem leve e procedida a passagem de uma gradagem dupla com máquina pesada em área total. Em seguida, foram realizadas: a abertura das covas com enxadões e a adubação de plantio, que constituiu da distribuição de $500 \mathrm{~kg} \cdot \mathrm{ha}^{-1}$ de FAPS.

As mudas de eucalipto, com cerca de 100 dias de idade e provenientes de sementes obtidas junto ao viveiro da Votorantim Celulose e Papel, foram plantadas no espaçamento de 2,0 m entre plantas e 3,0 m entrelinhas de plantio.

As parcelas experimentais foram constituídas por seis linhas de plantio com seis plantas cada, totalizando $288 \mathrm{~m}^{2}$, sendo duas linhas externas de cada lado e duas plantas nas extremidades das linhas internas consideradas bordadura, totalizando $24 \mathrm{~m}^{2}$ de área útil.

Os tratamentos experimentais foram divididos em dois grupos. No primeiro, as plantas de eucalipto conviveram com a comunidade infestante por períodos crescentes desde o plantio. Após o término de cada período, a cultura foi mantida no limpo até o final do primeiro ano (364 dias). Os períodos estudados foram: $0,28,56,84,112,140,168,278$ e 360 dias a partir do plantio, conforme descritos na Tabela 13. No segundo grupo, as plantas daninhas foram controladas por períodos crescentes na cultura do eucalipto, desde o plantio. Ao final de cada período as plantas daninhas que emergiram foram deixadas crescer livremente. Os períodos estudados neste grupo foram idênticos ao grupo anterior (Tabela 13).

No campo, os tratamentos foram dispostos no delineamento de blocos ao acaso, com quatro repetições. Os dados obtidos foram submetidos pelo teste $F$ 
aplicado àanálise de variância, e as médias individuais confrontadas pelo teste de comparação múltipla de Tukey a $5 \%$ de probabilidade. Para a determinação dos períodos de interferência, os dados de diâmetro do caule, diâmetro medido a altura do peito (D.A.P.), altura, volume médio e incremento médio anual de madeira (I.M.A.) das plantas de eucalipto foram submetidos à análise de regressão e graficamente representados, segundo o modelo sigmoidal de Boltzmann, adaptado por Toledo (1998), sendo a equação geral: $\mathbf{Y}=\left(\mathbf{A}_{1}-\mathbf{A}_{2}\right) /\left\{\mathbf{1}+\exp \left[\left(\mathbf{x}-\mathbf{x}_{0}\right) / \mathbf{d x}\right]\right\}+\mathbf{A}_{2}$. (Figura 7). Os limites dos períodos de interferência foram determinados tolerandose perdas máximas de produção de 2 e 5 \% em relação àquela obtida nas parcelas mantidas no limpo durante o primeiro ano de ciclo da cultura.

Tabela 13. Descrição dos tratamentos experimentais. Piratininga, SP.

\begin{tabular}{ccc}
\hline TRATAMENTOS & \multicolumn{2}{c}{ PERÍODOS INICIAIS } \\
\hline 1. & 0 SEM CONTROLE & COM CONTROLE \\
\hline 2. & $0-28$ & $0-360$ \\
3. & $0-56$ & $28-360$ \\
4. & $0-84$ & $56-360$ \\
5. & $0-112$ & $84-360$ \\
6. & $0-140$ & $112-360$ \\
7. & $0-168$ & $140-360$ \\
8. & $0-278$ & $168-360$ \\
9. & $0-360$ & $278-360$ \\
10. & $28-360$ & 0 \\
11. & $56-360$ & $0-28$ \\
12. & $84-360$ & $0-56$ \\
13. & $112-360$ & $0-84$ \\
14. & $140-360$ & $0-112$ \\
15. & $168-360$ & $0-140$ \\
16. & $278-360$ & $0-168$ \\
\hline
\end{tabular}

* Em número de dias após o plantio. 


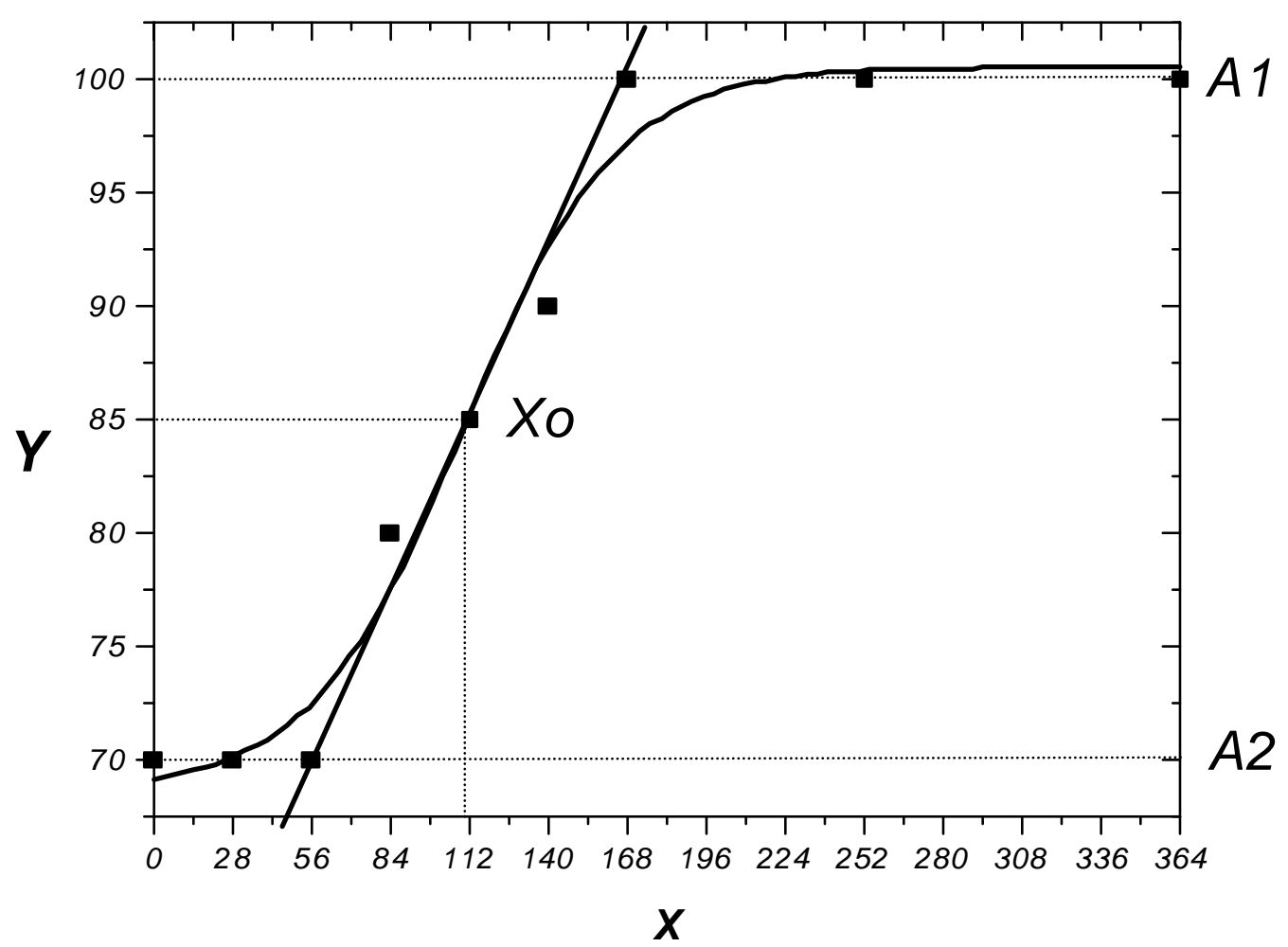

controle ou convivência

$$
Y=\frac{\left(A_{1}-A_{2}\right)}{1+e^{\left(X-X_{0}\right) / d X}}+A_{2}
$$

Figura 7 - Representação gráfica e matemática do modelo sigmoidal de Boltzman utilizado no ajuste dos dados de D.A.P., altura, volume de madeira e I.M.A. das plantas de eucalipto sob diferentes períodos de controle das plantas daninhas. Onde:

$\mathrm{Y} \quad=$ produção das plantas de eucalipto em função dos períodos de controle ou de convivência.

$\boldsymbol{X} \quad=$ limite superior do período de controle ou de convivência.

$\boldsymbol{A}_{1}=$ produção máxima obtida nas parcelas mantidas no limpo durante 0 desenvolvimento das plantas de eucalipto.

$\boldsymbol{A}_{2} \quad$ = produção mínima obtida nas parcelas mantidas no limpo durante o desenvolvimento das plantas de eucalipto. 
$\left(\boldsymbol{A}_{1}-\boldsymbol{A}_{2}\right)$ = perda de produção.

$\boldsymbol{X}_{\boldsymbol{0}} \quad=$ limite superior do período de controle ou de convivência, que corresponde ao valor intermediário entre a produção máxima e mínima.

DX = parâmetro que indica velocidade de perda ou ganho de produção (tg á no ponto $\mathrm{X}_{0}$ ).

Para a limpeza das parcelas ao término de cada período experimental e a sua manutenção desta forma, até o período experimental, foram realizadas capinas manuais seguidas da aplicação de $0,72 \mathrm{~kg}$ i.a. de oxyfluorfen.ha ${ }^{-1}$, efetuadas em área total com pulverizador costal, utilizando-se bicos 110.02, regulado para um consumo de calda de 300 L.ha $^{-1}$.

Aos 12, 24, 36, 48 e 78 meses após o plantio das mudas, as oito plantas úteis de eucalipto foram avaliadas quanto àaltura. Aos 24, 36, 48 e 78 meses após o plantio foram avaliados: o diâmetro do caule medido a altura do peito (DAP), volume $\left(\mathrm{m}^{3} \mathrm{ha}^{-1}\right)$ e incremento médio de madeira - IMA - $\left(\mathrm{m}^{3} \mathrm{ha}^{-1} \cdot \mathrm{ano}^{-1}\right)$.

$\mathrm{Na}$ área útil de cada parcela experimental foi amostrado $1,5 \mathrm{~m}^{2} \mathrm{da}$ comunidade infestante, correspondendo a seis amostras de $0,25 \mathrm{~m}^{2}$, das quais três amostras foram amostradas na linha e três na entre linha de plantio do eucalipto. As espécies de plantas daninhas presentes nas amostras foram identificadas, contadas e levadas ao Laboratório do Departamento de Biologia Aplicada à Agropecuária da Faculdade de Ciências Agrárias e Veterinárias de Jaboticabal, UNESP, onde foram lavadas e secas em estufa com renovação de ar a $70{ }^{\circ} \mathrm{C}$ por 96 horas. Após este procedimento, foi determinada a biomassa seca da parte aérea das plantas coletadas, utilizando balança eletrônica com precisão de 0,01 grama.

\subsection{Resultados e Discussão}

As populações mais freqüentes na área de Piratininga, SP foram o capimbraquiária (Brachiaria decumbens Stapf), o capim-braquiarão (Brachiaria brizantha (Hoestch.) Stapf), a erva-quente (Spermacocea latifola Aubl.), as 
guanxumas (Sida spp.), a malva-vermelha (Cróton spp.) e algumas dicotiledôneas e rebrotas de cerrado, conforme pode ser observado na Tabela 14.

Tabela 14. Plantas daninhas mais comuns que ocorreram na área de Piratininga, SP.

\begin{tabular}{llcc}
\hline \multicolumn{1}{c}{ Nome comum } & \multicolumn{1}{c}{ Nome científico } & Família & Código \\
\hline Capim-braquiária & (1) Brachiaria decumbens Stapf & Poaceae & BRADC \\
Capim-braquiarião & (1) Brachiaria brizantha (Hoestch.) Stapf & Poaceae & BRABR \\
Guanxumas & (2) Sidas spp. & Malvaceae & ----- \\
Erva-quente & (2) Spermacocea latifola Aubl. & Rubiaceae & BOILF \\
Poaia-do-campo & (2) Richardia brasiliensis Gómez & Rubiaceae & RCHBR \\
Picão-preto & (2) Bidens pilosa L. & Amaranthaceae & BIDPI \\
Carrapicho-rasteiro & (2) Acanthospermum australe (Loefl) Kuntze & Amaranthaceae & ACANAU \\
Mentrasto & (2) Ageratum conyzoides L. & Amaranthacea & AGECO \\
Beldroega & (2) Portulaca oleraceae L. & Portulacaceae & POROL \\
Malva-vermelha & (2) Croton glandulosus L. & Euphorbiaceae & CVNGL \\
Rebrotas de Cerrado & (2) NÃO IDENTIFICADAS & Não identificadas & ----- \\
\hline
\end{tabular}

(1) -Monocotiledôneas; (2)- Dicotiledôneas.

Dentre estas populações de plantas daninhas as monocotiledôneas acumularam 913,3 g.m $\mathrm{m}^{-2}$ da biomassa seca na área total da parcela testemunha "no mato", ou seja, nas parcelas nas quais as plantas de eucalipto conviveram com a comunidade infestante por 364 dias após o plantio. Já nas parcelas nas quais a cultura do eucalipto conviveu com a comunidade infestante por 278 dias após o plantio, as monocotiledôneas acumularam $1181,7 \mathrm{~g} \cdot \mathrm{m}^{-2}$ da biomassa seca, enquanto as dicotiledôneas acumularam $29,3 \mathrm{~g} \cdot \mathrm{m}^{-2}$, o infere que os efeitos da interferência das monocotiledôneas sobre a produtividade da cultura do eucalipto na área de Piratininga, SP foi mais severo (Figura 8). 


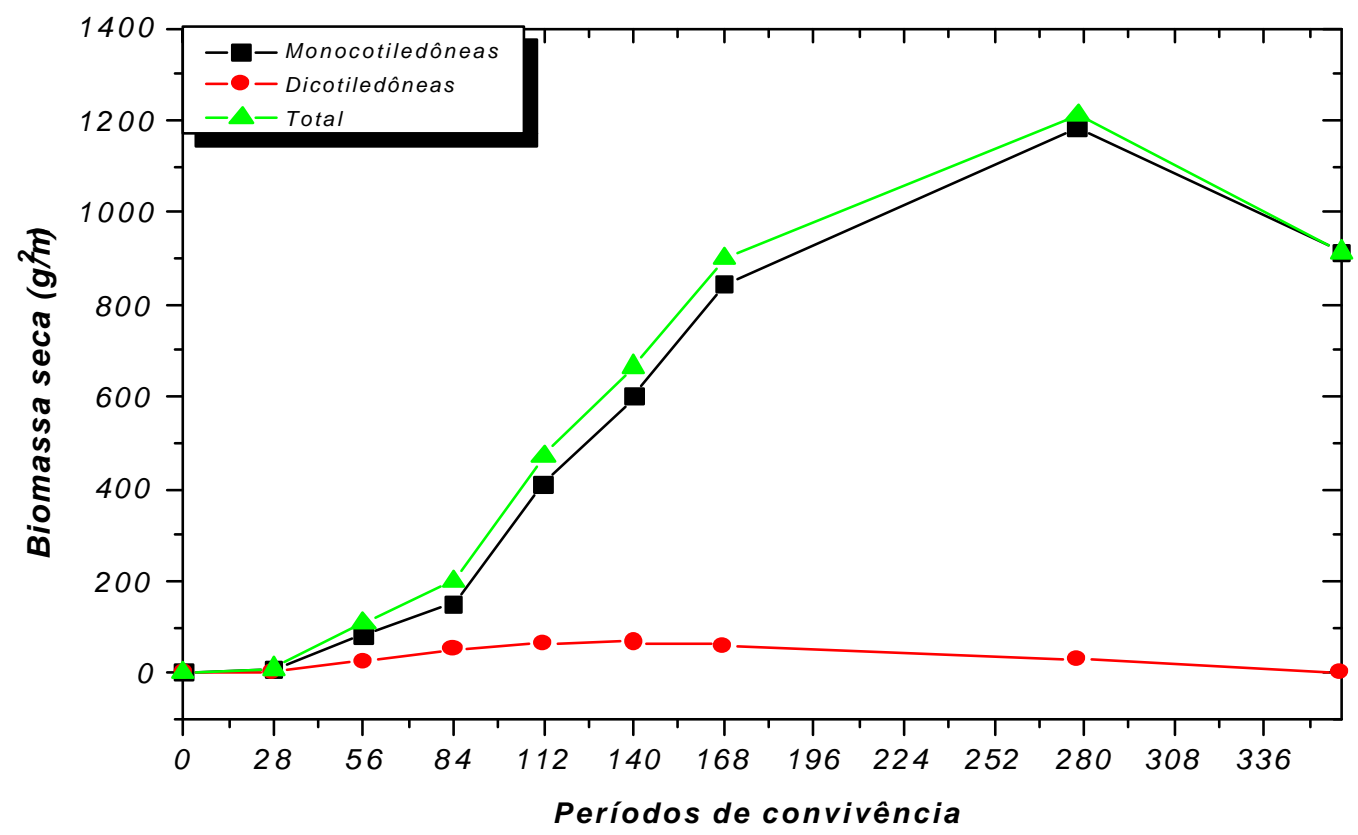

Figura 8 - Biomassa média seca acumulada $\left(\mathrm{g} \cdot \mathrm{m}^{-2}\right)$ das principais espécies de plantas daninhas presentes nas parcelas nas quais as plantas de eucalipto conviveram com a comunidade infestante por 364 dias após 0 plantio.

Toledo et al., (2000) observou que o capim-braquiária foi a população predominante em Três Lagoas, MS, acumulando em média 1556,1 g.m $\mathrm{m}^{-2}$ da biomassa seca na área total da parcela da testemunha "no mato". Nesta área, as plantas de eucalipto que conviveram com a comunidade infestante durante os primeiros 364 dias, apresentaram diâmetro médio de $2,1 \mathrm{~cm}$ e altura de $1,6 \mathrm{~m}$, o que representaram 68,2\% e 65,7\% de redução em relação à plantas de eucalipto que cresceram livres da interferência das plantas daninhas que apresentaram diâmetro e altura de 6,7 cm e 4,7 m, respectivamente. Essas diferenças foram devido à alta pressão de interferência exercida pelas plantas daninhas, especialmente o capim-braquiária. 
O período a partir do plantio da cultura no qual as plantas daninhas devem ser controladas para que o desenvolvimento inicial do eucalipto não seja afetado significativamente denominado por Pitelli \& Durigan (1984) de período total de prevenção àinterferência (PTPI) observado nesta pesquisa foi de 364 e 356 dias, quando se considera a redução de $2 \%$ e $5 \%$ em altura das plantas de eucalipto aos 12 meses após o plantio, respectivamente. Já o período anterior a interferência (PAI) foi de 6 e 12 dias, quando se considera a altura das plantas de eucalipto, respectivamente (Tabela 15).

Já o período crítico de prevenção à interferência (PCPI) obtido na área de Piratininga, SP aos 12 meses foi de 6 a 364 dias e 12 a 356 dias, quando se considera a redução de $2 \%$ e $5 \%$ na altura das plantas de eucalipto. No entanto, o PTPI observado por Toledo et al., (2000) no município de Três Lagoas, MS foi de 140 dias, quando se considera redução de $5 \%$ de diâmetro do caule e altura das plantas de eucalipto. Já o PAl foi de 14 e 28 dias, quando se considera o diâmetro do caule e a altura, respectivamente, sendo o PCPI de 14-28 a 140 dias, quando se considera o diâmetro do caule e a altura das plantas, respectivamente.

Aos 12 meses, as plantas de eucalipto que conviveram com a comunidade infestante por 364 dias (testemunha "no mato") em Piratininga, SP, apresentaram altura média de 1,2 m enquanto as plantas que cresceram livres da presença das plantas daninhas (testemunha "no limpo") apresentaram 3,3 m, o que representa $65,1 \%$ de redução demonstrando a interferência severa das plantas daninhas sob a altura das plantas de eucalipto no primeiro ano de desenvolvimento da cultura (Tabela 16). Esta resposta em relação àaltura do eucalipto não era esperada, uma vez que a altura não constitui característica adequada para avaliação dos dados de competição (Rodrigues et al., 1991).

Desse modo, Pitelli \& Marchi (1991) comentam que sob intensa infestação de plantas daninhas o eucalipto tende a perder rapidamente os ramos e as folhas da base da copa, apresentando, com isso, pequena quantidade de folhas concentradas m topo da planta, provocando o estiolamento da muda, devido à 
interceptação de luz que restringe a fonte predominante de energia aos processos básicos de recrutamento de elementos e de elaboração de todas as substâncias envolvidas no crescimento vegetal.

$\mathrm{Na}$ Tabela 16, pode-se observar aos 24,36 e 48 meses que os valores de PTPI obtidos foram de 194 e 166 dias, 188 e 130 dias e 88 e 54 dias, quando se considera a redução de $2 \%$ e $5 \%$ em altura das plantas de eucalipto, respectivamente, e de 242 e 200 dias, 208 e 153 dias e de 224 e 119 dias, quando se considera a redução de $2 \%$ e $5 \%$ em diâmetro do caule das plantas de eucalipto, respectivamente. No entanto, os valores de PAl observados aos 24 meses foram de 98 e 114 dias e de 95 e 114 dias, quando se considera a redução de $2 \%$ e $5 \%$ em altura e D.A.P. das plantas de eucalipto, respectivamente. Aos 36 meses após o plantio o PAl foi de 69 e 109 dias, quando se considera a redução em altura. Já a partir dos 48 meses não foram observados valores de PAl em relação àal tura e o D.A.P. das plantas de eucalipto.

Portanto, os períodos críticos de prevenção àinterferência (PCPI) obtidos na área de Piratininga, SP aos 24 meses foram 98 a 194 dias e 114 a 166 dias e de 95 a 242 dias e 114 a 200 dias, quando se considera a redução de $2 \%$ e 5\% na altura e no D.A.P. das plantas de eucalipto, respectivamente. Já aos 36 meses, o PCPI observado foi de 69 a 188 dias e 109 a 130 dias, quando se considera a altura das plantas de eucalipto, respectivamente.

Aos 24, 36 e 48 meses, as plantas de eucalipto da testemunha "no mato" apresentaram 6,8, 10,3 e 15,6 m de altura e 6,3, 9,3 e 12,1 cm de D.A.P., respectivamente, enquanto as plantas de eucalipto da testemunha "no limpo" apresentaram 10,9, 15,3 e 18,6 m de altura e 10,3, 13,3 e 14,5 cm de diâmetro do caule, respectivamente, o que representa 37,6, 32,7 e 15,8\% de redução em altura e 38,4, 30,6 e 16,2\% de redução em D.A.P., sugerindo a tendência de recuperação das plantas de eucalipto a interferência imposta pela comunidade infestante (Tabela 17). 
Aos 78 meses após o plantio desta área, ou seja, por ocasião da colheita das plantas de eucalipto o PTPI foi de 155 e 133 dias e 134 e 119 dias, quando se considera a redução de $2 \%$ e $5 \%$ em altura e D.A.P. das plantas de eucalipto, respectivamente (Tabela 16).

As plantas de eucalipto que cresceram nas parcelas da testemunha "no mato" apresentaram 21,67 m de altura e $13,74 \mathrm{~cm}$ de D.A.P., enquanto as plantas de eucalipto que cresceram na testemunha "no limpo" apresentaram altura média de 26,6 m e D.A.P. médio de $16,1 \mathrm{~cm}$, o que representam $18,4 \%$ e $14,5 \%$ de redução, respectivamente, sugerindo mais uma vez a tendência de recuperação das plantas de eucalipto a essa interferência (Tabela 17).

De acordo com Gonçalves et al., (2000) nos três primeiros meses de crescimento das mudas de eucalipto no campo as taxas de absorção de nutrientes são pequenas. Neste período, as mudas de eucalipto alocam grande quantidade de fotoassimilados e nutrientes para a síntese de raízes para assegurar o suprimento de água e nutrientes. Por este motivo, se desenvolvem menos, e podem mostrar sintomas de deficiências nutricionais.

Posteriormente, com os suprimentos de água e nutrientes assegurados, a atividade fotossintética é intensificada, havendo grande expansão da área foliar e maior crescimento epígeo das mudas de eucalipto. A seguir ocorre uma fase de intenso crescimento e acúmulo de nutrientes, com elevadas taxas de absorção que se relacionam diretamente com a idade da cultura. Neste período, as plantas de eucalipto estão mais sensíveis a competição das plantas daninhas, pois todos os fotoassimilados são sintetizados para a formação de copas (expansão da área foliar) e sistema radicular, principalmente raízes finas (raízes com função de absorção de água e nutrientes). O sistema radicular explora parcialmente o volume do solo e as árvores não competem entre si por fatores de crescimento (luz, nutrientes, espaço e água), sendo seu crescimento limitado pelas próprias condições fisiológicas e pelos inimigos naturais, incluindo as plantas daninhas (Gonçalves et al., 2000). 
A intensa resposta àfertilização neste estágio de desenvolvimento é muito comum. Nestas situações, as taxas de absorção de nutrientes e a atividade metabólica dos componentes das árvores são elevadas, podendo ser aumentados o tempo de retenção das folhas e a eficiência fotossintética por unidade de área foliar (Gonçalves et al., 2000).

Sob baixas disponibilidades de água e nutrientes, as plantas daninhas podem competir com as plantas de eucalipto, podendo gerar deficiências principalmente na fase de estabelecimento das florestas. Uma das razões do grande poder competitivo dessas plantas daninhas está relacionada a grande capacidade de adaptação das populações infestantes às condições ambientais do sítio (Silva et al., 1997). Portanto, pode-se justificar o efeito mais severo das plantas daninhas nas fases iniciais de desenvolvimento do eucalipto.

$\mathrm{Na}$ Tabela 16, pode-se observar aos 36 e 48 meses que os valores de PTPI obtidos foram de 153 e 142 dias e 99 e 91 dias, quando se considera a redução de $2 \%$ e $5 \%$ no volume médio de madeira das plantas de eucalipto, respectivamente, e de 155 e 140 dias e 94 e 85 dias, quando se considera a redução de $2 \%$ e $5 \%$ no incremento médio anual de madeira (I.M.A.) das plantas de eucalipto, respectivamente.

Aos 36 e 48 meses, as plantas de eucalipto da testemunha "no mato" apresentaram 36,3 e $84,5 \mathrm{~m}^{3} \cdot \mathrm{ha}^{-1}$ de volume médio de madeira e 11,7 e 20,6 $\mathrm{m}^{3}$.ha ${ }^{-1}$.ano ${ }^{-1}$ de I.M.A., respectivamente, enquanto as plantas de eucalipto da testemunha "no limpo" apresentaram 142,2 e 220,0 $\mathrm{m}^{3}$.ha ${ }^{-1}$ de volume médio de madeira e 45,9 e $53,7 \mathrm{~m}^{3}$.ha ${ }^{-1}$.ano ${ }^{-1}$ de I.M.A., respectivamente, o que representa $74,5 \%$ e $61,6 \%$ de redução em volume médio de madeira e $74,4 \%$ e $61,5 \%$ de redução em D.A.P., demonstrando o forte efeito da interferência das plantas daninhas sobre a estimativa da produtividade da cultura do eucalipto (Tabela 17).

Já aos 78 meses o PTPI foi de 92 e 78 dias, quando se considera a redução de $2 \%$ e $5 \%$ no volume médio de madeira e 90 e 78 dias, quando se considera o I.M.A. de madeira das plantas de eucalipto (Tabela 16), sugerindo 0 
deslocamento do PTPI em função do tempo e conseqüente recuperação das plantas de eucalipto a interferência das plantas daninhas. Na colheita da cultura, as plantas de eucalipto que cresceram nas parcelas da testemunha "no mato" apresentaram 212,3 $\mathrm{m}^{3}$.ha ${ }^{-1}$ de volume de madeira e $32,7 \mathrm{~m}^{3}$.ha ${ }^{-1}$.ano ${ }^{-1}$ de I.M.A., enquanto as plantas de eucalipto que cresceram na testemunha "no limpo" apresentaram volume médio de madeira de $371,2 \mathrm{~m}^{3}$.ha ${ }^{-1}$ e I.M.A. médio de 57,1 $\mathrm{m}^{3}$.ha ${ }^{-1}$.ano ${ }^{-1}$, o que representam $42,8 \%$ e $42,8 \%$ de redução, respectivamente, sugerindo mais uma vez a tendência de recuperação das plantas de eucalipto a essa interferência (Tabela 17).

De modo geral, poder-se-ia dizer que, quanto maior for o período de convivência entre a cultura do eucalipto e a comunidade infestante, maior seria o grau de interferência. No entanto, segundo Pitelli (1987), isto não é totalmente válido, porque dependerá da época do ciclo da cultura em que este período for considerado, o que pode ser observado pelos resultados obtidos por Marchi (1996), Toledo et al., (2000) e na presente pesquisa.

Os períodos encontrados por diferentes autores como Pitelli et al., (1988), Rodrigues et al., (1991), Marchi (1996) e Toledo et al., (2000) não são idênticos. Isto pode ser explicado pelo fato das condições de condução dessas pesquisas, as próprias espécies florestais ou clones utilizados e as composições específicas das comunidades infestantes serem distintas e que dada a esta diversidade tornase fundamental que estas pesquisas se intensifiquem e ultrapassem os limites das Universidades, sendo executadas com convênios com as empresas florestais que visam obter informações mais significativas para as suas áreas de produção.

Marchi (1996) observou que os maiores ganhos de crescimento da cultura do eucalipto foram obtidos com o controle do capim-colonião (Panicum maximum Jacq.) nos primeiros 100 a 120 dias. As plantas de eucalipto que conviveram com períodos superiores a 84 dias apresentaram redução de produção de madeira de até $67 \%$ aos 22 meses de idade e $50 \%$ aos 32 meses. A análise de custo benefício, realizada pelo autor, revelou que uma capina manual logo no início da 
instalação da cultura com duas subseqüentes aplicações de oxyfluorfen, visando um período residual acima de 100 dias, proporcionou aceitável produção de madeira a um baixo custo, gerando uma relação custo benefício positiva já aos 32 meses de idade da cultura, quando comparada com a testemunha que conviveu na presença das plantas daninhas por 364 dias.

Toledo et al., (1996) constataram que a atividade mais onerosa no primeiro ano de implantação de E. grandis é o controle das plantas daninhas. Nesta pesquisa, o controle do capim-braquiária na entre linha de pantio com quatro capinas manuais representou $30,7 \%$ dos custos totais de implantação, enquanto que o controle químico com glyphosate em três ocasiões representou $17,3 \%$ do total gasto. Esses autores ainda observaram que, de maneira geral, os custos de controle das plantas daninhas totalizaram cerca de $66 \%$ do custo total de implantação da floresta, independente do manejo adotado. 
Tabela 15. Variação do período total de prevenção àinterferência em função das porcentagens de redução em altura, D.A.P., volume de madeira e I.M.A. das plantas de eucalipto toleradas.

\begin{tabular}{|c|c|c|c|c|c|c|c|c|c|c|c|c|c|c|c|}
\hline \multirow{2}{*}{$\begin{array}{l}\% R \\
P T P I\end{array}$} & \multicolumn{5}{|c|}{ ALTURA } & \multicolumn{4}{|c|}{ D.A.P. } & \multicolumn{3}{|c|}{ Volume } & \multicolumn{3}{|c|}{ I.M.A. } \\
\hline & 12 & 24 & 36 & 48 & 78 & 24 & 36 & 48 & 78 & 36 & 48 & 78 & 36 & 48 & 78 \\
\hline $2 \%$ & 364 & 194 & 188 & 88 & 155 & 242 & 208 & 224 & 134 & 153 & 99 & 92 & 155 & 94 & 90 \\
\hline $5 \%$ & 356 & 166 & 130 & 54 & 133 & 200 & 153 & 150 & 119 & 142 & 91 & 78 & 140 & 85 & 78 \\
\hline PAI & 12 & 24 & 48 & 48 & 78 & 24 & 36 & 48 & 74 & 36 & 48 & 78 & 36 & 48 & 78 \\
\hline $2 \%$ & 6 & 98 & 69 & \#\# & $\# \#$ & 95 & \#\# & \#\# & $\# \#$ & \#\# & $\# \#$ & $\# \#$ & $\# \#$ & \#\# & \#\# \\
\hline $5 \%$ & 12 & 114 & 109 & \#\# & \#\# & 114 & \#\# & \#\# & \#\# & $\# \#$ & \#\# & \#\# & \#\# & \#\# & \#\# \\
\hline PCPI & 12 & 24 & 48 & 48 & 78 & 24 & 36 & 48 & 78 & 36 & 48 & 78 & 36 & 48 & 78 \\
\hline $2 \%$ & 6-364 & $98-194$ & $69-188$ & \#\# & $\# \#$ & $95-242$ & \#\# & \#\# & $\# \#$ & $\# \#$ & \#\# & \#\# & $\# \#$ & $\# \#$ & \#\# \\
\hline $5 \%$ & $12-356$ & $114-166$ & $109-130$ & \#\# & \#\# & $114-200$ & \#\# & \#\# & \#\# & \#\# & \#\# & \#\# & \#\# & \#\# & \#\# \\
\hline
\end{tabular}

${ }^{1}$ Meses após o plantio das mudas de eucalipto. \#\# não avaliado. 
Tabela 16. Efeito dos períodos de controle das plantas daninhas sobre a altura e D.A.P. de plantas de eucalipto.

\begin{tabular}{|c|c|c|c|c|c|c|c|c|c|}
\hline \multirow[b]{2}{*}{ TRAT } & \multicolumn{5}{|c|}{ Altura (m) } & \multicolumn{4}{|c|}{ D.A.P. (cm) } \\
\hline & 12 & 24 & 36 & 48 & 78 & 24 & 36 & 48 & 78 \\
\hline 1 & $3,32 a^{1}$ & $10,95 \mathrm{abcd}$ & $15,30 a b$ & $18,58 \mathrm{abcd}$ & $22,90 \mathrm{a}$ & $10,28 a b c$ & $13,33 \mathrm{a}$ & $14,48 a$ & $16,07 \mathrm{a}$ \\
\hline 2 & $3,08 a b$ & $11,53 a b c$ & $15,45 a b$ & $19,05 \mathrm{abcd}$ & $22,80 \mathrm{a}$ & $10,33 \mathrm{abc}$ & $13,68 \mathrm{a}$ & $15,58 \mathrm{a}$ & $17,24 \mathrm{a}$ \\
\hline 3 & 2,50 abcde & $11,73 a b$ & $15,70 \mathrm{a}$ & $19,60 a b$ & $23,83 \mathrm{a}$ & $11,23 \mathrm{a}$ & $13,75 \mathrm{a}$ & $15,55 \mathrm{a}$ & $17,30 \mathrm{a}$ \\
\hline 4 & 2,06 bcdef & 10,25 abcde & $14,15 a b c$ & $19,10 a b c$ & $24,15 a$ & 9,78 abcd & $13,50 \mathrm{a}$ & $15,95 a$ & $17,19 a$ \\
\hline 5 & 1,82 cdef & 10,78 abcde & $14,38 a b$ & $19,05 \mathrm{abcd}$ & $23,88 \mathrm{a}$ & 9,68 bcde & $13,48 \mathrm{a}$ & $15,88 a$ & $19,50 \mathrm{a}$ \\
\hline 6 & 1,57 def & 9,55 cdef & $14,13 a b c$ & $20,08 a$ & $24,83 \mathrm{a}$ & 9,30 cdef & $14,08 \mathrm{a}$ & $16,85 \mathrm{a}$ & $17,93 \mathrm{a}$ \\
\hline 7 & 1,42 ef & 8,90 defg & $13,65 a b c$ & $18,48 \mathrm{abcd}$ & $22,45 a$ & 8,40 defg & $12,85 \mathrm{a}$ & $14,98 \mathrm{a}$ & $17,51 \mathrm{a}$ \\
\hline 8 & $1,20 \mathrm{f}$ & $6,85 \mathrm{~g}$ & $11,08 \mathrm{~cd}$ & $16,00 \mathrm{~cd}$ & $20,72 \mathrm{a}$ & $6,28 \mathrm{~h}$ & $10,70 a b$ & $13,43 a$ & $12,91 \mathrm{a}$ \\
\hline 9 & $1,16 \mathrm{f}$ & $6,83 \mathrm{~g}$ & $10,30 d$ & $15,65 d$ & $20,63 \mathrm{a}$ & $6,33 \mathrm{~h}$ & $9,25 \mathrm{~b}$ & $12,13 \mathrm{a}$ & $13,74 \mathrm{a}$ \\
\hline 10 & $1,35 \mathrm{f}$ & $7,75 \mathrm{fg}$ & $13,13 \mathrm{abcd}$ & $18,08 \mathrm{abcd}$ & $21,85 a$ & $7,43 \mathrm{gh}$ & $10,98 a b$ & $13,13 a$ & $15,23 a$ \\
\hline 11 & 1,95 cdef & 9,08 def & $14,18 a b c$ & $18,13 \mathrm{abcd}$ & $21,60 \mathrm{a}$ & 8,30 efg & $12,03 a b$ & $13,80 \mathrm{a}$ & $14,54 \mathrm{a}$ \\
\hline 12 & 2,11 bcdef & 9,48 cdef & $13,55 a b c$ & $17,65 \mathrm{abcd}$ & $21,53 \mathrm{a}$ & $8,05 \mathrm{fg}$ & $11,30 a b$ & $13,10 \mathrm{a}$ & $13,58 a$ \\
\hline 13 & 2,18 bcdef & 9,73 bcdef & $14,48 a b$ & $18,78 \mathrm{abcd}$ & $23,40 \mathrm{a}$ & 8,90 cdef & $12,25 a b$ & $14,28 \mathrm{a}$ & $16,71 \mathrm{a}$ \\
\hline 14 & 2,19 bcdef & 8,73 efg & $12,33 \mathrm{bcd}$ & $16,60 \mathrm{bcd}$ & $21,10 \mathrm{a}$ & 8,23 efg & $11,08 a b$ & $12,93 \mathrm{a}$ & $14,27 \mathrm{a}$ \\
\hline 15 & $2,55 \mathrm{abcd}$ & 10,68 abcde & $15,25 a b$ & $20,13 a$ & $24,28 a$ & $9,88 \mathrm{abcd}$ & $13,28 \mathrm{a}$ & $15,20 \mathrm{a}$ & $17,83 a$ \\
\hline 16 & $2,67 a b$ & $12,38 \mathrm{a}$ & $16,25 \mathrm{a}$ & $20,95 a$ & $24,08 \mathrm{a}$ & $10,93 a b$ & $14,10 \mathrm{a}$ & $14,92 \mathrm{a}$ & $17,28 \mathrm{a}$ \\
\hline $\mathrm{F}$ & 11,40 ** & 15,25 ** & 6,86 * & 4,82 * & $1,77 \mathrm{~ns}$ & 26,98 ** & $4,50^{* *}$ & 2,05 * & $1,85 \mathrm{~ns}$ \\
\hline DMS & 1,0911 & 2,1649 & 3,1906 & 3,43 & 5,2851 & 1,4675 & 3,4852 & 4,76 & 8,1784 \\
\hline CV \% & 13,04 & 8,71 & 8,92 & 7,24 & 9,06 & 6,40 & 10,90 & 12,78 & 16,49 \\
\hline
\end{tabular}

1 Médias seguidas de mesma letra não diferem significativamente entre si pelo Teste de Tukey a $1 \%$ de probabilidade; n.s. não significativo; ${ }^{*}$ Significativo a $1 \%$ de probabilidade. 
Tabela 17. Efeito dos períodos de controle das plantas daninhas sobre o volume $\left(\mathrm{m}^{3}\right.$.ha $\left.{ }^{-1}\right)$ e incremento médio anual de madeira $\left(\mathrm{m}^{3}\right.$.ha $\left.\mathrm{a}^{-1} \cdot \mathrm{ano}^{-1}\right)$ de plantas de eucalipto.

\begin{tabular}{|c|c|c|c|c|c|c|}
\hline \multirow[b]{2}{*}{ TRAT } & \multicolumn{3}{|c|}{ Volume de Madeira $\left(\mathrm{m}^{3} \cdot \mathrm{ha}^{-1}\right)$} & \multicolumn{3}{|c|}{ I.M.A. $\left(\mathrm{m}^{3} \cdot\right.$ ha $\left.^{-1} \cdot \mathrm{ano}^{-1}\right)$} \\
\hline & 36 & 48 & 78 & 36 & 48 & 78 \\
\hline 1 & $142,24 \mathrm{ab}$ & $219,99 a b c$ & $371,18 \mathrm{abc}$ & $45,89 a b$ & $53,67 a b$ & $57,13 a b c$ \\
\hline 2 & 189,63 a & 307,03 a & $518,85 \mathrm{a}$ & $61,18 \mathrm{a}$ & $74,88 a b$ & 79,85 a \\
\hline 3 & $154,22 \mathrm{ab}$ & $248,93 a b$ & $398,20 a b c$ & $49,74 a b$ & $60,72 a b$ & $61,28 \mathrm{abc}$ \\
\hline 4 & $115,78 \mathrm{abc}$ & $211,27 \mathrm{abc}$ & $384,03 \mathrm{abc}$ & $37,35 \mathrm{abc}$ & 95,93 a & $59,05 \mathrm{abc}$ \\
\hline 5 & $134,47 a b$ & $250,34 a b$ & $457,63 \mathrm{abc}$ & $43,39 a b$ & $61,07 \mathrm{ab}$ & $70,38 \mathrm{abc}$ \\
\hline 6 & $125,07 a b$ & $251,54 a b$ & $474,35 a b$ & $40,35 a b$ & $61,35 a b$ & $72,98 a b$ \\
\hline 7 & $122,85 a b$ & $226,64 a b$ & $416,85 a b$ & $39,64 a b$ & $55,58 \mathrm{ab}$ & $63,85 a b$ \\
\hline 8 & $36,04 \mathrm{c}$ & $85,17 \mathrm{c}$ & $201,60 \mathrm{c}$ & $11,64 \mathrm{c}$ & $20,78 \mathrm{~b}$ & $28,70 \mathrm{c}$ \\
\hline 9 & $36,3 \mathrm{c}$ & $84,49 \mathrm{c}$ & $212,30 \mathrm{bc}$ & $11,73 \mathrm{c}$ & $20,64 \mathrm{~b}$ & $32,70 \mathrm{bc}$ \\
\hline 10 & $80,43 \mathrm{bc}$ & $158,38 \mathrm{bc}$ & $283,10 a b c$ & 25,94 bc & $39,47 \mathrm{~b}$ & $43,53 a b c$ \\
\hline 11 & $120,24 a b c$ & $210,18 a b c$ & $363,95 a b c$ & $38,79 a b c$ & $51,28 a b$ & $56,00 \mathrm{abc}$ \\
\hline 12 & 104,25 bc & $187,18 \mathrm{abc}$ & $319,58 \mathrm{abc}$ & $33,63 \mathrm{bc}$ & $45,67 a b$ & $49,18 \mathrm{abc}$ \\
\hline 13 & $123,01 a b$ & $220,64 a b c$ & $392,45 a b c$ & $39,69 a b$ & $53,82 a b$ & $60,53 a b c$ \\
\hline 14 & $90,04 \mathrm{bc}$ & $170,27 a b c$ & $303,65 a b c$ & 29,09 bc & $41,53 a b$ & $46,70 \mathrm{abc}$ \\
\hline 15 & $162,34 \mathrm{ab}$ & $281,30 a b$ & $485,65 a b$ & $52,38 a b$ & $68,62 \mathrm{ab}$ & $74,73 a b$ \\
\hline 16 & $192,15 \mathrm{a}$ & $310,08 \mathrm{a}$ & $488,50 \mathrm{a}$ & $61,99 a$ & $75,03 a b$ & $75,15 a$ \\
\hline$F$ & $7,41^{* *}$ & $5,86^{* *}$ & $3,34^{* *}$ & $7,41^{* *}$ & $3,12^{* *}$ & $3,34^{* *}$ \\
\hline DMS & 169,9985 & 280,4441 & 549,2788 & 54,8325 & 112,8037 & 42,26 \\
\hline CV \% & 27,50 & 25,57 & 28,31 & 27,50 & 39,99 & 28,31 \\
\hline
\end{tabular}

1 Médias seguidas de mesma letra não diferem significativamente entre si pelo Teste de Tukey a $1 \%$ de probabilidade; n.s. não significativo; ${ }^{* \star}$ Significativo a $1 \%$ de probabilidade. 


\subsection{Conclusões}

Pelos resultados obtidos nesta pesquisa, pode-se concluir que:

No município de Piratininga, SP, é necessário um período de 78 dias de controle para obter apenas $5 \%$ de redução em volume de madeira aos 78 meses, o que sugere que a determinação do período total de prevenção à interferência (PTPI) deverá ser o mais próximo possível da realização da colheita da cultura. 


\section{CONCLUSÕES GERAIS}

Pelos resultados obtidos nestas pesquisas, pode-se concluir que:

a) A faixa fixa de controle de $50 \mathrm{~cm}$ de cada lado da linha de plantio não foi suficiente para manter as plantas de eucalipto livres da interferência das plantas daninhas presentes em Três Lagoas, MS e Brotas, SP. As faixas de controle recomendadas no manejo integrado de plantas daninhas nestas áreas no primeiro ano de desenvolvimento da cultura foram æ̀̀ faixas fixas iguais a $100 \mathrm{~cm}$ ou crescentes superiores a $50 \mathrm{~cm}$ de cada lado da linha de plantio.

b) No município de Três Lagoas, MS, é necessário um período de 180 dias de controle para obter apenas $5 \%$ de redução em volume de madeira aos 50 meses, o que sugere que a determinação do período total de prevenção à interferência (PTPI) deverá ser o mais próximo possível da realização da colheita da cultura.

c) O PTPI recomendado para o município de Brotas, SP é de 34 dias, considerando o índice de 5\% de redução em volume de madeira aos 48 meses, período no qual a interferência foi significativa.

d) No município de Piratininga, SP, é necessário um período de 78 dias de controle para obter apenas $5 \%$ de redução em volume de madeira aos 78 meses, o que sugere que a determinação do período total de prevenção à interferência (PTPI) deverá ser o mais próximo possível da realização da colheita da cultura. 
e) O primeiro ano de desenvolvimento da cultura do eucalipto é o período mais sensível a interferência das plantas daninhas. No entanto existe a possibilidade de recuperação das plantas de eucalipto aos efeitos da interferência das plantas daninhas a partir dos 22 meses após o plantio. 


\section{REFERÊNCIAS BIBLIOGRÁFICAS}

AHIMANA, C.; MAGHEMBE, J.A. Growth and biomass production by young Eucalyptus terticornis under Agroforestry of Morogo, Tanzania. Forest Ecology and Management, v.22, n.3 - 4, p.219-228, 1987.

ALLAN, E.; TIARKS, E.; HAYMOND, J.D. Pines taeda I. response to fertilization, herbaceus plant control and woody plant control. Forest Ecology and Management, v.14, p.103-112, 1986.

ALVES, P.L.C.A. Estudo das propriedades alelopáticas de espécies de Eucalyptus spp e sua potencialidade no manejo de plantas daninhas. Jaboticabal: FCAV, 1992. 63 p.(Relatório FINEP).

ALVES, P.L.C.A.; TOLEDO, R.E.B.; GUSMAN, A.B. Allelopathic potential of Eucalyptus spp. In: NARWAL, S.S. (Ed.) Allelopathy update. New Delhi: Oxford \& IBH Publ., 1999. v.2, p.131 - 148.

ANDRADE, E.D. $O$ eucalipto. 2. ed. Jundiaí: Cia Paulista de Estradas de Ferro, $1961.665 \mathrm{p}$.

BENEDETTI, V. Controle de ervas daninhas em plantações florestais. IPEF, p.16, set/out. 2000. 
BEZUTTE, A.J.; TOLEDO, R.E.B.; ALVES, P.L.C.A.; PITELLI, R.A. Interferência entre Eucalyptus grandis e Brachiaria decumbens na fase inicial de desenvolvimento da planta transplantada no inverno e no verão. In: CONGRESSO BRASILEIRO DE HERBICIDAS E PLANTAS DANINHAS, 19., Londrina, 1993. Resumos. Londrina, 1993. p.61.

BEZUTTE, A.J.; TOLEDO, R.E.B.; PITELLI, R.A.; ALVES, P.L.C.A.; ALVARENGA, S.F.; CORRADINE, L. Efeito de períodos de convivência de Brachiaria decumbens, no crescimento inicial de Eucalyptus grandis e seus reflexos na produtividade da cultura aos 3 anos de idade. In: CONGRESSO BRASILEIRO DA CIÊNCIA DAS PLANTAS DANINHAS, 20., Florianópolis. 1995. Resumos. Florianópolis, 1995. p.250-251.

BLANCO, H.G. A importância dos estudos ecológicos nos programas de controle de plantas daninhas. O Biológico, v.38 n.10, p.343-350, 1972.

BRANDI, R.M.; BARROS, N.F.; CANDICO, J.EF. Comparação de métodos de limpeza na formação de Eucalyptus alba (Blume) Reinw e E. botrioides Sm. Revista Ceres, v.118, n.21, p.427-433, 1974.

BRITO, M.A.R. Manejo de Plantas Daninhas em Áreas de Reflorestamento. In: CONGRESSO BRASILEIRO DA CIÊNCIA DAS PLANTAS DANINHAS, 20., Florianópolis, 1995. Resumos. Florianópolis, 1995. p.92-95.

CARTER, M.C.; HOLT, H.A. Alternative methods of vegetation management for timber production. In: SYMPOSIUM OF HERBICIDES IN FORESTRY, Arlington, Procedings. 1978. Arlington, 1978. p.125-133.

CARTER, G.A. MILLER, J.H.; DAVIES, D.E.; PATTERSON, A.M. Effect of negative competition on the moisture and nutrient status of lobloly pine. Canadian Journal of Forest Research, v.24, n.1, p.1-9, 1984.

CHARUDATTAN, R.; PITELLI, R.A. Controle biológico de plantas daninhas através de fitopatógenos. Jaboticabal, FUNEP.1993. 34p. 
CHINGAIRE, T.M. Early growth of Eucalyptus camaldulensis under agroforestry conditions at Mafiga, Morogo, Tanzania. Forest Ecology and Management, v.11, p.241-244, 1985.

CHRISTOFFOLETI, P.J.; BRANCO, E.F.; COELHO, J.V.G.; BRITVA, M.; GIMENES FILHO, B. Controle de plantas daninhas em Pinus taeda através do herbicida imazapyr. Circular Técnica IPEF, n.187, 1998.

CHRISTOFFOLETI, P.J.; PASSINI, T. Modelagem das Interações competitivas entre plantas daninhas $\mathrm{x}$ cultivadas. In: CONGRESSO BRASILEIRO DA CIÊNCIA DAS PLANTAS DANINHAS, 22., Foz do Iguaçu. Palestras. Foz do Iguaçu, 2000. p.1-45.

COSTA, A.G.F. Efeito da densidade de plantas de Spermacoce latifolia Aubl. e de Commelina benghalensis L. sobre o crescimento inicial de Eucalyptus grandis W. Hill ex Maiden. Jaboticabal, 1999, 56p. Monografia (Graduação). Faculdade de Ciências Agrárias e Veterinárias, Universidade Estadual Paulista "Júlio de Mesquita Filho".

CROMER,N.R. Perennial weed in australian forests. In: VISTORIAN WEED CONFERENCE, 2., Melbourne, 1973. Melbourne, 1973. p.10-21.

DAVIES, R.J. Tree and weeds: Control for suscefull tree stablishment. London: HMSO, 1987. 36p.

DEUBER, R. Ciência das plantas infestantes: manejo. Campinas, 1997. v.2, 285p.

DINARDO, W. Efeito da densidade de Brachiaria decumbens Stapf e de Panicum maximum Jacq. sobre o crescimento inicial de Eucalyptus grandis W. Hill ex Maiden. Jaboticabal, 1996. 92p. Monografia (Graduação) - Faculdade de Ciências Agrárias e Veterinárias, Universidade Estadual Paulista "Júlio de Mesquita Filho".

DINARDO, W.; TOLEDO, R.E.B.; ALVES, P.L.C.A.; GALLI, A.J.B. Interferência da palhada de capim-braquiária, sobre o crescimento inicial de eucalipto. Planta Daninha, v.16, n.1, p.13-23, 1998. 
DONALD, C.M. Competition among crop and pasture plants. Advances in Agronomy, v.15, p.1-118, 1963.

ELLIS, R.C. et al., The effects of weed competition and nitrogen on the growth of seedlings of Eucalyptus delegatensis in highland area of Tasmania. Australian Forest Research, v.15, n.4, p.395-408, 1985.

FERREIRA, J.E.F. Patologia florestal: principais doenças florestais no Brasil. Viçosa: Sociedade de Investigações Florestais, 1989. 570p.

FERREIRA, J.E.F. Herbicidas em florestas. Boletim Informativo, IPEF, n.5, p.262341, 1977.

FITZGERALD, C.H.; SELDEN, C.W. Herbaceous weed control accelerates growth in a young yellow poplar plantation. Journal of Forestry. v.73, n.1, p.2, 1975.

FOLONI, L.L. Avaliação do desempenho de pulverização simultânea de glyphosate e oxyfluorfen em Eucalyptus. In: CONGRESSO ALAM, 11., Vieña Del Mar, 1992. Resumos. Vieña Del Mar, 1992. p.12.

FUERST, E.P., PUTNAM, A.R. Separating the competitive and allelopathic components of interference: Theoretical Principles. Journal Chemical of Ecology, v.9, p.937-944, 1983.

GALLI, F. Manual de fitopatologia . São Paulo: Agronômica Ceres, 1980. 600p. GARLIPP, R.B. Oferta e demanda de madeira de florestas plantadas. In: WORKSHOP: MADEIRA E MOBILIÁRIO - FEMADE, Curitiba, 2000. Palestras. Curitiba, 2000.

GONÇALVES, J.L.M.; STAPE, J.L.; BENEDETTI, V.; FESSEL, V.A.G.; GAVA, J.L. Reflexos do cultivo mínimo e intensivo do solo em sua fertilidade e na nutrição das árvores. In: GONÇALVES, J.L.M.; BENEDETTI, V. (Ed.) Nutrição e fertilização florestal. Piracicaba: IPEF, 2000. 427p.

GROVE, T.S. Growth response of trees and understory to applied nitrogen and phosphorus in karri (Eucalyptus diversicolor) forest. Forest Ecology and Management, v.23, p.87-103, 1988. 
HALLIGAN, J.P. Toxicity of Artemisia california to associated herb species. Am. Midl. Nat, v.95, p.406-421, 1976.

HARPER, J.L. Population biology of plants. New York: Academic Press, 1977. 892p.

HOLLIS, C.A.; SMITH, J.E.; FISCHER, R.F. Allelopathic effects of common understory species on germination and growth of sowthern pines. Forest Science, v.28, p.509-515, 1982.

IPEF (Instituto de Pesquisa e Estudos Florestais). Tratos culturais, controle de ervas daninhas. Circular Técnica IPEF, 7p, 1976.

KISSMANN, K.G. Plantas infestantes e nocivas. São Paulo: BASF Brasileira, 1992. t. 2, 798p.

KOGAN, M.A. Malezas; ecofisiologia y estratégias de control. Santiago: Pontificia Universidad Catolica, 1992. 402p.

KOGAN, M.A., OLATE, E.; FIGUEROA,R. Período critico de control de malezas en establecimento del eucalipto. In: CONGRESSO LATINOAMERICANO DE MALEZAS, 12., Montevideo, 1995, Resumos, Montevideo, 1995. 136p.

KOGAN, M.A. Interferencia de las malezas en plantaciones forestales y estratégias de control. In: AVANCES EN MANEJO DE MALEZAS EN PRODUCION AGRICOLA Y FORESTAL. Santiago, 1992. Resumos, Santiago, 1992. p.119.

KROPFF, M.J.; VAN LAAR, H.H. Modelling crop-weed interactions. Manila: International Rice Research Institute. 1993. 274p.

LABRADA, R.; CASALEY, J.C.; PARKER, C. Weed management for developing countries. Rome: FAO, 1994. 120p.

LAMB, D. Weed control in tropical forest plantation using glyphosate. Pans, v.21, p.177-181, 1975.

LIMA, W. O impacto ambiental do eucalipto. 2.ed. São Paulo: EDUSP, Universidade de São Paulo, 1996. 301p.

MARCHI, S.R. Estudos básicos das relações de interferência entre plantas daninhas e plantas de eucalipto. Jaboticabal, 1989. 57p. Monografia 
(Graduação) - Faculdade de Ciências Agrárias e Veterinárias, Universidade Estadual Paulista "Julio de Mesquita Filho".

MARCHI, S.R. Efeitos de períodos de convivência e de controle das plantas daninhas sobre o crescimento inicial e a composição mineral de Eucalyptus grandis W. Hill ex Maiden. Jaboticabal, 1996. 94p. Dissertação (M.S.) Faculdade de Ciências Agrárias e Veterinárias, Universidade Estadual Paulista "Julio de Mesquita Filho".

MARCHI, S.R.; PITELLI, R.A.; BEZUTTE, A.J.; CORRADINE, L.; ALVARENGA, S.F. Efeito de períodos de convivência e de controle das plantas daninhas na cultura do Eucalyptus grandis. In: SEMINÁRIO SOBRE CULTIVO MíNIMO DO SOLO EM FLORESTAS, 1., Curitiba, 1995. Anais. Curitiba, 1995. p.122-133.

MENDES, J.E.P; DOS ANJOS, N.; CAMARGO, F.R.A. Monitoramento do besouroamarelo. Folha Florestal, n.91, p.1-9, maio/jun. 1998.

MC NABB, K. Chemical vegetation management in reforestation areas. In: CONGRESSO BRASILEIRO DA CIÊNCIA DAS PLANTAS DANINHAS, 21., Caxambu, 1997. Palestras. Caxambu, 1997. p.37-50.

NAMBIAR, E.K.S. Effects of compaction and simulated root channels in the subsoil on root development, water uptake and growth of Pinus radiata. Tree Physiology, v.10, n.3, p.297 - 306, 1992.

NORBY, R.J.; KOZLOWSKI, T.T. Allelopathic potential of ground cover species on Pinus resinosa seedlings. Plant Soil, v.57, p.363-374, 1980. 
OSSE, L. As culturas de eucaliptos da Cia Siderurgica Belgo Mineira. Anais Brasileiros Economia Florestal. v.13, p.102-112, 1961.

PITELLI, R.A. Interferência das plantas daninhas nas culturas agrícolas. Informe Agropecuário, v.11, n.29, p.16-27, 1985.

PITELLI, R.A. Competição e controle das plantas daninhas em áreas agrícolas. In:

SEMINÁRIO TÉCNICO SOBRE HERBICIDAS EM REFLORESTAMENTOS. Piracicaba, 1986. Série Técnica - IPEF, v.4, n.12, p.25-35, 1987.

PITELLI, R.A.; DURIGAN, J.C. Terminologia para períodos críticos de controle e de convivência das plantas daninhas em culturas anuais e bianuais. In: CONGRESSO BRASILEIRO DE HERBICIDAS E PLANTAS DANINHAS, 15., Belo Horizonte, 1984. Resumos. Belo Horizonte, 1984. p.37.

PITELLI, R.A.; KARAM, D. Ecologia de plantas daninhas e a sua interferência em culturas florestais. In: SEMINÁRIO TÉCNICO SOBRE PLANTAS DANINHAS E O USO DE HERBICIDAS EM REFLORESTAMENTO, 1., Rio de Janeiro, 1988. Anais. Rio de Janeiro, 1988. p.44-64.

PITELLI, R.A.; MARCHI, S.R. Interferência das plantas invasoras nas áreas de reflorestamento. In: SEMINÁRIO TÉCNICO SOBRE PLANTAS DANINHAS E O USO DE HERBICIDAS EM REFLORESTAMENTO, 3., Belo Horizonte 1991. Anais. Belo Horizonte, 1991. p.1-11.

PITELLI, R.A.; RODRIGUES, J.J.V.; KARAM, D.; COELHO, J.P.; ZANUNCIO, I; ZANUNCIO, C.C. Efeitos de períodos de convivência e do controle de plantas daninhas na cultura de Eucalyptus. In: SEMINÁRIO TÉCNICO SOBRE PLANTAS DANINHAS E O USO DE HERBICIDAS EM REFLORESTAMENTO, 1., Rio de Janeiro, 1988. Anais. Rio de Janeiro, 1988. p.110-123.

PORCILE, J.F; DIAZ, E.D; TAMOSIUNAS, M.; AMARO, C. Importância de las malezas en produccion florestal. In: CONGRESSO LATINOAMERICANO DE MALEZAS, 12., Montevideo, 1995. Resumos. Montevideo, 1995. p.137. 
PRASSAD, R. Biological control of weeds in reforestation areas. In: CONGRESSO DA BRASILEIRO DA CIÊNCIA DAS PLANTAS DANINHAS, 21., Caxambu, 1997. Palestras. Caxambu, 1997. p.51-57.

PROTIL, C.Z. Crescimento e composição mineral de Eucalyptus urophylla S.T. submetido à interferência de plantas da ninhas. Viçosa, 1992, 64p. Dissertação (M.S.) - Universidade Federal de Viçosa.

RICE, E.L. Allelopathy. 2 ed. New York: Academic Press, 1974. 422p.

RODRIGUES, J.J.V.; COLEHO, J.P; PITELLI, R.A. Efeitos de períodos de controle de convivência do capim-colonião (Panicum maximum Jaqc.) na cultura do Eucalyptus. In: SEMINÁRIO TÉCNICO SOBRE PLANTAS DANINHAS E O USO DE HERBICDAS EM REFLORESTAMENTO, 3., Belo Horizonte, 1991. Anais. Belo Horizonte, 1991. p.43-54.

SANDS, R. ; NAMBIAR, E.K.S. Water relations of Pinus radiata in competition with weeds. Canadian Journal of Forest Research, v.14, n.2, p.233-237, 1984.

SOCIEDADE BRASILEIRA DE SILVICULTURA. Silviculture-se. http: www.sbs.gov.br. (14 de dezembro de 2001).

SHAW, W.C. Integrated weed management systens tecnology for pest management. Weeds, v.30, supl. 1, p.2-12, 1956.

SILVA, C.R.; GONÇALVES, J.L.M.; FOLEGATTI, B.S.; STAPE, J.L.; GAVA, J.L. Infestação de plantas invasoras em povoamentos de eucalipto estabelecidos nos sistemas de cultivo mínimo e intensivo do solo. In: CONFERÊNCIA DA I IUFRO SOBRE SILVICULTURA E MELHORAMENTO DE EUCALIPTOS, Salvador, 1997. Anais. Salvador, 1997. v.3. p.234-241.

SILVA, J.R. Efeito da faixa de controle de plantas daninhas no desenvolvimento inicial de Eucalyptus grandis W. Hill ex Maiden. Jaboticabal, 1999. 79p. Monografia (Graduação) - Faculdade de Ciências Agrárias e Veterinárias. Universidade Estadual Paulista. "Júlio Mesquita Filho". 
SILVA, W.; SILVA, A.A.; FERREIRA, F.A.; SEDIYAMA, T. Interferência de Brachiaria brizanta sobre Eucalyptus grandis e E. citriodora cultivadas em vasos em três níveis de água. In: CONGRESSO BRASILEIRO DA CIÊNCIA DAS PLANTAS DANINHAS, 20., Florianópolis, 1995. Resumos. Florianópolis, 1995. p.287-288.

SILVA, W.; SILVA, J.F.; CARDOSO, A.A.; BARROS, N.F. Tolerância de Eucalyptus spp. a diferentes herbicidas. Árvore, v.18, n.3, p.287-300, 1994.

SIMÕES, J.W. Reflorestamento e manejo de florestas implantadas. Documentos Florestais, n. 4, p.1-29, set., 1989.

SMETHURST, P.M. Weed effects on early $\mathrm{K}$ and $\mathrm{P}$ nutrition and growth of slash pine on a Spodosol. Forest Ecology and Management, v.60, n.1/2, p.15 - 26, 1993.

SOUTH, D.B.; ZWOLINSKI, J.B.; ALLEN, H.L. Economic returns from enhancing lobloly pine establishment fertilization, hexazinone, and intensive soil cultivation. New Forest. v.10, p. 239-256, 1995.

SOUZA, L.S. VELINI, E.D., MAIOMI-RODELLA, R.C.S. Avaliação do efeito alelopático de 18 espécies de plantas daninhas sobre o crescimento inicial de Eucalyptus grandis. In: CONGRESSO BRASILEIRO DE HERBICIDAS E PLANTAS DANINHAS, 19., Londrina ,1993, Resumos. Londrina, 1993, p.25.

STAPE, J.L. Definição do período e localização de cobertura de Eucalyptus grandis em função da dinâmica do crescimento radicular. Circular Técnica IPEF, n.174, p1-2. 1990.

TOLEDO, R.E.B. Efeitos da faixa de controle e dos períodos de controle e de convivência de Brachiaria decumbens Stapf no desenvolvimento inicial de plantas de Eucalyptus urograndis. Piracicaba, 1998. 71p. Dissertação (Mestrado) - Escola Superior "Luiz de Queiroz". Universidade de São Paulo. 
TOLEDO, R.E.B. Faixa e período de controle de plantas daninhas em áreas Florestais (compact disc). In: SEMINÁRIO SOBRE CONTROLE DE PLANTAS INFESTANTES EM ÁREAS FlORESTAIS, 1., Piracicaba, 1999. Piracicaba: IPEF, 1999.

TOLEDO, R.E.B., ALVES, P.L.C.A.; VALLE, C.; ALVARENGA, S.F. Comparação dos custos de quatro métodos de manejo de Brachiaria decumbens Stapf em área de implantação de Eucalyptus grandis W. Hill ex Maiden. Árvore, v.20, n.3, p.319-330, 1996.

TOLEDO, R.E.B.; ALVES, P.L.C.A.; PITELLI, R.A.; VALLE, C.; ALVARENGA, S.F. Manejo de Brachiaria decumbens em área reflorestada com Eucalyptus grandis e seu reflexo no crescimento da cultura". Scientia Florestalis, n.57, p.130-141. jun. 2000a.

TOLEDO, R.E.B.; VICTORIA FILHO, R.; PITELLI, R.A.; ALVES, P.L.C.A.; LOPES, M.A.F. Efeitos de períodos de controle de plantas daninhas sobre o desenvolvimento inicial de plantas de eucalipto. Planta Daninha, v.18, n.3, p.395-404. 2000b.

TOLEDO, R.E.B.; VITORIA FILHO, R.; ALVES, P.L.C.A.; PITELLI, R.A.; CADINI, M.T. Efeitos da faixa de controle do capim-braquiária (Brachiaria decumbens) no desenvolvimento inicial de plantas de eucalipto. Planta Daninha, v.18, n.3, p.383-393. 2000c.

VELINI, E.D. Comportamento de herbicidas no solo: In: CONGRESSO DE PLANTAS DANINHAS EM OLERICOLAS, Botucatu, 1992,. Anais. Botucatu, 1992, p.105-128. 1992.

VICTORIA FILHO, R. Estratégias de manejo de plantas daninhas. In: ZAMBOLIM, L. (Ed.) Manejo integrado: doenças, pragas e plantas daninhas. Viçosa: UFV, Depto de Fitopatologia, 2000. 416p. 
WIETCHETEK, M. Aplicação e resultados de GOAL-BR no controle de plantas daninhas em Pinus. In: SEMINÁRIO TÉCNICO SOBRE PLANTAS DANINHAS E O USO DE HERBICIDAS EM REFLORESTAMENTO, 1., Rio de Janeiro, 1988. Anais. Rio de Janeiro, 1988. p.205-225.

ZEN, S. Influência da matocompetição em plantas de Eucaltyptus grandis. IPEF Série Técnica, n.12, p.25-35, 1987.

ZUTTER, B.R.; GROVER, G.R.; GJERSTAD, D.H. Effects of herbaceous weed control using herbicides on a young lobloly pine plantation. Forest Science ${ }_{2}$ v.32, n.4, p.882-899, 1986. 